NBER WORKING PAPER SERIES

WHY IS THERE MORE CRIME

IN CITIES?

Edward L. Glaeser

Bruce Sacerdote

Working Paper 5430

NATIONAL BUREAU OF ECONOMIC RESEARCH 1050 Massachusetts Avenue

Cambridge, MA 02138

January 1996

This paper was written for the Fraser Institute Conference for Gary Becker's 65th birthday. Both authors thank the National Science Foundation for financial support. The second author thanks the Jacob K. Javits Fellowship program. Helpful comments and discussions were provided by David Cutler, Benjamin Friedman, Steven Levitt and Richard Posner. This paper is part of NBER's research program in Labor Studies. Any opinions expressed are those of the authors and not those of the National Bureau of Economic Research.

() 1996 by Edward L. Glaeser and Bruce Sacerdote. All rights reserved. Short sections of text, not to exceed two paragraphs, may be quoted without explicit permission provided that full credit, including $\mathcal{C}$ notice, is given to the source. 


\title{
WHY IS THERE MORE CRIME
}

IN CITIES?

\begin{abstract}
Crime rates are much higher in big cities than in either small cities or rural areas, and this situation has been relatively pervasive for several centuries. This paper attempts to explain this connection by using victimization data, evidence from the NLSY on criminal behavior and the Uniform Crime Reports. Higher pecuniary benefits for crime in large cities can explain approximately $27 \%$ of the effect for overall crime, though obviously much less of the urbancrime connection for non-pecuniary crimes such as rape or assault. Lower arrest probabilities, and lower probability of recognition, are a feature of urban life, but these factors seem to explain at most $20 \%$ of the urban crime effect. The remaining $45-60 \%$ of the effect can be related to observable characteristics of individuals and cities. The characteristics that seem most important are those that reflect tastes, social influences and family structure. Ultimately, we can say that the urban crime premium is associated with these characteristics, but we are left trying to explain why these characteristics are connected with urban living.
\end{abstract}

Edward L. Glaeser

Department of Economics

113 Littauer Center

Harvard University

Cambridge, MA 02138

and NBER
Bruce Sacerdote

Department of Economics

Harvard University

Cambridge, MA 02138 


\section{Introduction}

According to the 1994 Statistical Abstract of the United States, metropolitan statistical areas (MSAs) have 18\% more crime than other American cities and $200 \%$ more crime than rural areas. ${ }^{1}$ For violent crimes, MSAs have $79 \%$ more crime than urban areas not in MSAs and almost 300\% more crime than rural areas. New York and Los Angeles have crime rates that are approximately four times higher than the crime rates of metropolitan statistical areas as a whole and have violent crime rates that are more than 2.5 times the violent crime rates of all MSAs. Figure 1 shows the correlation between crime rates per capita and log of population for cities in the United States-- city size can explain $12 \%$ of the variation in cross city crime rates.

As we discuss later in Section III, these numbers are not merely the result of reporting biases. Figure 2 shows the correlation between murder rates and log of population. The connection between city size and murder is stronger than the connection between crime generally and city size, and it is generally thought that murder rates are free of reporting biases. Victimization surveys show a comparable relationship between crime and city size. Our victimization results show that the probability that an individual in 1989 has been victimized (i.e. has had any crime perpetrated against him) is $21.7 \%$ if that individual lives in a city of more than $1,000,000$ people. The comparable figure for cities with between 1 and 10 thousand inhabitants is $9.4 \% .{ }^{2}$

Of course, the connection between crime and city size is hardly a new fact. Criminologists have discussed the urban tendency towards crime for decades (see, e.g., Larson, 1984, Flango and Sherbonou, 1976 or two separate articles in Radzinowicz and Wolfgang, 1977). Wirth (1938) discusses the observed connection between crime and urbanization, and argues that this connection is evidence for his theory of "urbanism as a way of life." In fact, going even further back in time, social observers have for centuries assailed cities for their supposed concentration of immoral activity. Jefferson wrote that "I view cities as pestilential to the morals, the health, the liberties of man," and Rousseau claimed that "cities are the abyss of the human species." Lane

\footnotetext{
1 These data are ultimately derived from the FBI Uniform Crime Reports.

${ }^{2}$ These results are taken from Table $1 \mathrm{C}$ regression 1.
} 
(1979) documents that at least in the 19th century, the crime rate in at least one city was high enough to justify the comments of such observers.

In fact, the connection between cities and crime is both so strong in the U.S. and so much a part of our history that it becomes almost impossible to remember that in many times and in many places cities are places of safety, not of danger. The low urban crime rates of Japan and Switzerland make it obvious that under different social conditions, density can lead to social control and limited crime. Many medieval cities were built in part to protect their inhabitants from thieving bandits and noblemen (Pirenne, 1929). Ideally, the cases where urbanization is not linked to crime should provide us with information about what conditions in the United States today create the strong correlation between city size and crime, but since we are restricting our attention to current, U.S. data, we will be limited to examining data where city size and crime are tightly linked.

There is a litany of theory about the connection between cities and crime. Indeed, some of the most important of the ideas on this topic were written at the early stages of modern sociology by Emile Durkheim, George Simmel and Max Weber. Wirth (1938) claims that urban crime rates reflect the more anonymous and unstable nature of urban life. Wilson and Herrnstein (1984) also focus on high numbers of temporary urban residents who fear neither recognition nor community reprisals. Milgram (1970) claims that cities create an informational overload that leads bystanders to avoid involvement in crimes against their neighbors. Jacobs (1961) focuses on the emptiness of urban streets, and argues that cities only abet crimes when urban neighborhoods lose (as they often do) their traditional social structures.

This paper attempts to test a variety of theories about the correlation between crime and urban size. We will decompose the observed connection between cities and crime into four categories: (1) higher pecuniary returns to crime in urban areas, (2) lower probability of arrest or being recognized in urban areas, (3) characteristics that affect crime (primarily by lowering returns in the legal sector) that are exogenous with respect to location but that happen to be correlated with urban status, and (4) characteristics that are endogenous with respect to location that both cause crime and are caused by urban status-- these 
endogenous variables may effect crime through social influences and the development of tastes or ethical strictures. ${ }^{3}$ Ideally, empirical work in this area could both show that there are more crimes per capita because crimes have higher value on average in cities, and also explain why crimes are more lucrative in cities. We will have some information on the important issue of how cities drive rewards to crime, but primarily our results will focus on the basic decomposition.

We find that approximately $45 \%$ of the urban crime premium in cross-city regressions can be explained by observable characteristics that have both endogenous and exogenous elements. Approximately the same share of the urban crime effect can be explained by observables in victimization regressions. The bulk of this reduction (of the urban coefficient) can be created with demographic variables alone. However, when we include the percent of female headed households in the cross-city crime regressions, we find that that variable completely dominates; the demographics become unimportant once we have controlled for the percent female headed households. Our interpretation is that while more exogenous variables may lie at the root of a substantial share of the connection between cities and crime, these variables do not drive crime directly but rather operate through other variables relating to family structure, social structure and perhaps even the formation of tastes. ${ }^{4}$

Almost $30 \%$ of the urban crime premium can be explained by higher rewards per crime in cities. Both the Uniform Crime Reports and the victimization records show a strong connection between city size and the value of the average crime. The estimates of this connection from the two data sets are also comparable in magnitude. The natural interpretation of this finding is that theft becomes easier as the potential criminal's environment becomes more densely populated with victims. However, it is also possible that this urban value effect is the result of urban criminals taking bigger risks and stealing more valuable objects because either policing is less effective in cities

\footnotetext{
${ }^{3}$ For example cities may increase single motherhood which in turn increases crime.

${ }^{4}$ In fact, race can reduce the connection between city size and crime by $35 \%$ when it is included in the basic regression alone. However, when we include female headed households in this same regression, the race effect flips signs.
} 
or because criminals in cities are more tolerant of risk. Our decompositional framework cannot sort out these alternatives and simply attributes $30 \%$ of the high urban crime rates to high returns to crime in cities.

The results on arrest rates, defined as arrests per reported crime, suggest a mild relationship between city size and the ratio of arrest rates to reported crimes. Cities seem to respond to high crime levels and they have many more policemen per capita than non-urban areas. When we adjust for higher underreporting rates in big cities, we find that there is a mild correlation between city size and arrests per actual crime. That correlation works primarily through less reporting. ${ }^{5}$ Using arrests per reported crime, we find that the arrest rate can explain around $3 \%$ of the urban crime effect. Using arrests per actual crime, we find the arrest rate effect can explain approximately $13 \%$ of the urban crime premium.

The effect of urban anonymity seems to be real and non-urban residents are much more likely to recognize their offender than urban residents. This effect is true even controlling for the type of crimes perpetrated in different types of cities. The effect of anonymity may create the lower reporting rates or less effective policing. It also may create fewer applications of informal community sanctions against criminal behavior. Elsewhere, Jarrell and House (1991) have documented a connection between the number of strangers (tourists, college students) and the level of crime in a location. The relative importance of the anonymity effect can be found only be making estimates about the relative importance of formal versus informal community sanctions. Under the assumption that community sanctions are approximately $25 \%$ of the formal police sanctions for minor crimes (a relatively arbitrary assumption), we find that greater anonymity seems to explain at most $4 \%$ of the urban crime premium.

The residual urban crime effect, which is less than $20 \%$ of the raw effect, can easily be explained with other omitted, particularly endogneous, variables. For example, in the National Longitudinal Survey of Youth, variables such as

\footnotetext{
${ }^{5}$ It works through less reporting in a purely mechanical manner. In a deeper sense, lower reporting rates may themselves be driven by less effective policing and the sense that reports will be less effective in dense urban areas.
} 
marijuana usage, tendencies towards non-criminal violence, church attendance and variables related to patience all are significant in their ability to explain crime. Some of these variables are related to urban residence and controlling for these forces can reduce the urban crime effect in some cases substantially. We do not have these variables in the UCR cross city data, on which our decompositions are based, so the remaining city crime effect may be the result of missing these variables.

However, when we argue that crime seems to be strongly related to urban size because of endogenous forces that are measured with these variables, we are not solving the puzzle of urban pathologies but simply pushing them a step backward. It is true that more than $50 \%$ of the urban crime effect occurs because cities either attract or create crime prone individuals. Nevertheless, we are still at the beginning stages of understanding either the forces that impel migration of the poor to dense urban areas or understanding how urban environments themselves give people tastes or social influences that in turn generate crime.

The next section of the paper presents a simple decomposition for examining the prevalence of crime and discusses the measurement issues when criminals choose their own level of danger. Section III presents the results from the National Crime Victimization Surveys (NCS). Section IV presents results from the National Longitudinal Survey of Youth (NLSY). Section V presents results from the Uniform Crime Reports (UCR) and Section VI concludes.

\section{A Decomposition}

This decomposition attempts to separate the potential causes of the relationship between cities and the level of criminal behavior. In this model, we will intentionally ignore the intensive margin of criminality, i.e. the number of crimes per criminal and assume that this number is fixed at some constant and model only the extensive margin, i.e. the decision to become a criminal. Our decision to avoid this extremely important margin is based primarily on data availability. While sources on crimes per criminal do exist (Chaikin, 1978, or Blumstein and Cohen, 1979), we do not currently have 
access to them and thus have little ability to check any predictions about the number of crimes per criminal or any ability to test whether the urban crime effect is coming through greater crimes per criminal. Thus we restrict ourselves to an individual's choice about whether or not to become a criminal.

Following Becker (1968), individuals commit crimes when the benefits exceed the costs. In general the rule is to commit a crime whenever:

$$
B>\theta+K S+P C,
$$

where $B$ reflects the benefits of crime, $\theta$ are the individual specific costs which occur whether or not the individual is either arrested or incarcerated, $\mathrm{K}$ refers to the probability of being known by one's victim or noticed by the community and $\mathrm{S}$ is the stigma if the individual is identified as a criminal, $\mathrm{P}$ refers to the probability of arrest, $C$ is the cost of arrest and incarceration to the individual. The individual specific costs, $\theta$, can refer to time costs, inconvenience, and the psychic costs of breaking the law. The cost of incarceration will incorporate both the opportunity cost of lost time and also the rate of discount since the time loss is felt only over time.

We assume that the variables $\theta$ and $C$ are functions of $X$, exogenous individual attributes, and $\mathrm{Z}$ which are individual characteristics that are themselves determined by the location. The benefits of crime, the probability of arrest and the probability of facing social stigma are all functions of locational attributes denoted $Y$. The cost of stigma is assumed to be a constant over space. ${ }^{6} \quad \mathrm{~B}$ will be a declining function of the total number of crimes committed (denoted $Q$ ). For simplicity, we assume that all potential criminals in the same location have the same $X$ and $Z$ variables. ${ }^{7}$ Thus the criminal equilibrium will be defined by the following condition:

\footnotetext{
${ }^{6}$ This assumption may be somewhat unrealistic as the amount of social stigma clearly differs across communities. However, we believe that there is little loss in generality if we assume that the punishment meted out across communities is constant but communities differ in their ability or willingness to give out that social punishment.

${ }^{7}$ It is relatively straightforward to allow for heterogeneity across individuals. In that case equation (2) must hold only for the marginal criminal.
} 


$$
B(Y, Q)=\theta(X, Z(Y))+K(Y) S+P(Y) C(X, Z(Y))
$$

We can differentiate (2) to determine the overall forces driving locational connections with crime:

$$
\frac{\partial Q}{\partial Y}=\frac{C}{B_{Q}} P^{\prime}(Y)+\frac{S(Y)}{B_{Q}} K^{\prime}(Y)-\frac{B_{Y}}{B_{Q}}+Z^{\prime}(Y) \frac{\theta_{Z}+P C_{Z}}{B_{Q}}+\frac{d X}{d Y} \frac{\theta_{X}+P C_{X}}{B_{Q}}
$$

The change in quantities of crime over space can come from changing area characteristics. Location specific attributes might (1) change the probability of apprehension (the $\frac{C}{B_{Q}} P^{\prime}(Y)$ term), (2) alter the probability of community punishment (the $\frac{S(Y)}{B_{Q}} K^{\prime}(Y)$ term), and (3) effect the returns from crime (the $-\frac{B_{Y}}{B_{Q}}$ term). Alternatively the community attributes might change the level of location based individual characteristics which could effect the apprehension invariant costs of crime (the $Z^{\prime}(Y) \frac{\theta_{Z}}{B_{Q}}$ ) or the costs of apprehension (the $Z^{\prime}(Y) \frac{P C_{Z}}{B_{Q}}$ term). Examples of these effects might be that social interactions in inner city neighborhoods lead to different ethical attitudes towards crime or different levels of patience. Finally, the community attributes might be correlated with other exogenous individual attributes and these individual attributes might also create lower costs (the $\frac{d X}{d Y} \frac{\theta_{X}+P C_{X}}{B_{Q}}$ term).

Following this equation, we will try split the city-crime connection into four types of explanations: (1) the density and anonymity of cities makes arrest less likely and also social sanctions are less likely to be imposed, (2) cities increase the ability to steal, perhaps particularly from the wealthy, ${ }^{8}(3)$ cities attract different citizens and individual attributes can explain the urban crime

\footnotetext{
${ }^{8}$ It should be stressed that the benefits of crime are taken as given here. In fact criminals face a choice set where the trade off the rewards of crime with the danger of that crime and it is likely that a more safe area will induce criminals to undertake more crime and more lucrative crime.
} 
premium, and (4) cities change individuals' characteristics and lead indirectly to higher crime. Theories (3) and (4) will be hard to distinguish and most of our attempts to separate between them will be relatively coarse.

We will denote the partial elasticity of a variable $A$ with respect to another variable $\mathrm{B}$ as $\varepsilon_{B}^{A}=\frac{B}{A} \frac{\partial A}{\partial B}$. The elasticity of crime with respect to the probability of arrest is:

$$
\varepsilon_{\mathrm{P}}^{\mathrm{Q}}=\frac{\mathrm{P}}{\mathrm{Q}} \frac{\partial \mathrm{Q}}{\partial \mathrm{P}}=\frac{\mathrm{PC}}{\mathrm{QB}_{\mathrm{Q}}}
$$

Using this elasticity, it is possible to rewrite (3) in terms of elasticities. We assume that the relevant $Y$ variable is overall city size and we will denote that $\mathrm{Y}$ variable as $\mathrm{N}$. Thus we can write:

(3') $\varepsilon_{\mathrm{N}}^{\mathrm{Q}}=\varepsilon_{\mathrm{P}}^{\mathrm{Q}} \varepsilon_{\mathrm{N}}^{\mathrm{P}}+\frac{\mathrm{KS}}{\mathrm{PC}} \varepsilon_{\mathrm{P}}^{\mathrm{Q}_{\mathrm{N}}} \varepsilon_{\mathrm{N}}^{\mathrm{K}}-\frac{\mathrm{B}}{\mathrm{PC}} \varepsilon_{\mathrm{P}}^{\mathrm{Q}_{\mathrm{N}}} \varepsilon_{\mathrm{N}}^{\mathrm{B}}+\mathrm{NZ}^{\prime}(\mathrm{N}) \frac{\theta_{\mathrm{Z}}+\mathrm{PC}_{\mathrm{Z}}}{\mathrm{QB}_{\mathrm{Q}}}+\mathrm{N} \frac{\mathrm{dX}}{\mathrm{dN}} \frac{\theta_{\mathrm{X}}+\mathrm{PC}_{\mathrm{X}}}{\mathrm{QB}_{\mathrm{Q}}}$

We will return to this equation at the end of the paper where it will allow us to perform a decomposition of the total elasticity of crime with respect to city size. While we may not know exactly what various parameters are, we will be able to show how much of the overall urban crime effect comes from different sources depending on a different share of assumptions.

\section{An Aside on Criminal's Choice of Danger}

In this subsection, we allow criminals to choose how dangerous their crimes will be by letting the benefits and the probability of arrest both be functions of a choice variable denoted $\phi$, where the benefits of crime are rising in $\phi$ and the probability of arrest is also rising in $\phi$. Criminals will maximize:

$$
\mathrm{B}(\phi, \mathrm{Y})-\theta-\mathrm{K}(\mathrm{Y}) \mathrm{S}-\mathrm{P}(\phi, \mathrm{Y}) \mathrm{C}
$$

which has first order condition 


$$
\frac{\partial \mathrm{B}(\phi, \mathrm{Y})}{\partial \phi}=\mathrm{C} \frac{\partial \mathrm{P}(\phi, \mathrm{Y})}{\partial \phi}
$$

so that the marginal benefits of more dangerous crime are exactly offset by the marginal cost of danger on the additional probability of getting caught. If we differentiate this condition to find the comparative statics, we find:

$$
\frac{\partial \phi}{\partial Y}=\frac{C P_{\phi Y}-B_{\phi Y}}{B_{\phi \phi}-C P_{\phi \phi}}
$$

The denominator of this expression is negative, by assumption to satisfy second order conditions. Consider the case where $B(\phi, Y)=b(N) B(\phi)$ and $P(\phi, Y)=p(N) P(\phi)$, then:

$$
\frac{\partial \phi}{\partial N}=\frac{C P^{\prime}(\phi) p^{\prime}(N)-B^{\prime}(\phi) b^{\prime}(N)}{\left(B_{\phi \phi}-C P_{\phi \phi}\right)} .
$$

If cities act to both increase the benefits of crime $\left(b^{\prime}(N)>0\right)$ and decrease the probability of getting caught $\left(\mathrm{p}^{\prime}(\mathrm{N})<0\right)$, the overall effect on risk taking will be strongly positive. If we then examine the effect of city size on the probability of getting caught:

(9) $\frac{d P(\phi, N)}{d N}=\frac{\partial P}{\partial N}+\frac{\partial P}{\partial \phi} \frac{\partial \phi}{\partial N}=p^{\prime}(N) P(\phi)+p(N) P(\phi) \frac{C P^{\prime}(\phi) p^{\prime}(N)-B^{\prime}(\phi) b^{\prime}(N)}{B_{\phi \phi}-C P_{\phi \phi}}$.

Thus, the observed urban effect on the probability of being caught may understate the true urban effect on probability of arrest (i.e. $\mathrm{p}^{\prime}(\mathrm{N})$ ). Since criminals will compensate by attacking more dangerous targets, the observed connection between cities and arrest rates will include both the first term in (9) which is the term related to cities reducing the probability of arrest and the second term in (9) which relates to the taking on of more danger. One useful implication of equation (9), though, is that if cities only work through the benefit level, we will see higher arrest rates in cities. Thus, if we see lower arrest rates there is little ambiguity and that these arrest rates are in fact measuring a less effective policing regime. 
Alternatively, if we examine the connection between cities and the average benefit level of crime, we find:

$$
\frac{d B(\phi, N)}{d N}=\frac{\partial B}{\partial N}+\frac{\partial B}{\partial \phi} \frac{\partial \phi}{\partial N}=b^{\prime}(N) B(\phi)+b(N) B(\phi) \frac{C P^{\prime}(\phi) p^{\prime}(N)-B^{\prime}(\phi) b^{\prime}(N)}{B_{\phi \phi}-C P_{\phi \phi}}
$$

All terms in (10) are strictly positive, and thus the observed connection between cities will overstate the true connection between cities and benefit level. In fact, the observed connection between city size and benefit level will be positive even if $b^{\prime}(N)=0$, as long as $p^{\prime}(N)<0$. Thus a decrease in the probability of arrest may manifest itself as an increase in the level of crimes, and will not show up at all as a change in the observed arrest probability.

This section suggests that endogenizing the level of danger means that while the marginal return of crime must rise with a shift in the arrest rate, the danger margin suggests that individual criminals will lower the riskiness of their behavior in response to this shift. Thus, if cities have lower arrest rates, that may induce more risk taking behavior and higher returns from crime even if the returns to the marginal criminal must climb as the probability of arrest rises. Alternatively, if cities have higher benefit levels we should observe the probability of arrest being higher as well. Conversely an effect where cities lower the probability of arrest will be understated in the data since criminals compensate by taking on more danger. In addition, the fact that higher benefit levels induce more dangerous behavior will cause the observed connection between cities and benefit levels to overstate the true additional returns to criminal behavior. Despite the obvious warning created by this section, we will be forced to use observed benefit and arrest levels, and this section must stand as only as a caution against interpreting them too literally.

The Returns to Crime

A natural hypothesis explaining why cities have a high return from crime is that costs of transport for crime are extremely high, and that criminals perform crimes within a small and specific geographic area. Indeed, 
criminological work strongly suggests that criminals do not travel long distances to perform crimes. The costs of distance are possibly related to the higher probability of arrest facing criminals in the process of leaving the crime or criminals being troubled on route to the crime. The high costs of distance may relate to the possible need to escape the place of crime and return to a safe haven rapidly if the crime goes awry. These costs of distance become particularly high if the criminal is of a socioeconomic or ethnic group that is visibly different from the norm of the victim's neighborhood. Regardless of the source of the costs of traveling to crimes and transporting goods back from crime, the presence of those costs implies that dense urban areas will have higher crime levels. These density levels will show up in larger benefits per crime if the criminals are able to be more selective towards potential victims in dense cities. If density increases the total number of crimes it may reduce the value of each additional crime and still make crime more lucrative. When we look for a connection between urban status and the value of crime, we can hold the number of crimes in the city fixed and just look for a conditional connection between value per crime and cities.

Urban density may play a particular role in street crime, and relatively unplanned petty larceny. If the method of street criminals is essentially to sit and wait for prospective criminals who come within their range of sight, a dense area will have a much larger stream of potential victims then an empty area. In this model, criminals do not go to their victims but rather rely on their victims to come to them. In urban areas where streets are more crowded, more victims will wander within the range of the street criminal. Again, if this force allows criminals to select their victims more carefully this force will lead to higher benefit levels per crime. Alternatively, it may lead to a larger number of crimes per criminal. ${ }^{9}$

Another, source of connection between higher returns from crime and urban areas is the greater informational linkages that are present in cities. Physical proximity, and a high frequency of interactions in urban environments, make it plausible that criminals will be able to learn about a much greater range of victims and thus criminals in big cities will be able to choose the most

\footnotetext{
${ }^{9}$ While we have not made crimes per criminal endogenous, if cities created an exogenous increase in crimes per criminal, this increase would show up in the model as an increase in $B$.
} 
lucrative crime among a greater range of crimes. Greater information flows in cities make it possible for individuals to acquire information that will itself reduce to the costs to the criminal of crime, e.g. learning easier ways to break into apartments. Better information should ensure that criminals choose more lucrative victims.

A particular form of the advantages of density is that cities create crime by creating proximity between wealthy potential victims and poor potential criminals. This proximity will again be valuable both because it limits transport costs and because it eases information flows to the poor about the wealthy. Given the well known facts about the prevalence of poor on poor crime, we are immediately somewhat skeptical about this variant of the density hypothesis, nevertheless it is a valid theory and can be tested since it implies that urban living will be particularly risky for the rich.

A final hypothesis about why cities raise the returns to criminal activity is that urban areas allow scale economies in the resale of stolen objects to function. In cities, markets for either stolen goods or criminal implements (e.g. guns) can exist because the fixed costs of having these markets can be paid by the large market sizes available for these goods. The presence of these markets make it cheaper for criminals to acquire tools and easier for criminals to dispose of stolen property.

\section{Cities and the Probability of Arrest}

Cities might lower the costs of crime by lowering the probability of arrest and the probability of punishment conditional open arrest. A natural hypothesis is that police are much more likely to know the residents of their community in a relatively stable, small town environment. Since the informational connections between police and citizen are weaker in anonymous cities, enforcement becomes more difficult.

One version of this hypothesis is that police solve crimes by considering the full set of possible criminals in a crime and eliminating all but one of the potential criminals. Indeed, basic police procedure textbooks (e.g. Weston and Well, 1993) do recommend just such an investigation process in many 
instances. In small towns, police are able to narrow the range of suspects in any particular crime to a much smaller set and apprehend criminals much more easily. Even if the number of crimes and the number of police grow at the same rate as the size of the city grows, still for any given ratio of crimes to police, apprehension will be harder when the pool of potential suspects is larger, as it must be in urban areas.

Alternatively, the connection between policing and urban areas may come about because cities choose a different bundle of local public goods from small towns. In principal cities may choose to spend a lesser amount and acquire fewer policemen, because urban residents are more tolerant of crime (since they selected to stay in cities), urban residents are more likely to be, know or care about criminals or urban residents are more sensitive towards individual rights. This hypothesis can be tested by examining whether police or police expenditures are lower in urban areas.

A final version of the costs of crime hypothesis is that informal community sanctions are extremely important in eliminating crime. The community may itself monitor and punish criminals or the community may monitor criminals and punish by calling in the outside authorities. Urban anonymity may make it harder for communities to determine who is the culprit and to then inflict punishment.

Also, cities may lower the role of community enforcement, because cities limit the strength of communities themselves. Community enforcement needs to overcome the free rider problems inherent in inducing an individual to take steps to protect his neighbors. Usually these free rider problems are overcome with long term implicit contracts (in the folk theorem manner). If individuals in cities are less likely to be long term residents or individuals believe that urban anonymity protects them if they fail to live up to the community standards in turning in criminals, then these long term implicit contracts will be harder to enforce in cities. This argument is essentially that American cities fail to develop the social capital (see Putnam, 1993) necessary to restrict crime. 


\section{Cities and Exogenous Characteristics}

The previous two subsections have focused on urban features that would act to increase the benefits and reduce the costs of crime. Alternatively, high urban crime levels may simply be the result of individuals with a greater propensity towards crime selecting to live in urban areas. While cities tend to attract on average individuals with more, not less, human capital (Glaeser and Maré, 1995), cities may also attract individuals drawn disproportionately from the bottom of the human capital distribution. These individuals may be attracted to cities because cities may have better job opportunities for individuals with low levels of skills, or because of the presence of urban neighborhoods where they feel comfortable, or because cities offer higher governmental benefit levels, or even because cities offer greater rewards from criminal behavior. For whatever the reason, it is entirely possible that cities have just attracted populations with a particularly high tendency towards crime.

Of course, since a large number of criminals are under the age of 18 and presumably have difficulty choosing their own location, the connection in many cases must be between urban location, parental characteristics, and then through parental characteristics, children's characteristics. Parental characteristics may alter children's characteristics through standard intergeneration transmission of human capital (see Becker and Tomes, 1978) or this integenerational transmission may also work through endogenous development of children's tastes (see Becker and Mulligan, 1994). In this hypothesis, parents with low human capital or tastes related to criminal tendencies come to cities and then because of their characteristics develop criminal tendencies in their children. For this hypothesis to be true, transmission across generational lines must be extremely strong.

Finally, it is possible that cities increase crime primarily because of shocks to urban labor markets that have occurred over the past 40 years. The decline of American manufacturing, and particularly manufacturing in cities, may act to decrease the returns to legal activities and induce a higher proportion of urban residents to go into crime. Similarly, if cities simply lacked good 
employment for the young, then the young would also be drawn particularly into criminal activities.

\section{Cities and Endogenous Characteristics}

The previous subsection argued that cities could be connected to crime because individuals who are crime prone are attracted to cities or that there are characteristics of urban labor markets that happen to be connected to criminal tendencies. Alternatively, it is possible that cities themselves play a causal role in inducing the formation of characteristics that then induce crime. Indeed, Wirth (1938) makes the case strongly that the anonymity of cities and transience of urban residents induces a major alteration in behavior. Above, we interpreted urban anonymity as meaning that police may have more problems identifying criminals, or victims will have more difficulty in reporting crimes. Still Wirth's suggestion that there is a deep connection between urban living and the development of criminal tendencies cannot be rejected out of hand.

For example, if we believe that cities are correlated with poor job opportunities for low human capital individuals, then these low job opportunities might induce different developments of social and individual attributes for young individuals. Perceiving low returns to human capital, or a low return to investments in patience (this argument is a version of Becker and Mulligan, 1994), the inner city youth choose to develop skills and tastes that make crime attractive. It is not the job market itself that induces criminal behavior, and temporary fluctuations in the job market will not have a direct link on the amount of crime, but rather the low returns in the legal sector prompt a series of investment decisions that eventually mean that the benefits of crime exceed the costs. The difference between this argument and the previous section is that in the previous section parents developed children's tastes because of their own attributes. Under this hypothesis, the city location itself plays a strong role in influencing the development of tastes.

A particularly relevant form of this effect can occur if cities are correlated with single parenthood, initially because cities attracted single parents or persons 
with an inclination towards single parenthood. The high levels of single parenthood in large urban areas then may restrict the development of legal sector skills, patience, or ethical restraints on behavior for the children brought up in broken homes. The absence of these forces then induces young persons to then become criminals.

Elsewhere (Glaeser, Sacerdote and Scheinkman, 1996), we have argued that social interactions play a large role in determining the level of criminal behavior. If cities speed the flow of peer influence and make peer influences more ubiquitous then social interactions, and particularly high levels of crime, should be more common in cities (Wilson and Herrnstein, 1984, also make this argument). One implication of this idea is that since social interactions seem to be stronger when families are not intact, then the urban effect of crime will be strongest for the children on non-intact families. ${ }^{10}$

\section{Section III. Victimization Results}

Our first data source is the National Crime Victimization Survey (NCS) administered by the Department of Justice's Bureau of Justice Statistics. The NCS is a survey that asks respondents a battery of background information questions and it asks them whether or not they were the victim of a crime in the prior six months. If the respondent was victimized one or more times, the NCS asks dozens of further questions about each incident.

We will use two different samples from the NCS. In our first sample, we use the full group from the 1989 third quarter interviews. We then limit our sample to the heads of household that were interviewed during that period. The head of household is usually the person interviewed, and we believe that the answers given by the head of household about relevant household information are significantly more accurate than answers given by other members of the household. For the 1989 sample, we have data on both individuals who were victimized and individuals who were not victimized, and therefore this will be the sample for our estimates of the determinants of victimization.

${ }^{10}$ This argument is related to work on neighborhood effects such as Case and Katz (1991). 
Our second sample is from the third quarter interviews of the 1980 incident level file. This sample includes only people who were in fact victimized by a crime during the six months prior to the interview. We use this sample (as well as the 1989 sample) to look at reporting rates and the likelihood that a victim knew the offender. The 1980 data have the advantage of having a much larger sample of victims. Unfortunately, we do not have any information about the non-victims in 1980, so we will use 1980 data only for comparisons between victims not for comparisons between victims and nonvictims.

The NCS surveys are not administered to a random sample of the U.S. population, and so our calculated victimization rates will not be the same as the U.S. victimization rates. However, the non-randomness of the sample should not in any way effect of our estimates of the correlates of victimization.

Our measure of crime is whether or not the respondent was victimized during the period and we will be using two measures of the degree of urban living. Our best measure is the size of the urban place within which the potential victim lived. While the sample does not tell us the exact city, it does give us a range of population values for the potential victim's city. We will also use as our measure of "city" whether or not the person lived in a standardized metropolitan statistical area (SMSA). Our use of SMSA is meant to present a further confirmation of the basic urban crime results and also to create results that will be comparable with the results from the NLSY, where we are forced to use only SMSA as our measure of "city."

\section{Tables $1 A$ and $1 B--$ Means and Standard Deviations}

Means and standard deviations are shown in Tables $1 \mathrm{~A}$ and 1B. We have provided means and standard deviations for all the variables in both samples and we have also provided separate means and standard deviations for SMSA residents and non-SMSA residents. The mean rate of victimization (by any type of crime) in the 1989 sample is 13 crimes per person and $77 \%$ of the respondents lived in SMSAs. The SMSA residents had a mean 
victimization rate of $13.97 \%$; the non-SMSA residents had a mean victimization rate of $8.29 \%$.

For each of the crimes, except rape where we have extremely small sample sizes, SMSA residents had a higher victimization rate than non-SMSA residents. In the cases of larceny and assault, victimization rates were twice as high in urban areas. In the case of house burglary, victimization rates were $20 \%$ higher in SMSAs. In the case of auto theft, victimization rates were three times as high in SMSAs, and in the case of robbery (theft from an individual with the presence or threat of force) victimization was five times higher in SMSAs (again small samples are involved). The raw level of arrests per crime is higher in SMSAs, but this variable is available for only 346 incidents.

The other variables show that SMSA residents are generally younger, better educated, more likely to be African-American and Hispanic, less likely to own their own residence, less likely to be married, more likely to live in an apartment building, and own fewer cars. The urban residents also have much more taken from them on average conditional upon being victimized, despite the fact the personal crimes are a larger share of crimes in cities. People in cities are much less likely to know their offenders than people outside of cities. Table $1 B$ shows similar results for victims in 1980.

\section{Tables $1 C$ and 1D-- Victimization and City Size}

Table 1C presents our first set of results based on the National Crime Victimization Survey. We have eliminated the information that would come from multiple victimizations (there were few), and focused on the probability of having been victimized by some criminal act over the previous twelve months. In general, we have run probit models regressing the probability of having been the victim of a crime on city size and other covariates. The first regression in Table $1 \mathrm{C}$ includes no other covariates and shows the correlation between city population and the probability of being victimized. While the pseudo r-squared is low, the coefficients are extremely significant and imply a large connection between victimization and city size. 
The omitted category in all of the city size regressions is "living in a place with a population of less than 1,000 or an unincorporated place."

The overall results show a strong city size effect. The coefficients on each category of city size rise steadily. The coefficient on city population greater than 1,000,000 implies that people living in those cities have a predicted vicitimization rate of $21.8 \%$. Individuals living in a city with between 50,000 and 99,000 people have a victimization rate of $13.8 \%$ and individuals living in a town with fewer than 1,000 residents or an unincorporated place have a victimization rate of $8.5 \%$. Another way of saying this is that victimization rates are more than $100 \%$ higher in large cities than in tiny towns.

In order to turn these dummies into a simple composite variable that can then be compared with later regressions, we generate the implied elasticity of crime with respect to city size. This implied elasticity came from regressing the logarithm of the predicted victimization rate within each population size on the logarithm of the midpoint of the city population levels in each grouping. The elasticity is thus the percentage increase in the level of victimization generated by a $1 \%$ increase in the population of the city, and the coefficient estimate is .124 . We will want to compare this variable with the elasticities found from the UCR data when we regress the logarithm of crimes per capita on the logarithm of population. While we are generally opposed to taking logarithms of numbers between 0 and 1 that are already a percentage, in this case it is necessary in order to make this figures comparable. The procedure would seem somewhat better if we had used the multiple crimes per victim information.

The second regression in this table includes a number of other covariates. The covariates are basically chosen because other data sets have comparable variables. Our results are in line with the general victimization results (see e.g. Radzinowicz and Wolfgang, 1977). Older people are less likely to be victimized. Men are more likely to be victimized. We find that individuals with more schooling are more likely to be victimized (which we found somewhat surprising). There was no race or ethnicity effect and little employment effect. Homeownership was substantially linked to avoiding victimization. Marriage was substantially linked to lower victimization rates. 
It is important to be careful in interpreting these results. First, it is very difficult to know from this regression whether or not a result changes sign if other covariates are removed. Since these are partial correlations, the total correlation between one variable and victimization may be positive, but because of we are holding other covariates constant the observed correlation becomes negative. Second, the mechanism that drives any of these correlations is difficult to deduce from this table. For example, a first stage criminal framework might suggest that optimizing criminals might victimize the wealthy before they victimize the poor. On the other hand, a second stage framework would suggest that the wealthy would undertake more selfprotection and if self-protection was easier for them than for the poor (perhaps because of where they lived), then we might very well see a negative effect of income of victimization (see Becker and Ehrlich, 1972). However, we will not know if that effect is because criminals do not target the wealthy or if the wealthy are good at self-protection or any number of other hypotheses.

The effect of including these covariates on the city size dummies is indeed significant. The coefficient on city above one million drops from .588 to .361 . The implied elasticity falls from .124 to .079 , a drop of approximately onethird. It does seem that a significant portion of the urban crime effect comes through characteristics of victims. Cities have more individuals who are either easier or more lucrative victims and this effect seems to explain approximately one third of the city crime effect.

Two possible explanations for the homeownership effect are that this effect is in fact capturing property ownership and stability and that this effect is in fact proxying for the type of housing that one chooses to inhabit, i.e. apartment vs. detached home. Since the housing stock is an integral part of an urban area, we checked for this possibility by including a dummy for whether the victim lives in an apartment building. While that dummy is statistically significant and apartment dwellers are more vulnerable to crime, the coefficient on homeownership changed only slightly so we must conclude that homeownership has an independent effect other than apartment vs. home dwelling (or that our variable for apartment dwelling is simple too coarse a measure). Including the apartment dwelling variable did not change the 
connection between crime and urban size significantly. We interpret the significant coefficient on apartment dwelling as further evidence on the important connection between density and crime.

Regressions (4)-(6) in this table repeat regressions (1)-(3) but use a dummy for whether or not the potential victim lived in a metropolitan statistical area (SMSA) as the measure of city. Regression (4) shows an SMSA coefficient of .303, which shows that SMSA dwellers have significantly more victimizations than non-SMSA dwellers. Regressions (5) and (6) show that this coefficient drops again by $1 / 3$ when we control for the other covariates. In general, the coefficients on the covariates are very similar between regression (2), (3), (5) and (6). The one exception (and that exception is not even statistically significant) is the apartment dummy which climes from .139 to .175 as we move from regression (3) to regression (6). The natural interpretation of this result is that in regression (6) the apartment dummy is correlated with city size and its importance is being overstated because of its correlation with city size. While, that fact is not intrinsically important, it is interesting to note the strong connection between crime, housing choice and level of city size.

Table 1D continues this analysis using the SMSA dummy and interacting that dummy with dummies for high and low income status. While the cross effects are not statistically significant, they are large in economic magnitude. In particular, the results seem to suggest that the SMSA effect is strong on both low and middle income individuals, but much weaker for high income persons. By combining the cross effect and the SMSA dummy, it is possible to see that the coefficient for high income persons is .115 (which is not statistically significant) and the coefficient for middle income persons is .21 . While these results are not that strong statistically, it seems that the victimization effect of living in a big city is much higher for the poor than it is for the rich perhaps because of the opportunities of the rich for self protection. ${ }^{11}$ A natural implication of this result is that the urban crime effect is not because poor people are able to rob rich people in cities, but rather that density makes it easier to rob from one's neighbors.

${ }^{11}$ This result is robust to controlling for whether the rich person lives in a suburb. 
In order to further understand these effects regressions (2) through (5) look at personal crimes (primarily theft from a person, but also rape and assault) and burglary separately. The SMSA effect is stronger for personal crime than it is for house crime, but the results do not look all that different from each other or from the results from all crimes together. While most of the coefficients are fairly similar between the house crime and the personal crime regressions, we find that African-Americans are much less likely to be victimized by burglary and much more likely to be victimized by personal crimes. We also find that the apartment effect is working through personal crime, not burglary. Hence, the danger associated with apartment living seems not to be in lower security of one's apartment but instead from contact with near neighbors or the overall density of the area. The basic income cross effect seems somewhat stronger for personal crime rather than for house crime, where the SMSA effect on rich people is weaker than the SMSA effect on poor people.

To examine crimes that are completely free from the financial returns to crime, we examined assault victimizations. These crimes have been defined so that these are only assaults that are violent crimes against an individual and are not in any way associated with attempted or realized theft. Our goal was to focus on violent crime unrelated to financial rewards. We find that the SMSA effect rises for this variable considerably, which suggests that at least in terms of this variable high financial returns from crime cannot be explaining the SMSA effect.

\section{Table 1E-- Victimization and the Returns to Crime}

To examine the financial returns from crime more closely, Table 1E shows the effect of SMSA status on the average value of goods taken in a property crime. This regression shows a strong income effect, and also that minorities have more stolen from them on average. Because of the small sample size, we have included a smaller set of covariates. The SMSA effect on value is significant economically (representing a more than $20 \%$ high level of average value in SMSAs) but not statistically. To examine this issue further, regression (2) used 1980 data where we have many more victimizations. In 
the 1980 data, the SMSA coefficient on value is lower but statistically more significant.

In regression (3), we use city size dummies rather than the SMSA dummy. We find a sizable city population effect, but much of that is driven off higher returns within the very largest cities. This effect is not the result of a few outliers in larger cities; we have truncated the losses in values taken at $\$ 10,000$. Surprisingly, though, the value taken results are much weaker for all smaller population categories, so while value taken might explain higher crime rates for the highest population grouping, it would be difficult to state that these data suggest a possibility that higher returns from crime explain the higher crime rates for medium size cities.

Regression (4) includes a larger battery of covariates and also looks at cross effects between SMSA and income categories. Higher values for urban crimes is a fact primarily for middle and low income individuals. Again the rich seem relatively immune to the SMSA effect. These cross effects seem to match the cross effects for the victimization rate regressions in an interesting that we believe is relevant. The groups that suffer most from crime in terms of numbers of crimes in urban areas also lose the most on average in those crimes. Given that higher quantities of crime should reduce the average benefit per crime, we think that cities do seem to increase the efficacy of crime quite highly. However, some of these results might by reflecting criminals in cities choosing more dangerous crimes.

Regressions (5) and (6) divide the value evidence into house crimes and personal crimes. The effect of SMSA on the value taken from the house is much larger than the effect of SMSA on personal crime. Surprisingly this finding runs contrary to the evidence in the prior table where SMSA's had proportionately more personal crime. The average crime is of higher return in cities and in particular the income groups that lose more on average in cities are also more likely to be victimized. However, most of the urban effect on value taken occurs only for very large cities and occurs for burglary, a relatively less urban crime. 
Table $1 \mathrm{~F}$ relates city size to the potential costs of committing crime. In particular, we are testing the hypothesis that in urban areas crimes are reported less so it is less likely that police will be involved and arrest will occur. Ideally, we would like to be able to use arrest data themselves but we do not have them in this data set. Overall, we find a connection between reporting and city size in both the 1989 and the 1980 data sets, but it is a weak connection at best. The 1989 data set suggests that middle size cities have the strongest reporting rates but that victims in big cities and small cities both are less likely to report. The larger, and presumably more accurate, 1980 data shows even less of a connection between city size and the probability of reporting. Regression (3) shows that the SMSA dummy on reporting is insignificant. The reporting results are weak and while we will try correcting later results for reporting error we do not find a strong pervasive connection between reporting tendencies and city size.

Much more persuasive are the results in regression (4) and (5) which regress the probability that one knows one's offender on the city size dummies and the SMSA dummy. In both regressions, we find a strong negative connection between urban living and knowing your offender. The probability of being known is $40 \%$ lower in big cities than it is in small towns. This variable is only available for 932 observations in the 1980 data and surely plays little role in crimes where the victim has little chance of seeing the offending person, but it is entirely possible that this anonymity plays a role in raising crime levels in big cities. ${ }^{12}$ The concluding section will use estimates of other parameters to place a bound on the magnitude of this effect.

\section{The NLSY Data}

Our second data source is the National Longitudinal Survey of Youth, which has been used elsewhere for information about crime and individual attributes (Freeman, 1992, or Grogger, 1995, for example). The sample is drawn in the following manner: the 1980 questionnaire asked respondents a

\footnotetext{
${ }^{12}$ This result is robust to including dummy variables for the type of crime that was committed.
} 
group of questions regarding whether or not they had engaged in various criminal activities. Our sample takes all respondents who a.) answered these questions and b). for whom we know basic family and individual characteristics (e.g. race, income, census region) around the year 1980. This data set is essentially a data set of potential criminals and it relies on selfreported admissions of criminality.

While we are skeptical about relying on self-reported criminality measures, the high degree to which individuals seem to freely admit to petty crimes makes us somewhat more reassured. In fact, a neutral tendency to underadmit to crime will not lead to biased results, simply large error terms. More troubling is a tendency to underadmit that is correlated with urban status. In the event that there is a underreporting bias, our results must understood as containing both results about the true level of crime and individuals willingness to confess to crimes. ${ }^{13}$ The alternative was to use an outcome variable such as actually being interviewed in prison. We avoided using this variable both because it has been explored elsewhere (e.g. Grogger, 1995) and because it combines information on both committing crimes and being arrested. Finally, using prison location as an outcome immediately confounds regressions that try to use the physical location of criminals as an explanatory variable.

Neither the NLSY nor our sample are meant to be a random sample from the population of U.S. youths. In particular, the NLSY over-samples minorities and people from inner city areas. There do exist weighting measures to correct for this problem, and using these measures does not make a difference in final results, so we have reported unweighted measures.

While one might expect that a random sample of individuals would yield few criminals, the over-sampling of the poor and the fact that this sample is made up of young individuals (mean age of 20), helped ensure that we have fairly high rates of criminal behavior. Nevertheless, we do not have a large

\footnotetext{
${ }^{13}$ The connection of crime with age ands sex that we find in the NLSY corresponds with what is generally known elsewhere about criminal behavior. The race effects do not correspond to other measures of criminal behavior, and perhaps should be seen as the result of different reporting patterns across race, which other researchers have also found.
} 
enough sample size to examine any but the pettiest of crimes. Also, the underreporting problem should be less severe when the respondent is less concerned about the severity of the crime. We use several crime measures. For our primary measures of crime we create 0-1 variables for a.) whether or not a person stole something with value less than $\$ 50$ in the past year, and b.) whether or not the person shoplifted in past year. We use one basic city measure, which is whether or not the respondent lives in an SMSA according to the standard Census Bureau designations of SMSAs.

A further problem with these data is the fact that we are forced to rely on an SMSA dummy. While there also exists a set of identifiers for central city residence, much of the sample did not know whether or not they lived in a central city. As a result the central city dummy (which is a combination of living in a central city and understanding that you live in a central city) may be correlated with high human capital in a way that is unacceptable for our results. Moreover, the levels of crime across the central city/non-central city showed no central city effect which is not compatible with other data sets, and a wide range of evidence that suggests that central city location is intimately related to crime levels. We interpreted our lack of evidence as suggesting that there was a problem with using this extremely noisy measure of central city location.

\section{Table 2A-- Means and Standard Deviations}

Data means and standard deviations by SMSA and non-SMSA are shown in Table 2A. $69 \%$ of the sample lived in an SMSA. This figure is comparable with figures from the statistical abstract or from the victimization survey. Roughly $18 \%$ of the sample reports having stolen something worth less than $\$ 50$ in the last year and $27 \%$ reports having shoplifted. The rate of theft for SMSA residents is $19.66 \%$ and the rate of stealing for non-SMSA residents is $15.88 \%$. There are $28.6 \%$ of SMSA residents who shoplifted and $22.11 \%$ of non-SMSA residents who admitted to shoplifting. In other observables, there are few differences between the two samples. SMSA residents are much likelier to be Hispanic and to have used marijuana. SMSA residents are also much likelier to have been stopped by police, but the conviction rates are roughly equal in the two samples. 
Tables $2 B$ and 2C-- Criminality, SMSA Status and Background Characteristics

Tables $2 \mathrm{~B}$ and $2 \mathrm{C}$ presents our results on the determinants of criminality, as opposed to the determinants of victimization. The first regression in this table shows the raw connection of SMSA location with the probability of having stolen property worth less than $\$ 50$. The raw coefficient is .1085 . Table $2 \mathrm{C}$ regression (1) repeats the same regression with shoplifting as the dependent variable. In that regression the coefficient is .1576 . While these differences are extremely big statistically, they are smaller than the numbers in the victimization records. Furthermore, SMSA residence explains only about $1 \%$ of the individual variation in the levels of crime.

Regressions (2) and (3) in Tables $2 \mathrm{~B}$ and $2 \mathrm{C}$ show the effect of controlling for demographics and parental background variables on the propensity to commit crime. Regression (2) in both tables includes age, age squared, the local unemployment rate, a dummy for family intact when the individual was 14, the highest grade the individual achieved, a male dummy, and racial demographics. The age, sex and race variables are all strongly significant and have the signs found in almost all previous work of this nature (see Wilson and Herrnstein, 1984). The family intact variable is powerful and, as expected, children of intact families are less likely to commit crimes. The schooling variable is significant (and in a surprising direction) for property theft and insignificant for shoplifting. Controlling for these demographics increases the SMSA effect in both Table $2 B$ and Table $2 \mathrm{C}$, but in neither regression is the change significant economically or statistically. This change is also partially related to the weighting scheme-- weighting makes a difference only when there are not these primary covariates in the regression, so that the raw regression is somewhat less accurate than the regression with other controls.

Regression (3) includes the SMSA status at age 14, having migrated, highest grade achieved by the individual's mother, whether or not the mother worked when the individual was 14, the individual's AFQT score and whether or not the individual attends church once a month or more. In the shoplifting regression SMSA status at age 14 is significantly positive and approximately $50 \%$ of current SMSA. In the property theft regression, lagged 
SMSA status has approximately $1 / 3$ of the current SMSA effect. An interpretation of this finding is that lagged SMSA status suggests that at least $1 / 3$ to $1 / 2$ of the SMSA crime effect is not the result of the higher costs and lower benefits of crime in the urban area. Instead the lagged SMSA effect probably relates to either omitted variables that are correlated with SMSA status (at one point in time) or tastes and outcome variables that are the result of SMSA status that do not change when the individual leaves the SMSA. The migration dummy is just meant to ensure that the lagged SMSA effect is not simply the result of migrants have a different propensity towards crime.

The other variables generally came in significantly. Mother's schooling has the opposite sign than expected-- more schooling increases the propensity towards crime. In the shoplifting regression, the mother working increases the propensity towards crime. Churchgoing significantly reduces the propensity towards crime and the AFQT scores are also strongly negatively connected with the propensity towards crime. Again, no one of these variables should be given too strong of an interpretation because we are observing only the partial effect of more maternal schooling, holding AFQT scores, family intact, schooling, location, and other variables constant.

In regression (3) of both Tables, the SMSA variable rises. The coefficient on SMSA has risen $21 \%$ between regression (1) and regression (3) in Table 2C. The coefficient on SMSA has risen $71 \%$ between regression (1) and regression (3) in the shoplifting regression. The final coefficients in these probits are very close to the coefficients on SMSA in the victimization probits reported above. At least in the NLSY data, controlling for a battery of individual and familial characteristics increases the connection between city living and criminal propensities. We cannot say whether this effect would withstand including a wider battery of individual characteristics, but at least in the variables the we have (and with other variables in the NLSY that are not reported) we did not substantially lower the SMSA effect by controlling for more attributes.

Regression (4) in both tables includes a variable for the number of times that the individual used marijuana in the past year. In both cases, the effect of marijuana usage was deeply positive and significantly reduced the SMSA 
effect. We are highly uncomfortable interpreting this effect as a demographic control or as something completely related to the effects of drug use. Instead, we interpret this regression as implying that the same urban features that lead to more drug use also lead to more criminal theft and that these urban features account for perhaps $50 \%$ of the SMSA crime effect. Within that $50 \%$ share is both anything that cities do to increase drug use (greater availability, lower stigma, etc.) and the effect of drug use on crime and anything that would effect the propensity to do drugs (i.e. lower stigma, weaker community monitoring) that also directly affects criminal propensities.

The final regressions test whether the SMSA effect is different for different groups. In the shoplifting regression, higher AFQT individuals have a much lower SMSA effect, but differences in race or family composition do not change the SMSA effect. While these results technically reject the joint hypothesis that cities work through social influences and these social influences are more important for children with weak families, the standard errors on our estimates are so large that this data can only tell us that we are not sure yet about this hypothesis. The interaction between AFQT and SMSA is significant in that regression and suggests that the effects of cities are much less deleterious for individuals with high levels of skills. In the property theft regression, the SMSA effect was lower for blacks and lower for individuals with family intact, but in neither case was the effect significant.

Table 2D-- The Costs and Benefits of Crime

In order to further investigate how city status interrelates with the costs and benefits of crimes, regressions (1) and (2) in Table $2 G$ regress whether or not an individual received a "significant" amount of income in the past year from criminal activity. Regression (1) shows the coefficient of SMSA on having significant criminal income for all individuals in the sample. Regression (2) shows the results only for individuals who have admitted to either shoplifting or stealing property.

In regression (1) SMSA has the expected sign, so urban residents are more likely to receive significant income from criminal activities. However, in regression (2) we see that this SMSA effect is working completely through the 
propensity to be a criminal and conditioning on criminal behavior there is no connection between the financial rewards of crime and urban status in this data. While this regression is certainly not convincing on this topic, it does provide a source of information on the importance of higher criminal rewards inducing more crime in cities. Alternatively, one can interpret this as a result that cities induce more casual criminals but do not influence the margin between casual and professional criminals.

Regressions (3)-(6) use the NLSY to address the issue of higher probability of apprehension and punishment in urban areas. In regression (3), we see that urban individuals are indeed more likely to be stopped by a policeman. In regression, (4) we see the urban individuals are also more likely to be stopped by a policeman conditional upon their having committed a crime. One comforting fact in regression (4) is that only current SMSA status is important-- past SMSA status does not reveal anything about the probability of being stopped conditional upon committing a crime. This implies that the SMSA variable may actually have to do with conditions in the SMSA and not individual characteristics that are correlated with SMSA status. Regression (4) suggests that the costs of crime are higher in SMSAs not lower.

In regressions (5) and (6), we regress the probability of ever being charged with a crime and the probability of ever being convicted on our variables. In both regressions, we include only admitted criminals. There is a positive, insignificant effect of SMSA status on being charged with a crime and a negative insignificant effect of SMSA status on being convicted. We find these results unconvincing on whether cities are either more or less dangerous places to commit crimes. As a result, we are hesitant about thinking that higher probabilities of arrest outside cities drive the SMSA crime effect.

\section{Table 2E and 2F-- Patience, Violence and Crime}

We have so far focused on fairly standard individual behavior, where we are including as control variables standard demographic controls. In this section, we include endogenous behavioral variables that are meant to capture the degree to which particular tastes are driving criminal behavior. Then we ask 
if these tastes are either correlated with urban status, or in fact the result of urban location. This experiment is similar to the including of marijuana consumption as an explanatory variable. Finding that the urban crime effect changes as we include these other behavioral decisions does not eliminate the urban crime puzzle, but it does tell us that we should look for theories of the urban crime premium where city status effects both criminal behavior and these other individual actions.

Tables $2 \mathrm{E}$ and $2 \mathrm{~F}$ are identical except for the fact that $2 \mathrm{E}$ uses property theft and $2 \mathrm{~F}$ uses shoplifting as dependent variables. Our first two behavioral variables are individual choices that we believe are determined in part by an individual's level of patience, or his or her ability to delay gratification. While, these variables are quite possibly related to other factors as well, we believe that this approach is one way of asking empirically whether (as in Banfield, 1974) impatience drives crime. In regression (1) we include the age that the individual first had sexual intercourse as an explanatory variable. In both regressions, this variable is extremely significant in predicting criminal behavior. In both regressions, including this variable lowers the SMSA coefficient. In regression (2) we include whether or not the individual has a savings account. This variable is less successful but also seems to be negatively correlated with criminal behavior.

In regression (3) we proceed from patience to the taste for violence and we try to measure this taste with a question that asks whether the individual fought at school or work in the past year. In both regressions, the variable is quite significant and again lowers, although only mildly, the urban crime coefficient. When we include all three variables, the age of intercourse and the fight variable both are strongly significant, the savings account variable is essentially irrelevant. The SMSA coefficient is $19 \%$ lower when we include these variables in the shoplifting regressions; the effect of these variables in the property theft regressions is to lower the SMSA coefficient by less than $3 \%$. So while these variables do seem to be quite important, the SMSA effect is not determined by these variables.

In regression (5) of both tables, we include additional variables relating to patience and the propensity towards violence. These new variables include 
whether an individual had sex without birth control in the previous year (insignificant in this regression), the age an individual started drinking which is significant in both regressions (although perhaps because alcohol itself effects crime and not through any connection to patience), the age an individual started smoking cigarettes (which is highly significant) and whether are not the individual attacked someone with the intent to injure or kill in the previous year (which is significant). Overall these variables seem to be quite important and suggest that crime is tied to a variety of other decision in all of which patience plays a major role. However, these variables do not explain the urban crime effect.

Table 2G-- The Determinants of Patience and Violence

In Table 2G, we regress the measures of patience on SMSA status and on other individual background variables. In regression (1), we find that SMSA status is essentially uncorrelated with having a savings account. Other demographics do however seem to be quite correlated with this decision. In regression (2) we find that both SMSA status now and SMSA status at age 14 are quite correlated with the age at which the individual first had sexual intercourse. It seems that urban status is quite connected to the probability of early sexual activity. Family intact variables are strongly correlated with both of these patience variables as is religious activity and AFQT score.

Urban status is also significantly related to the propensity to have had sex without birth control in the previous year. Urban status is uncorrelated with the age an individual stated drinking and uncorrelated with an individual's tendency to fight. Overall, we think that these variables are intrinsically interesting as they are intimately related to taste variables like patience and the taste for violence and they do suggest the influence of locational, social and parental variables on these tastes variables, but we do not believe that they play a large role in explaining the urban crime effect.

\section{The Uniform Crime Reports Data}

Our final data source is the FBI's Uniform Crime Reporting (UCR) Program. These data give us crimes, arrests, and value of property taken by city by year. 
We link the UCR data with city demographics from the County and City Databook (CCDB), and these demographics have generally been drawn ultimately from the U.S. census. Our sample includes those cities with more than 25,000 people and for which we have both CCDB and UCR data .

The UCR data are based upon law enforcement agencies' reports to the FBI regarding the number and type of crimes reported in the local jurisdiction. A well known issue is the potential for UCR numbers to understate the extent of criminal activity if citizens under-report to police crimes that occur. Of course, the seriousness of the reporting problem varies with the type of crime. While, the Uniform Crime Reports have been much maligned, they are still the best data source available for examining cross-city variation in the number and nature of crimes.

We will employ a simple solution to the reporting problem. For our results we are primarily interested in underreporting, so far as it is related to city size, so we will be concerned with correcting for differential levels of underreporting in differently sized cities. The National Crime Victimization Survey enables us to estimate the ratio of (reported crimes / actual crimes) by city size. We use this ratio to adjust upwards by city size the UCR crime rates. Since larger cities appear to have more under-reporting, larger cities get a larger adjustment.

\section{Table 3A-- Means and Standard Deviations}

For the UCR data, our measure of crime is the number of serious crimes (murders, rapes, robberies, assaults, larcenies, burglaries, auto thefts) divided by the population. This is the standard FBI measure of the crime rate. Means for the data are shown in Table 3A. Table 3A shows that there are about 7 crimes per year for every hundred people and that there are about .24 arrests made for every crime. (These are the raw data and not adjusted for underreporting.) Figures 1 and 2 show the connection between the logarithm of serious crimes per capita and murders per capita and the logarithm of city population.

Table 3B-- Crimes per Capita from UCR Data 
In Tables 3B through 3D, we examine the results from uniform crime reports data for 1985 . The unit of observation is the city and our measure is the logarithm of crime rates per capita. In regression (1) of Table 3B, we find that the coefficient on the logarithm of city population is .1635. This corresponds to the implied elasticity found in Table 1B of .22. Regression (2) includes a variety of standard demographics, and shows that the coefficient drops to .1016. The bulk of this drop (90\%) can be created by including only pure demographics. Including the percent female head of household in regression (3) induces a further drop to a coefficient of .0933. The only significant controls in regression (3) are the percent non-white which has a negative effect on the crime rate (this negative sign switches if percent female headed household is excluded from the regression as shown in regression (2)) and the percent female headed household, which has an extremely positive effect on the crime rate. The inclusion of these demographics reduces the urban crime coefficient by $43 \%$.

This decline corresponds to the similar decline in the elasticity of urban crime rates with respect to population size shown in the victimization data when we included similar demographics. Including demographics in the NLSY data did not have a similar effect. There are two interpretations. One is that in cities the characteristics of victims explain the higher crime rates, not the characteristics of criminals. The second interpretation is that our NLSY data are significantly less accurate, and less appropriate since we are only using the SMSA dummy, than the UCR or victimization data. ${ }^{14}$

Regression (4) adjusts the crime rate data for underreporting. In this regression, we have multiplied the crime rates by one divided by the percent of crimes reported to find an estimated number of total crimes. This adjustment was done using a different reporting probability for each population class of cities. Making this adjustment significantly increases the coefficient; although it does not change the percentage of the urban crime effect that can be explained by city level demographics. Regression (7) shows

\footnotetext{
${ }^{14}$ Of course, when we ran victimization regressions using the SMSA dummy demographics reduced the coefficient on that dummy by approximately $33 \%$ as well.
} 
the adjusted crime rate results without any covariates. Including the covariates creates a $30 \%$ drop in the coefficient on city size in this case.

In regressions (5) and (6), we reproduce the victimization results on non-theft related crimes. We used assaults per capita in regression (5) and found the coefficient on assaults per capita was extremely close to the coefficient for serious crimes as a whole. In regression (6), we used rapes per capita and found that the city size effect on rapes per capita was much higher than the city size effect on serious crimes generally. These results do again ensure us that at least for this subset of crimes, the urban effect is not working through higher financial rewards of crime.

Table 3C-- The Costs and Benefits of Crime from UCR Data

In Table 3C, we look at the financial rewards and the probability of arrest as a function of city size. Table $3 C$ regression (1) connects value per crime with city size (controlling for crimes per capita) and finds that urban areas have more valuable crimes than non-urban areas. The coefficient is quite significant and the elasticity is larger in magnitude than the elasticity that connects crime itself with city size. This coefficient is, however, comparable to the elasticity found from victimization data. Thus, it does seem possible that a significant portion of the urban crime effect may derive from higher value of crime.

In Table $3 C$ regression (2), we regress arrest per crime on city status and find no connection between urban population and arrests per crime (this result does not change if we condition on serious crimes per capita which is essentially orthogonal to arrests per crime). In regression (3) we adjust arrests per crime, again using the report information from the victimization data, for the fact that not all crimes are reported and fewer crimes are reported in large urban areas. Once we perform this adjustment the connection between arrests per crime and city population becomes strongly negative so that it does seem that arrests per reported crime are lower in cities. Of course, all of this effect is coming through lower reporting rates in big cities. In regression (5) of this table we regress the natural logarithm of police officers per capita on city 
size and find that it is sharply rising in city population, so the lower arrest rates cannot be caused by lower numbers of police in urban areas.

Regression (6) of this table includes value per crime and arrests per crime in the basic crime regression and finds that including these variables does not lower the coefficient on city size at all, despite the seeming connection between higher value per crime and urban status. One explanation of this finding is that we are not properly measuring the effect of higher benefits and lower costs on criminal behavior. As both of these variables are endogenous to the number of crimes, the negative correlation between value per crime and serious crimes per capita cannot be interpreted as suggesting that more valuable crimes induce less crime but rather that more crimes makes the average value of crime per capita lower (as discussed in the theory section above).

Figures 3, 4 and 5 show results on crimes per capita, arrests per crime and value per crime for the sample as a whole. Figure 3 shows the results by population decile in the Uniform Crime Reports. Figure 4 shows the results, and includes the corrections for underreporting. Figure 5 normalizes the results in Figure 4 so that it is easier to see that underreporting increases connection between city size and arrests per crime.

Table 3D-- How much of the effect of city size is coming from rewards and benefits?

To deal with this problem we need instruments that would allow us to estimate the elasticity of criminal behavior with respect to the costs and benefits of crime. While such an exercise is beyond the scope of this paper, luckily such figures do exist elsewhere. Levitt (1995) estimates the elasticity of the number of crimes capita with respect to the arrest rate at .2 .15 Under assumptions given above it is possible to believe that a similar elasticity should also apply to the value of crimes as well. As such it seems reasonable to begin our analysis by assuming that the coefficients on $\log$ of value per crime and on the log of arrests per crime are .2 and -.2 respectively. We are

${ }^{15}$ Other estimates of this elasticity could conceivably be generated by the older literature on deterrence such as Ehrlich (1975). 
using Levitt's estimate of the elasticity of crime with respect to arrest probability and assuming that $\mathrm{B} / \mathrm{PC}$ equals one. This second assumption is equivalent to assuming that the non-apprehension related costs of crime are small and the community stigma effects of crime are small. In regression (1) of Table 3D, we find that including costs and benefits of crime reduce the coefficient on city size by an additional $33 \%$ relative to the parameter estimate given in Table 3B.

In regression (3) of Table 3D, we increase the elasticity estimates to .3 and -.2 . We are here again assuming that the elasticity of crimes with respect to arrests is .2 , but here we are also assuming that $\mathrm{B} / \mathrm{PC}$ is equal to 1.5. This assumption is equivalent to assuming that the social stigma costs and the nonapprehension costs of crime are together $50 \%$ of the apprehension costs of crime. All of these assumptions should be seen primarily as a form of sensitivity analysis, rather than a strong commitment on our part to a particular value for one of these estimates. These corrections substantially reduce the connection between cities and crime rates, and this correction is working primarily through the value of crime and not the arrest rate. The connection between arrest rates and city size (from Table $3 C$, regression (2)) is much weaker than the connection between value per crime and city size (from Table 3C, regression (1)), so that controlling for arrest rates makes much less of a difference than controlling for city size. Of course, if the primary effect of lower arrest rates is to induce criminals to take on more risk, then the higher value per crime will itself be a reflection of the arrest rate.

In regression, (3) we keep the value of $\mathrm{B} / \mathrm{PC}$ fixed at 1.5 and increase the estimated elasticity of crime with respect to arrests to -.4. This increase drives the coefficient on city sizes away almost completely.

Regression (4) and (5) present results using the crime rates adjusted for underreporting and find similar results. Using coefficients of .2 and -.2 the coefficient on city size falls by approximately $25 \%$-- using coefficients of .3 and -.2 the coefficients on city size fall by $30 \%$. In these regressions the elasticity of the arrest rate is more important since the adjusted arrest rate is much more strongly correlated with city size than the unadjusted arrest rate. 


\section{Table 4-- A Final Decomposition}

In Table 4, we present the final results on the decomposition of the connection between city size and crime. The first panel presents the basic equation ( $\left.3^{\prime}\right)$ and the raw elasticity that is to be decomposed. The next panel shows the amount of the effect that is related to observable variables. Approximately, one-third of the urban crime effect can be explained with simple exogenous demographics. However, when we include both exogenous and endogenous variables, we find that all variables other than female headed household are irrelevant or small in magnitude and that female headed household is the primary factor in reducing the city crime effect. These decompositions were done in the manner of Murphy, Shleifer and Vishny, where we decompose the city effect into a direct effect and an indirect effect through other variables. The total indirect effect is found by multiplying the coefficient on the other variable times the coefficient found by regressing that variable on city size.

The third panel in the table shows the results on the benefits of crime given a variety of assumptions about the ratio $\mathrm{B} / \mathrm{PC}$ and the elasticity of crime with respect to arrest. Using a point estimate of .2 for the elasticity of the probability of arrest, and an estimate of 1.5 for the ratio of $B$ to PC, we find that the benefits effect is .044 , or $27 \%$ of the urban crime effect.

The fourth panel shows the results on the arrest rates. The first values give the magnitudes involved if the arrest rates used are arrests per reported crimes. The second values used take the arrest rates to be arrests per actual crime. In fact, the issue of which arrest measure to use depends on whether .2 is interpreted as the elasticity with respect to arrests per reported crime or arrest per actual crime. Levitt's estimation tends towards the prior interpretation, but since our work is in the manner of a sensitivity analysis rather than a wholehearted acceptance of any one estimate, we present both possibilities. If we use arrests per reported crime, the arrest effect is at most a small contributed to the total urban crime effect (less than 3\%). Alternatively, using arrests per actual crime means that arrest explain close to $13 \%$ of the urban crime effect. 
Finally, the fourth panel looks at the effect of knowing ones attacker. This estimate hinges on the value of KS/PC. While we have little way to get even a reasonable estimate of the magnitude of informal versus formal sanctions, we have used .25 as our point estimate. Using this value, still only implies that being known by one's victim only reduces the urban crime effect by less than $5 \%$. The final total shows how the base elasticity can be decomposed into its various components.

\section{Conclusion}

This paper has attempted to explain the connection between city size and crime rates. Forty-five percent of this connection can be explained by the fact that families are much less intact in cities. Twenty-six percent of the connection can be explained by higher benefit levels in cities and twelve percent can be explained by lower probability of arrest. The relatively small residual is a combination of probability of recognition, and presumably other non-available variables.

While much of the level of female headed households can be explained by simple demographics (over $80 \%$ ), this paper still leaves unanswered the question of why this variable is so important in leading to criminal behavior. We have presented a variety of connected results showing that variables relating to patience or violence are connected with crime and that these variables are connected to family structure, and we believe that later work should continue in this vein and attempt to understand these connections more clearly.

The results on higher benefit levels and lower arrest rates are intriguing but also not entirely satisfying. Since levels of danger are endogenous, we are unclear as to how much the observed connections between city size and these variables reflect different choices that criminals make. Furthermore, if there is a strong connection between city size and benefit levels, we are not quite sure how that connection comes about. The only hypothesis that we feel comfortable in rejecting is the idea that cities raise benefit levels by increasing the access of poor criminals to wealthy victims. Understanding why urban residents have lower arrest rates is also a remaining puzzle. Although we do 
know that urban residents are much less likely to report the crimes and that this is the bulk of the arrest effect.

\section{References}

Archer, D. and R. Gartner (1984) Violence and Crime in Cross-National Perspective. New Haven: Yale University Press.

Becker, G. S. (1968) "Crime and Punishment: An Economic Approach," Journal of Political Economy 76: 169-217.

Becker, G. S. and I. Ehrlich (1972) "Market insurance, self-insurance and selfprotection," Journal of Political Economy 80.

Becker, G. S. and C. Mulligan (1994) "On the endogenous formation of time preference," mimeographed.

Becker, G. S. and N. Tomes (1978) "An equilibrium theory of the distribution of income and intergenerational mobility," Journal of Political Economy 87: 1153-1189.

Blumstein, A. and J. Cohen (1979) "Estimation of Individual Crime Rates from Arrest Records," Journal of Criminal Law and Sociology 70: 561-585.

Case, A. and L. Katz (1991) "The Company You Keep: The Effects of Family and Neighborhood on Disadvantaged Youths," NBER working paper.

Chaikin, J. (1978) "Rand Prison Inmate Survey," Rand Working Paper WN10107-DOJ.

Ehrlich, I. (1975) "The Deterrent Effect of Capital Punishment: A Question of Life and Death." American Economic Review 65: 397-417.

Flango, V. and E. Sherbonou (1976) "Poverty, Urbanization and Crime," Criminology : 331-346.

Freeman, R. (1992) "Crime and the Employment of Disadvantaged Youths," in A. Harrell and G. Peterson Eds. Drugs, Crime and Social Isolation: Barriers to Urban Opportunity. Washington, D. C. : Urban Institute Press.

Glaeser, E. L., B. Sacerdote and J. Scheinkman (1995) "Crime and Social Interactions," Quarterly Journal of Economics, forthcoming.

Grogger, J. (1995) "The Effect of Arrests on the Employment and Earnings of Young Men," Quarterly Journal of Economics CX (1): 51-72.

Harries, K. (1976) "Cities and Crime: A Geographical Model," Criminology: 369-386.

Jacobs, J. (1961) The Death and Life of Great American Cities. New York: Random House.

Jarrell, S. and R. House, (1990) "Transient Crowding and Crime: The More Strangers in an Area the More Crime except for Murder, Assault and Rape," American Journal of Economics and Sociology 49(4): 483-494.

Lane, R. (1979) Violent Death in the City: Suicide, Accident and Murder in Nineteenth Century Philadelphia. Cambridge: Harvard University Press.

Larson, C. (1984) Crime, Justice and Society. Bayside: General Hall. 
Levitt, S. (1994) "Why do increased arrest rates appear to reduce crime: deterrence, incapacitation or measurement error?," NBER working paper \# 5268.

Murphy, K.M., A. Shleifer and R. Vishney (1993) "Why is Rent Seeking So Costly to Growth?" American Economic Review 83: 409-414.

Murphy, K. M., A. Shleifer and R. Vishny (1991) "The allocation of talent: implications for growth," Quarterly Journal of Economics CVI: 503-530.

Pirenne, H. (1929) Medieval Cities. Princeton: Princeton University Press.

Putnam, R. (1993) Making Democracy Work: Civic Traditions in Modern Italy. Princeton: Princeton University Press.

Radzinowicz, L. and M. Wolfgang (1977) Crime and Justice. New York: Basic Books.

Sah, R. (1990) "Social Osmosis and the Returns to Crime," Journal of Political Economy 98.

Schichor, D., Decker, D. and R. O'Brien (1979) "Population Density and Criminal Victimization," Criminology: 180-200.

Weston, P. and K. Well (1993) Criminal Investigation: Basic Perspectives. New York: Prentice Hall.

Wilson, J. Q. and R. Herrstein (1980) Crime and Human Nature. New York: Simon and Schuster.

Wirth, L. (1938) "Urbanism as a Way of Life," American Journal of Sociology XLIV: 1-24. 
Table 1A:

1989 National Crime Victimization Survey Data Means by SMSA and non-SMSA

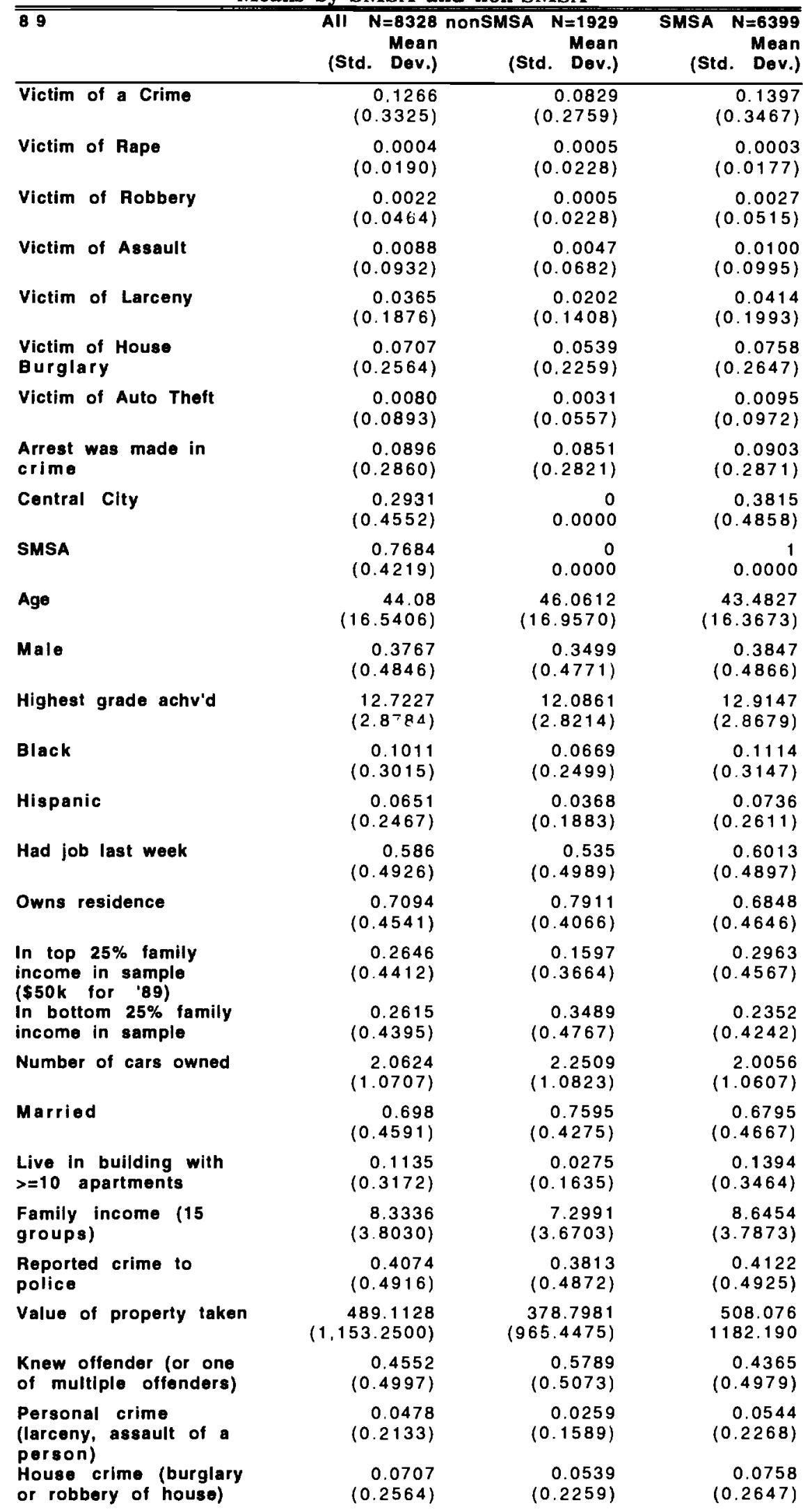

Whole sample sizes for arrest made, report to police, value taken, knew offender are 346, 1048, 709, 145. For SMSA for same variables: 47, 160, 104, 19. 
Table 1B:

1980 National Crime Victimization Survey Data

Means and Standard Deviations by SMSA and non-SMSA

\begin{tabular}{|c|c|c|c|}
\hline \multirow[t]{2}{*}{80} & $N=5274$ & $\begin{array}{r}\text { non-SMSA } \\
N=1211\end{array}$ & $\begin{array}{r}\text { SMSA } \\
N=4063\end{array}$ \\
\hline & $\begin{array}{l}\text { Mean } \\
\text { (Std. Dev.) }\end{array}$ & $\begin{array}{r}\text { Mean } \\
\text { (Std. Dev.) }\end{array}$ & $\begin{array}{r}\text { Mean } \\
\text { (Std. Dev.) }\end{array}$ \\
\hline$\overline{\text { SMSA }}$ & $\begin{array}{r}0.3394 \\
(0.4736)\end{array}$ & $\begin{array}{r}0 \\
0.0000\end{array}$ & $\begin{array}{r}0.4406 \\
(0.4965)\end{array}$ \\
\hline Age & $\begin{array}{r}35.4187 \\
(15.3569)\end{array}$ & $\begin{array}{r}35.4344 \\
(16.1409)\end{array}$ & $\begin{array}{r}35.414 \\
(15.1174)\end{array}$ \\
\hline Male & $\begin{array}{r}0.4702 \\
(0.4992)\end{array}$ & $\begin{array}{r}0.474 \\
(0.4995)\end{array}$ & $\begin{array}{r}0.4691 \\
(0.4991)\end{array}$ \\
\hline Highest grade achvid & $\begin{array}{r}16.0757 \\
(6.3169)\end{array}$ & $\begin{array}{r}14.9405 \\
(6.0652)\end{array}$ & $\begin{array}{r}16.414 \\
(6.3517)\end{array}$ \\
\hline Black & $\begin{array}{r}0.1033 \\
(0.3044)\end{array}$ & $\begin{array}{r}0.0537 \\
(0.2255)\end{array}$ & $\begin{array}{r}0.1181 \\
(0.3228)\end{array}$ \\
\hline Had job last week & $\begin{array}{r}0.6159 \\
(0.4864)\end{array}$ & $\begin{array}{r}0.597 \\
(0.4907)\end{array}$ & $\begin{array}{r}0.6215 \\
(0.4851)\end{array}$ \\
\hline Owns residence & $\begin{array}{r}0.5645 \\
(0.4959)\end{array}$ & $\begin{array}{r}0.5929 \\
(0.4915)\end{array}$ & $\begin{array}{r}0.556 \\
(0.4969)\end{array}$ \\
\hline $\begin{array}{l}\text { In top } 25 \% \text { family } \\
\text { income in sample } \\
\text { (\$50k for ' } 89 \text { ) }\end{array}$ & $\begin{array}{r}0.2332 \\
(0.4229)\end{array}$ & $\begin{array}{r}0.1462 \\
(0.3534)\end{array}$ & $\begin{array}{r}0.2592 \\
(0.4382)\end{array}$ \\
\hline Number of cars own & $\begin{array}{r}2.0425 \\
(1.1721)\end{array}$ & $\begin{array}{r}2.1924 \\
(1.1784)\end{array}$ & $\begin{array}{r}1.9978 \\
(1.1667)\end{array}$ \\
\hline Married & $\begin{array}{r}0.5061 \\
(0.5000)\end{array}$ & $\begin{array}{r}0.5557 \\
(0.4971)\end{array}$ & $\begin{array}{r}0.4913 \\
(0.5000)\end{array}$ \\
\hline $\begin{array}{l}\text { Live in building with } \\
>=10 \text { apartments }\end{array}$ & $\begin{array}{r}0.1801 \\
(0.3843)\end{array}$ & $\begin{array}{r}0.0801 \\
(0.2716)\end{array}$ & $\begin{array}{r}0.2099 \\
(0.4073)\end{array}$ \\
\hline $\begin{array}{l}\text { Family income (15 } \\
\text { groups) }\end{array}$ & $\begin{array}{r}9.8614 \\
(3.0401)\end{array}$ & $\begin{array}{r}9.0652 \\
(3.2190)\end{array}$ & $\begin{array}{r}10.0987 \\
(2.9437)\end{array}$ \\
\hline $\begin{array}{l}\text { Reported crime to } \\
\text { police }\end{array}$ & $\begin{array}{r}0.3877 \\
(0.4873)\end{array}$ & $\begin{array}{r}0.374 \\
(0.4841)\end{array}$ & $\begin{array}{r}0.3919 \\
(0.4882)\end{array}$ \\
\hline $\begin{array}{l}\text { Knew offender (or one } \\
\text { of multiple offenders) }\end{array}$ & $\begin{array}{r}0.4764 \\
(0.4997)\end{array}$ & $\begin{array}{r}0.6158 \\
(0.4876)\end{array}$ & $\begin{array}{r}0.4376 \\
(0.4964)\end{array}$ \\
\hline Value of property taken & $\begin{array}{r}374.9943 \\
(1,229.2700)\end{array}$ & $\begin{array}{r}244.1516 \\
(826.4073)\end{array}$ & $\begin{array}{r}413.904 \\
1323.290\end{array}$ \\
\hline $\begin{array}{l}\text { Personal crime } \\
\text { (larceny, assault of a } \\
\text { person) }\end{array}$ & $\begin{array}{r}0.7708 \\
(0.4204)\end{array}$ & $\begin{array}{r}0.7878 \\
(0.4090)\end{array}$ & $\begin{array}{r}0.7657 \\
(0.4236)\end{array}$ \\
\hline $\begin{array}{l}\text { House crime (burglary } \\
\text { or robbery of house) }\end{array}$ & $\begin{array}{r}0.1923 \\
(0.3941)\end{array}$ & $\begin{array}{r}0.1833 \\
(0.3871)\end{array}$ & $\begin{array}{r}0.1949 \\
(0.3962)\end{array}$ \\
\hline
\end{tabular}

Source: National Crime Victimization Survey, 1980 data.

Whole sample sizes for report crime, knew offender, value taken: $5179,932,3512$

For these variables for SMSA: 1198, 203, 805. 
Table 1C:

National Crime Victimization Survey Data

Probit of (Was a Victim) on Individual and Family Characteristics



NCS data from 1989 3rd quarter. Victims experienced crime during 6 months prior to interview. Implied elasticity of "victim" w/ respect to city size is calculated from the differing coefficients on the city size dummies. We regress $\log$ (coefficient) on $\log$ (city size) where city size=mid-point of the population range. 
Table 1D:

National Crime Victimization Survey Data

Probit of (Was a Victim) on Individual and Family Characteristics

\begin{tabular}{|c|c|c|c|c|c|c|}
\hline & $\begin{array}{r}(1) \\
\text { Victim of } \\
\text { a crime }\end{array}$ & $\begin{array}{r}\text { ( } 2) \\
\text { Victim of } \\
\text { personal } \\
\text { crime }\end{array}$ & $\begin{array}{r}\text { (3) } \\
\text { Victim of } \\
\text { personal } \\
\text { crime }\end{array}$ & $\begin{array}{r}\text { (4) } \\
\text { Victim of } \\
\text { house } \\
\text { crime }\end{array}$ & $\begin{array}{r}\text { Victim of } \\
\text { house } \\
\text { crime }\end{array}$ & $\begin{array}{r}(6) \\
\text { Victim of } \\
\text { assault }\end{array}$ \\
\hline Intercept & $\begin{array}{r}-0.9018 \\
(0.1756)\end{array}$ & $\begin{array}{r}-1.5425 \\
(0.2351)\end{array}$ & $\begin{array}{r}-1.5869 \\
(0.2461)\end{array}$ & $\begin{array}{c}-1.1212 \\
(0.1959)\end{array}$ & $\begin{array}{r}-1.1343 \\
(0.2025)\end{array}$ & $\begin{array}{r}-1.2378 \\
(0.4312)\end{array}$ \\
\hline SMSA & $\begin{array}{r}0.2104 \\
(0.0724)\end{array}$ & $\begin{array}{r}0.1768 \\
(0.0716)\end{array}$ & $\begin{array}{r}0.2262 \\
(0.1103)\end{array}$ & $\begin{array}{r}0.1260 \\
(0.0562)\end{array}$ & $\begin{array}{r}0.1407 \\
(0.0829)\end{array}$ & $\begin{array}{r}0.2500 \\
(0.1422)\end{array}$ \\
\hline Age & $\begin{array}{r}-0.0074 \\
(0.0014)\end{array}$ & $\begin{array}{r}-0.0083 \\
(0.0019)\end{array}$ & $\begin{array}{r}-0.0083 \\
(0.0019)\end{array}$ & $\begin{array}{r}-0.0052 \\
(0.0016)\end{array}$ & $\begin{array}{r}.0 .0052 \\
(0.0016)\end{array}$ & $\begin{array}{r}.0 .0148 \\
(0.0038)\end{array}$ \\
\hline Male & $\begin{array}{r}0.0757 \\
(0.0390)\end{array}$ & $\begin{array}{r}0.1113 \\
(0.0527)\end{array}$ & $\begin{array}{r}0.1118 \\
(0.0528)\end{array}$ & $\begin{array}{r}0.0052 \\
(0.0458)\end{array}$ & $\begin{array}{r}0.0057 \\
(0.0458)\end{array}$ & $\begin{array}{r}0.2802 \\
(0.0993)\end{array}$ \\
\hline Highest grade achv'd & $\begin{array}{r}0.0269 \\
(0.0075)\end{array}$ & $\begin{array}{r}0.0431 \\
(0.0104)\end{array}$ & $\begin{array}{r}0.0433 \\
(0.0104)\end{array}$ & $\begin{array}{r}0.0087 \\
(0.0087)\end{array}$ & $\begin{array}{r}0.0087 \\
(0.0087)\end{array}$ & $\begin{array}{r}-0.0183 \\
(0.0189)\end{array}$ \\
\hline Black & $\begin{array}{r}0.0490 \\
(0.0589)\end{array}$ & $\begin{array}{r}-0.3669 \\
(0.0946)\end{array}$ & $\begin{array}{r}-0.3681 \\
(0.0946)\end{array}$ & $\begin{array}{r}0.2349 \\
(0.0639)\end{array}$ & $\begin{array}{r}0.2337 \\
(0.0640)\end{array}$ & $\begin{array}{r}-0.4656 \\
(0.1821)\end{array}$ \\
\hline Hispanic & $\begin{array}{r}0.0596 \\
(0.0726)\end{array}$ & $\begin{array}{r}0.0729 \\
(0.0946)\end{array}$ & $\begin{array}{r}0.0728 \\
(0.0947)\end{array}$ & $\begin{array}{r}-0.0051 \\
(0.0873)\end{array}$ & $\begin{array}{r}-0.0050 \\
(0.0873)\end{array}$ & $\begin{array}{r}-0.0344 \\
(0.1618)\end{array}$ \\
\hline Had job last week & $\begin{array}{r}0.0513 \\
(0.0433)\end{array}$ & $\begin{array}{r}0.1009 \\
(0.0606)\end{array}$ & $\begin{array}{r}0.1013 \\
(0.0606)\end{array}$ & $\begin{array}{r}0.0096 \\
(0.0500)\end{array}$ & $\begin{array}{r}0.0098 \\
(0.0500)\end{array}$ & $\begin{array}{r}0.0016 \\
(0.1128)\end{array}$ \\
\hline Owns residence & $\begin{array}{r}-0.2982 \\
(0.0483)\end{array}$ & $\begin{array}{r}-0.2397 \\
(0.0660)\end{array}$ & $\begin{array}{r}-0.2379 \\
(0.0661)\end{array}$ & $\begin{array}{r}-0.2376 \\
(0.0560)\end{array}$ & $\begin{array}{r}-0.2368 \\
(0.0560)\end{array}$ & $\begin{array}{r}-0.3268 \\
(0.1204)\end{array}$ \\
\hline $\begin{array}{l}\text { In top } 25 \% \text { family } \\
\text { income in sample } \\
\text { ( } \$ 50 k \text { for } 189 \text { ) }\end{array}$ & $\begin{array}{r}0.1941 \\
(0.1369)\end{array}$ & $\begin{array}{r}0.3043 \\
(0.1011)\end{array}$ & $\begin{array}{r}0.4400 \\
(0.1906)\end{array}$ & $\begin{array}{r}-0.0082 \\
(0.0849)\end{array}$ & $\begin{array}{r}0.0685 \\
(0.1603)\end{array}$ & $\begin{array}{r}0.0466 \\
(0.2006)\end{array}$ \\
\hline $\begin{array}{l}\text { In bottom } 25 \% \text { family } \\
\text { income in sample }\end{array}$ & $\begin{array}{r}0.0527 \\
(0.1203)\end{array}$ & $\begin{array}{r}-0.0415 \\
(0.1229)\end{array}$ & $\begin{array}{r}-0.0028 \\
(0.1749)\end{array}$ & $\begin{array}{r}0.1076 \\
(0.1018)\end{array}$ & $\begin{array}{r}0.1106 \\
(0.1368)\end{array}$ & $\begin{array}{r}0.1477 \\
(0.2209)\end{array}$ \\
\hline Married & $\begin{array}{r}-0.4130 \\
(0.0413)\end{array}$ & $\begin{array}{r}-0.3419 \\
(0.0561)\end{array}$ & $\begin{array}{r}-0.3403 \\
(0.0562)\end{array}$ & $\begin{array}{l}-0.3271 \\
(0.0481)\end{array}$ & $\begin{array}{r}-0.3272 \\
(0.0481)\end{array}$ & $\begin{array}{r}-0.2922 \\
(0.1040)\end{array}$ \\
\hline $\begin{array}{l}\text { Family income (15 } \\
\text { groups) }\end{array}$ & $\begin{array}{r}-0.0260 \\
(0.0142)\end{array}$ & $\begin{array}{r}-0.0430 \\
(0.0197)\end{array}$ & $\begin{array}{r}-0.0433 \\
(0.0197)\end{array}$ & $\begin{array}{r}-0.0102 \\
(0.0163)\end{array}$ & $\begin{array}{r}.0 .0102 \\
(0.0163)\end{array}$ & $\begin{array}{r}-0.0139 \\
(0.0357)\end{array}$ \\
\hline Number of cars own & $\begin{array}{r}0.0350 \\
(0.0199)\end{array}$ & $\begin{array}{r}-0.0029 \\
(0.0273)\end{array}$ & $\begin{array}{r}-0.0028 \\
(0.0273)\end{array}$ & $\begin{array}{r}0.0189 \\
(0.0232)\end{array}$ & $\begin{array}{r}0.0189 \\
(0.0232)\end{array}$ & $\begin{array}{r}-0.1266 \\
(0.0538)\end{array}$ \\
\hline $\begin{array}{l}\text { Live in building with } \\
>=10 \text { apartments }\end{array}$ & $\begin{array}{r}0.1739 \\
(0.0570)\end{array}$ & $\begin{array}{r}0.3384 \\
(0.0704)\end{array}$ & $\begin{array}{r}0.3372 \\
(0.0704)\end{array}$ & $\begin{array}{r}-0.0638 \\
(0.0688)\end{array}$ & $\begin{array}{r}-0.0647 \\
(0.0688)\end{array}$ & $\begin{array}{r}-0.1014 \\
(0.1265)\end{array}$ \\
\hline SMSA*Iow income & $\begin{array}{r}0.0140 \\
(0.1052)\end{array}$ & & $\begin{array}{r}-0.0453 \\
(0.1557)\end{array}$ & & $\begin{array}{r}-0.0018 \\
(0.1184)\end{array}$ & \\
\hline SMSA*high income & $\begin{array}{r}-0.0944 \\
(0.1349)\end{array}$ & & $\begin{array}{r}-0.1549 \\
(0.1853)\end{array}$ & & $\begin{array}{r}-0.0891 \\
(0.1595)\end{array}$ & \\
\hline Ln (L) & -2892 & -1426 & -1426 & -2018 & -2018 & -362 \\
\hline $1-\operatorname{Ln}\left(L / L_{0}\right)$ & .09 & 11 & .11 & 05 & .05 & .13 \\
\hline $\mathbf{N}$ & 8328 & 8328 & 8328 & 8328 & 8328 & 8328 \\
\hline
\end{tabular}

Personal crime defined as theft from person, or rape, or assault. House crime defined as burglary from residence. 
Table 1E:

National Crime Victimization Survey Data OLS of Value of Property Taken

\begin{tabular}{|c|c|c|c|c|c|c|}
\hline & $\begin{array}{r}\text { Log(value } \\
\text { taken) } \\
1989 \\
\end{array}$ & $\begin{array}{r}\text { Log(value } \\
\text { taken) } \\
1980\end{array}$ & $\begin{array}{r}\text { Log(value } \\
\text { taken) } \\
1980 \\
\end{array}$ & $\begin{array}{r}\log (\text { value } \\
\text { taken) } \\
1980 \\
\end{array}$ & 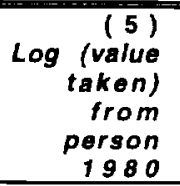 & $\begin{array}{r}(6) \\
\log (\text { value } \\
\text { taken) } \\
\text { from } \\
\text { house } \\
1980 \\
\end{array}$ \\
\hline Intercept & $\begin{array}{r}3.9629 \\
(0.3070)\end{array}$ & $\begin{array}{r}3.3719 \\
(0.1435)\end{array}$ & $\begin{array}{r}3.4740 \\
(0.1504)\end{array}$ & $\begin{array}{r}3.1966 \\
(0.3008)\end{array}$ & $\begin{array}{r}3.3309 \\
(0.1370)\end{array}$ & $\begin{array}{r}3.8179 \\
(0.3736)\end{array}$ \\
\hline SMSA & $\begin{array}{r}0.2610 \\
(0.2011)\end{array}$ & $\begin{array}{r}0.2038 \\
(0.0752)\end{array}$ & & & $\begin{array}{r}0.0951 \\
(0.0716)\end{array}$ & $\begin{array}{r}0.3389 \\
(0.1949)\end{array}$ \\
\hline Age & $\begin{array}{r}-0.0023 \\
(0.0046)\end{array}$ & $\begin{array}{r}-0.0001 \\
(0.0021)\end{array}$ & $\begin{array}{r}-0.0010 \\
(0.0021)\end{array}$ & $\begin{array}{r}0.0002 \\
(0.0023)\end{array}$ & $\begin{array}{r}-0.0039 \\
(0.0020)\end{array}$ & $\begin{array}{r}0.0004 \\
(0.0049)\end{array}$ \\
\hline Male & $\begin{array}{r}0.0860 \\
(0.1429)\end{array}$ & $\begin{array}{r}0.2258 \\
(0.0622)\end{array}$ & $\begin{array}{r}0.2156 \\
(0.0619)\end{array}$ & $\begin{array}{r}0.2238 \\
(0.0647)\end{array}$ & $\begin{array}{r}0.2585 \\
(0.0597)\end{array}$ & $\begin{array}{r}0.0019 \\
(0.1580)\end{array}$ \\
\hline Highest grade achv'd & & & & $\begin{array}{r}-0.0048 \\
(0.0052)\end{array}$ & & \\
\hline Black & $\begin{array}{r}0.4270 \\
(0.2091)\end{array}$ & $\begin{array}{r}0.5481 \\
(0.1063)\end{array}$ & $\begin{array}{r}0.3985 \\
(0.1084)\end{array}$ & $\begin{array}{r}0.5532 \\
(0.1072)\end{array}$ & $\begin{array}{r}0.4958 \\
(0.1065)\end{array}$ & $\begin{array}{r}0.3742 \\
(0.2359)\end{array}$ \\
\hline Hispanic & $\begin{array}{r}0.4662 \\
(0.2558)\end{array}$ & & & & & \\
\hline Married & $\begin{array}{r}-0.1357 \\
(0.1521)\end{array}$ & $\begin{array}{r}-0.0824 \\
(0.0681)\end{array}$ & $\begin{array}{r}-0.0544 \\
(0.0678)\end{array}$ & $\begin{array}{r}-0.0641 \\
(0.0694)\end{array}$ & $\begin{array}{r}-0.0466 \\
(0.0659)\end{array}$ & $\begin{array}{l}-0.1289 \\
(0.1695)\end{array}$ \\
\hline $\begin{array}{l}\text { Family income (15 } \\
\text { groups) }\end{array}$ & $\begin{array}{r}0.0541 \\
(0.0189)\end{array}$ & $\begin{array}{r}0.0437 \\
(0.0116)\end{array}$ & $\begin{array}{r}0.0449 \\
(0.0114)\end{array}$ & $\begin{array}{r}0.0423 \\
(0.0271)\end{array}$ & $\begin{array}{r}0.0284 \\
(0.0111)\end{array}$ & $\begin{array}{r}0.1190 \\
(0.0297)\end{array}$ \\
\hline Had job last woek & & & & $\begin{array}{r}-0.0052 \\
(0.0688)\end{array}$ & & \\
\hline Owns residence & & & & $\begin{array}{r}0.0037 \\
(0.0820)\end{array}$ & & \\
\hline High income & & & & $\begin{array}{r}0.2873 \\
(0.1993)\end{array}$ & & \\
\hline Number of cars own & & & & $\begin{array}{r}0.0608 \\
(0.0311)\end{array}$ & & \\
\hline Low income & & & & $\begin{array}{r}0.1445 \\
(0.2006)\end{array}$ & & \\
\hline $\begin{array}{l}\text { Live in building with } \\
>=10 \text { apartments }\end{array}$ & & & & $\begin{array}{r}0.2444 \\
(0.0959)\end{array}$ & & \\
\hline SMSA*high income & & & & $\begin{array}{r}0.0927 \\
(0.1783)\end{array}$ & & \\
\hline SMSA"middle income & & & & $\begin{array}{r}0.2022 \\
(0.0999)\end{array}$ & & \\
\hline SMSA*low income & & & & $\begin{array}{r}0.2256 \\
(0.1485)\end{array}$ & & \\
\hline City pop 1,000-9,999 & & & $\begin{array}{r}-0.0767 \\
(0.1041)\end{array}$ & & & \\
\hline $\begin{array}{l}\text { City pop } 10,000- \\
24,999\end{array}$ & & & $\begin{array}{r}-0.0549 \\
(0.1092)\end{array}$ & & & \\
\hline $\begin{array}{l}\text { City pop } 25,000- \\
49,999\end{array}$ & & & $\begin{array}{r}-0.0846 \\
(0.1164)\end{array}$ & & & \\
\hline $\begin{array}{l}\text { City pop } 50,000- \\
99,999\end{array}$ & & & $\begin{array}{r}0.1501 \\
(0.1161)\end{array}$ & & & \\
\hline $\begin{array}{l}\text { City pop } 100,000- \\
249,999\end{array}$ & & & $\begin{array}{r}-0.0132 \\
(0.1183)\end{array}$ & & & \\
\hline $\begin{array}{l}\text { City pop 250,000- } \\
499,999\end{array}$ & & & $\begin{array}{r}0.1931 \\
(0.1373)\end{array}$ & & & \\
\hline $\begin{array}{l}\text { City pop } 500,000- \\
999,999\end{array}$ & & & $\begin{array}{r}0.1844 \\
(0.1364)\end{array}$ & & & \\
\hline City pop $>=1,000,000$ & & & $\begin{array}{r}0.8515 \\
(0.1273)\end{array}$ & & & \\
\hline $\begin{array}{l}\text { Implied elasticity of } \\
\text { "victim" }\end{array}$ & & & .075 & & & \\
\hline $\mathbf{R}^{2}$ & .02 & .02 & .03 & .02 & .02 & 04 \\
\hline $\mathbf{N}$ & 705 & 3498 & 3498 & 3498 & 2796 & 577 \\
\hline
\end{tabular}


Table 1F:

National Crime Victimization Survey Data

Probits of Whether or Not Reported Crime to Police and Whether or Not Knew Offender

\begin{tabular}{|c|c|c|c|c|c|}
\hline & $\begin{array}{r}\text { Reported } \\
\text { crime to } \\
\text { police } \\
1989\end{array}$ & $\begin{array}{r}\text { Reported } \\
\text { crime to } \\
\text { pollice } \\
1980\end{array}$ & $\begin{array}{r}\text { Reported } \\
\text { crime to } \\
\text { police } \\
1980 \\
\end{array}$ & $\begin{array}{r}\text { Knew } \\
\text { offender } \\
1980\end{array}$ & $\begin{array}{r}\text { Knew } \\
\text { offender } \\
1980\end{array}$ \\
\hline Intercept & $\begin{array}{r}-0.5407 \\
(0.2495)\end{array}$ & $\begin{array}{r}-0.6934 \\
(0.0848)\end{array}$ & $\begin{array}{r}-0.5904 \\
(0.0798)\end{array}$ & $\begin{array}{r}1.0547 \\
(0.1913)\end{array}$ & $\begin{array}{r}0.9930 \\
(0.1738)\end{array}$ \\
\hline SMSA & & & $\begin{array}{r}0.0349 \\
(0.0431)\end{array}$ & & $\begin{array}{r}-0.4444 \\
(0.1055)\end{array}$ \\
\hline Age & $\begin{array}{r}0.0051 \\
(0.0028)\end{array}$ & $\begin{array}{r}0.0049 \\
(0.0012)\end{array}$ & $\begin{array}{r}0.0049 \\
(0.0012)\end{array}$ & $\begin{array}{r}-0.0093 \\
(0.0031)\end{array}$ & $\begin{array}{r}-0.0107 \\
(0.0031)\end{array}$ \\
\hline Male & $\begin{array}{r}-0.1055 \\
(0.0815)\end{array}$ & $\begin{array}{r}0.0001 \\
(0.0358)\end{array}$ & $\begin{array}{r}-0.0047 \\
(0.0357)\end{array}$ & $\begin{array}{r}-0.2785 \\
(0.0870)\end{array}$ & $\begin{array}{r}-0.2813 \\
(0.0854)\end{array}$ \\
\hline Highest grade achv'd & $\begin{array}{r}-0.0098 \\
(0.0156)\end{array}$ & & & & \\
\hline Black & $\begin{array}{r}-0.0311 \\
(0.1198)\end{array}$ & $\begin{array}{r}0.1173 \\
(0.0614)\end{array}$ & $\begin{array}{r}0.1313 \\
(0.0596)\end{array}$ & $\begin{array}{r}0.3368 \\
(0.1466)\end{array}$ & $\begin{array}{r}0.1431 \\
(0.1372)\end{array}$ \\
\hline Hispanic & $\begin{array}{r}0.1442 \\
(0.1556)\end{array}$ & & & & \\
\hline Married & $\begin{array}{r}-0.0670 \\
(0.0877)\end{array}$ & $\begin{array}{r}0.0497 \\
(0.0392)\end{array}$ & $\begin{array}{r}0.0477 \\
(0.0390)\end{array}$ & $\begin{array}{r}-0.2572 \\
(0.0970)\end{array}$ & $\begin{array}{r}-0.2031 \\
(0.0952)\end{array}$ \\
\hline $\begin{array}{l}\text { Family income (15 } \\
\text { groups) }\end{array}$ & $\begin{array}{r}0.0270 \\
(0.0117)\end{array}$ & $\begin{array}{r}0.0091 \\
(0.0064)\end{array}$ & $\begin{array}{r}0.0070 \\
(0.0065)\end{array}$ & $\begin{array}{r}-0.0315 \\
(0.0140)\end{array}$ & $\begin{array}{r}-0.0170 \\
(0.0140)\end{array}$ \\
\hline City pop 1,000-9,999 & $\begin{array}{r}.0 .0904 \\
(0.1545)\end{array}$ & $\begin{array}{r}0.2189 \\
(0.0607)\end{array}$ & & $\begin{array}{r}0.1937 \\
(0.1505)\end{array}$ & \\
\hline $\begin{array}{l}\text { City pop 10,000- } \\
24,999\end{array}$ & $\begin{array}{r}0.0609 \\
(0.1439)\end{array}$ & $\begin{array}{r}0.1661 \\
(0.0643)\end{array}$ & & $\begin{array}{r}-0.3833 \\
(0.1593)\end{array}$ & \\
\hline $\begin{array}{l}\text { City pop 25,000- } \\
49,999\end{array}$ & $\begin{array}{r}0.3486 \\
(0.1481)\end{array}$ & $\begin{array}{r}(.0436 \\
(0.0682)\end{array}$ & & $\begin{array}{r}-0.4418 \\
(0.1760)\end{array}$ & \\
\hline $\begin{array}{l}\text { City pop 50,000- } \\
99,999\end{array}$ & $\begin{array}{r}0.2803 \\
(0.1489)\end{array}$ & $\begin{array}{r}0.1830 \\
(0.0678)\end{array}$ & & $\begin{array}{r}-0.5196 \\
(0.1700)\end{array}$ & \\
\hline $\begin{array}{l}\text { City pop } 100,000- \\
249,999\end{array}$ & $\begin{array}{r}0.1163 \\
(0.1441)\end{array}$ & $\begin{array}{r}0.1498 \\
(0.0672)\end{array}$ & & $\begin{array}{r}-0.3447 \\
(0.1600)\end{array}$ & \\
\hline $\begin{array}{l}\text { City pop 250,000- } \\
499,999\end{array}$ & $\begin{array}{r}0.1473 \\
(0.1803)\end{array}$ & $\begin{array}{r}0.1292 \\
(0.0794)\end{array}$ & & $\begin{array}{r}-0.7480 \\
(0.1763)\end{array}$ & \\
\hline $\begin{array}{l}\text { City pop } 500,000- \\
999,999\end{array}$ & $\begin{array}{r}0.0997 \\
(0.1677)\end{array}$ & $\begin{array}{r}0.0472 \\
(0.0769)\end{array}$ & & $\begin{array}{r}-0.5568 \\
(0.1762)\end{array}$ & \\
\hline City pop >= $1,000,000$ & $\begin{array}{r}0.1426 \\
(0.1532)\end{array}$ & $\begin{array}{r}0.1801 \\
(0.0720)\end{array}$ & & $\begin{array}{r}-0.9149 \\
(0.1664)\end{array}$ & \\
\hline $\begin{array}{l}\text { Implied elasticity of } \\
\text { "report" (or "knew") } \\
\text { w/ respect to city size } \\
\text { Ln (L) }\end{array}$ & -698 & -3433 & -3443 & -592 & -614 \\
\hline $1-\operatorname{Ln}\left(L / L_{0}\right)$ & .01 & .01 & .01 & .08 & .05 \\
\hline $\mathbf{N}$ & 1048 & 5179 & 5179 & 932 & 932 \\
\hline
\end{tabular}

Implied elasticity of "report" $w /$ respect to city size is calculated from the differing coefficients on the city size dummies. We regress $\log$ (coefficient) on $\log$ (city size) where city size $=$ mid-point of the population range. For "knew off" we use $\log \left(-1^{*}\right.$ coefficient $)$ and then take $-1^{*}$ calculated elasticity. 
Table 2A:

National Longitudinal Survey of Youth Data-- Means

\begin{tabular}{|c|c|c|c|}
\hline NLSY & $\begin{array}{r}\text { A II } \\
\mathrm{N}=9145 \\
\text { Mean } \\
\text { (Std. Dev.) }\end{array}$ & $\begin{array}{r}\text { non-SMSA } \\
\mathrm{N}=2872 \\
\\
\text { Mean } \\
\text { (Std. Dev.) }\end{array}$ & $\begin{array}{r}\text { SMSA } \\
N=6273 \\
\text { Mean } \\
\text { (Std. Dev.) }\end{array}$ \\
\hline$\overline{\text { Age }}$ & $\begin{array}{r}20.3623 \\
(2.2244)\end{array}$ & $\begin{array}{r}20.2862 \\
(2.2146)\end{array}$ & $\begin{array}{r}20.3971 \\
(2.2282)\end{array}$ \\
\hline SMSA & $\begin{array}{r}0.6859 \\
(0.4642)\end{array}$ & $\begin{array}{r}0 \\
0.0000\end{array}$ & $\begin{array}{r}1 \\
0.0000\end{array}$ \\
\hline $\begin{array}{l}\text { Stole something }<\$ 50 \text { in } \\
\text { past year }\end{array}$ & $\begin{array}{r}0.1847 \\
(0.3881)\end{array}$ & $\begin{array}{r}0.1588 \\
(0.3655)\end{array}$ & $\begin{array}{r}0.1966 \\
(0.3974)\end{array}$ \\
\hline Shoplitted in past year & $\begin{array}{r}0.2657 \\
(0.4417)\end{array}$ & $\begin{array}{r}0.2211 \\
(0.4151)\end{array}$ & $\begin{array}{r}0.2861 \\
(0.4520)\end{array}$ \\
\hline $\begin{array}{l}\text { Fought at school or } \\
\text { work in past yr. }\end{array}$ & $\begin{array}{r}0.2753 \\
(0.4467)\end{array}$ & $\begin{array}{r}0.2761 \\
(0.4472)\end{array}$ & $\begin{array}{r}0.275 \\
(0.4465)\end{array}$ \\
\hline $\begin{array}{l}\text { Attacked someone with } \\
\text { intent to injure in past } \\
\text { y r. } \\
\text { Attends church >= once } \\
\text { per month }\end{array}$ & $\begin{array}{r}0.1024 \\
(0.3031) \\
0.5578 \\
(0.4967)\end{array}$ & $\begin{array}{r}0.1034 \\
(0.3045) \\
\\
0.586 \\
(0.4926)\end{array}$ & $\begin{array}{r}0.1019 \\
(0.3025) \\
\\
0.5449 \\
(0.4980)\end{array}$ \\
\hline $\begin{array}{l}\text { Family intact (mother } \\
\text { father) }\end{array}$ & $\begin{array}{r}0.703 \\
(0.4570)\end{array}$ & $\begin{array}{r}0.7305 \\
(0.4438)\end{array}$ & $\begin{array}{r}0.6904 \\
(0.4624)\end{array}$ \\
\hline $\begin{array}{l}\text { Mother worked when } \\
\text { respondent was age } 14\end{array}$ & $\begin{array}{r}0.5268 \\
(0.4993)\end{array}$ & $\begin{array}{r}0.5366 \\
(0.4987)\end{array}$ & $\begin{array}{r}0.5224 \\
(0.4995)\end{array}$ \\
\hline $\begin{array}{l}\text { Highest grade mother } \\
\text { achv'd }\end{array}$ & $\begin{array}{r}10.8622 \\
(3.2130)\end{array}$ & $\begin{array}{r}10.4631 \\
(3.1281)\end{array}$ & $\begin{array}{r}11.045 \\
(3.2350)\end{array}$ \\
\hline Highest grade achv'd & $\begin{array}{r}10.3902 \\
(2.0338)\end{array}$ & $\begin{array}{r}10.2336 \\
(2.0168)\end{array}$ & $\begin{array}{r}10.4618 \\
(2.0376)\end{array}$ \\
\hline Male & $\begin{array}{r}0.4769 \\
(0.4995)\end{array}$ & $\begin{array}{r}0.4795 \\
(0.4997)\end{array}$ & $\begin{array}{r}0.4757 \\
(0.4994)\end{array}$ \\
\hline $\begin{array}{l}\text { Local unemployment } \\
\text { rate }\end{array}$ & $\begin{array}{r}2.5562 \\
(0.7348)\end{array}$ & $\begin{array}{r}2.7671 \\
(0.8428)\end{array}$ & $\begin{array}{r}2.4596 \\
(0.6576)\end{array}$ \\
\hline $\begin{array}{l}\text { North (regional } \\
\text { dummy) }\end{array}$ & $\begin{array}{r}0.1875 \\
(0.3904)\end{array}$ & $\begin{array}{r}0.0815 \\
(0.2736)\end{array}$ & $\begin{array}{r}0.2361 \\
(0.4247)\end{array}$ \\
\hline $\begin{array}{l}\text { South (regional } \\
\text { dummy) }\end{array}$ & $\begin{array}{r}0.3601 \\
(0.4801)\end{array}$ & $\begin{array}{r}0.524 \\
(0.4995)\end{array}$ & $\begin{array}{r}0.285 \\
(0.4515)\end{array}$ \\
\hline $\begin{array}{l}\text { Central (regional } \\
\text { dummy) }\end{array}$ & $\begin{array}{r}0.2568 \\
(0.4369)\end{array}$ & $\begin{array}{r}0.2413 \\
(0.4279)\end{array}$ & $\begin{array}{r}0.2638 \\
(0.4407)\end{array}$ \\
\hline Black & $\begin{array}{r}0.2472 \\
(0.4314)\end{array}$ & $\begin{array}{r}0.2263 \\
(0.4185)\end{array}$ & $\begin{array}{r}0.2568 \\
(0.4369)\end{array}$ \\
\hline Hispanic & $\begin{array}{r}0.1622 \\
(0.3686)\end{array}$ & $\begin{array}{r}0.1062 \\
(0.3081)\end{array}$ & $\begin{array}{r}0.1878 \\
(0.3906)\end{array}$ \\
\hline $\begin{array}{l}\text { Number times used } \\
\text { marijuana in past year }\end{array}$ & $\begin{array}{r}1.8013 \\
(2.3242)\end{array}$ & $\begin{array}{r}1.446 \\
(2.1774)\end{array}$ & $\begin{array}{r}1.964 \\
(2.3708)\end{array}$ \\
\hline AFQT Score & $\begin{array}{r}41.0389 \\
(28.8994)\end{array}$ & $\begin{array}{r}39.3311 \\
(28.6152)\end{array}$ & $\begin{array}{r}41.8208 \\
(28.9973)\end{array}$ \\
\hline $\begin{array}{l}\text { Age first had sexual } \\
\text { intercourse }\end{array}$ & $\begin{array}{r}17.2766 \\
(2.0117)\end{array}$ & $\begin{array}{r}17.1699 \\
(1.9097)\end{array}$ & $\begin{array}{r}17.3249 \\
(2.0547)\end{array}$ \\
\hline $\begin{array}{l}\text { Has a savings account or } \\
\text { similar }\end{array}$ & $\begin{array}{r}0.6271 \\
(0.4836)\end{array}$ & $\begin{array}{r}0.6088 \\
(0.4881)\end{array}$ & $\begin{array}{r}0.6356 \\
(0.4813)\end{array}$ \\
\hline $\begin{array}{l}\text { Age started drinking >= } \\
\text { once per week }\end{array}$ & $\begin{array}{r}17.0283 \\
(2.0955)\end{array}$ & $\begin{array}{r}16.9473 \\
(1.9354)\end{array}$ & $\begin{array}{r}17.0635 \\
(2.1606)\end{array}$ \\
\hline $\begin{array}{l}\text { Age first smoked } \\
\text { cigarette }\end{array}$ & $\begin{array}{r}13.5119 \\
(3.2916)\end{array}$ & $\begin{array}{r}13.4041 \\
(3.3317)\end{array}$ & $\begin{array}{r}13.5607 \\
(3.2725)\end{array}$ \\
\hline $\begin{array}{l}\text { Has sex without birth } \\
\text { control }\end{array}$ & $\begin{array}{r}0.3276 \\
(0.4694)\end{array}$ & $\begin{array}{r}0.3082 \\
(0.4620)\end{array}$ & $\begin{array}{r}0.3362 \\
(0.4725)\end{array}$ \\
\hline $\begin{array}{l}\text { SMSA at age } 14 \text {, but } \\
\text { non-SMSA now }\end{array}$ & $\begin{array}{r}0.1925 \\
(0.3942)\end{array}$ & $\begin{array}{r}0.6128 \\
(0.4872)\end{array}$ & $\begin{array}{r}0 \\
0.0000\end{array}$ \\
\hline $\begin{array}{l}\text { Changed city/town of } \\
\text { residence since birth }\end{array}$ & $\begin{array}{r}0.5496 \\
(0.4976)\end{array}$ & $\begin{array}{r}0.5129 \\
(0.4999)\end{array}$ & $\begin{array}{r}0.5664 \\
(0.4956)\end{array}$ \\
\hline $\begin{array}{l}\text { Ever been charged w/ a } \\
\text { crime }\end{array}$ & $\begin{array}{r}0.0933 \\
(0.2908)\end{array}$ & $\begin{array}{r}0.0769 \\
(0.2666)\end{array}$ & $\begin{array}{r}0.1007 \\
(0.3010)\end{array}$ \\
\hline $\begin{array}{l}\text { Ever been stopped by } \\
\text { police }\end{array}$ & $\begin{array}{r}0.1751 \\
(0.3800)\end{array}$ & $\begin{array}{r}0.1368 \\
(0.3437)\end{array}$ & $\begin{array}{r}0.1926 \\
(0.3944)\end{array}$ \\
\hline Ever been convicted & $\begin{array}{r}0.0525 \\
(0.2230)\end{array}$ & $\begin{array}{r}0.0529 \\
(0.2239)\end{array}$ & $\begin{array}{r}0.0523 \\
(0.2226)\end{array}$ \\
\hline $\begin{array}{l}\text { Had income from } \\
\text { criminal activity in } \\
\text { past yr. }\end{array}$ & $\begin{array}{r}0.0374 \\
(0.1897)\end{array}$ & $\begin{array}{r}0.0317 \\
(0.1752)\end{array}$ & $\begin{array}{r}0.04 \\
(0.1960)\end{array}$ \\
\hline
\end{tabular}


Table 2B:

National Longitudinal Survey of Youth Data

Probits of (Whether or Not Respondent Reports Having Stolen) on Individual and Family Characteristics

\begin{tabular}{|c|c|c|c|c|c|}
\hline & $\begin{array}{r}(1) \\
\text { stolen } \\
\text { property } \\
<\$ 50\end{array}$ & $\begin{array}{r}(2) \\
\text { stoien } \\
\text { property } \\
<\$ 50\end{array}$ & $\begin{array}{r}(3) \\
\text { stolon } \\
\text { property } \\
<\$ 50\end{array}$ & $\begin{array}{r}(4) \\
\text { stolen } \\
\text { property } \\
<\$ 50\end{array}$ & $\begin{array}{r}(5) \\
\text { stolon } \\
\text { property } \\
<\$ 50\end{array}$ \\
\hline Intercept & $\begin{array}{r}-0.9146 \\
(0.0430)\end{array}$ & $\begin{array}{r}-1.3281 \\
(1.4908)\end{array}$ & $\begin{array}{r}-2.3740 \\
(1.5177)\end{array}$ & $\begin{array}{r}0.0913 \\
(1.5629)\end{array}$ & $\begin{array}{l}-2.4230 \\
(1.5184)\end{array}$ \\
\hline SMSA & $\begin{array}{r}0.1085 \\
(0.0346)\end{array}$ & $\begin{array}{r}0.1304 \\
(0.0374)\end{array}$ & $\begin{array}{r}0.1856 \\
(0.0541)\end{array}$ & $\begin{array}{r}0.1163 \\
(0.0557)\end{array}$ & $\begin{array}{r}0.2910 \\
(0.1026)\end{array}$ \\
\hline $\begin{array}{l}\text { SMSA at age } 14 \text {, but } \\
\text { non-SMSA now }\end{array}$ & & & $\begin{array}{r}0.1114 \\
(0.0602)\end{array}$ & $\begin{array}{r}0.0932 \\
(0.0619)\end{array}$ & $\begin{array}{r}0.1167 \\
(0.0605)\end{array}$ \\
\hline $\begin{array}{l}\text { Changed city/town of } \\
\text { residence since birth }\end{array}$ & & & $\begin{array}{r}-0.0436 \\
(0.0325)\end{array}$ & $\begin{array}{r}-0.0587 \\
(0.0334)\end{array}$ & $\begin{array}{r}-0.0438 \\
(0.0325)\end{array}$ \\
\hline $\begin{array}{l}\text { Number times used } \\
\text { marijuana in past year }\end{array}$ & & & & $\begin{array}{r}0.1476 \\
(0.0069)\end{array}$ & \\
\hline Black*SMSA & & & & & $\begin{array}{r}-0.0876 \\
(0.0942)\end{array}$ \\
\hline Family intact*SMSA & & & & & $\begin{array}{r}-0.0652 \\
(0.0798)\end{array}$ \\
\hline AFQT*SMSA & & & & & $\begin{array}{r}-0.0009 \\
(0.0013)\end{array}$ \\
\hline Age & & $\begin{array}{r}0.0479 \\
(0.1478)\end{array}$ & $\begin{array}{r}0.1396 \\
(0.1499)\end{array}$ & $\begin{array}{r}-0.1104 \\
(0.1545)\end{array}$ & $\begin{array}{r}0.1365 \\
(0.1500)\end{array}$ \\
\hline Age squared & & $\begin{array}{r}-0.0023 \\
(0.0036)\end{array}$ & $\begin{array}{r}-0.0041 \\
(0.0036)\end{array}$ & $\begin{array}{r}0.0015 \\
(0.0037)\end{array}$ & $\begin{array}{r}-0.0041 \\
(0.0036)\end{array}$ \\
\hline $\begin{array}{l}\text { Local unemployment } \\
\text { rate }\end{array}$ & & $\begin{array}{r}-0.0283 \\
(0.0237)\end{array}$ & $\begin{array}{r}-0.0213 \\
(0.0238)\end{array}$ & $\begin{array}{r}-0.0276 \\
(0.0245)\end{array}$ & $\begin{array}{r}-0.0202 \\
(0.0240)\end{array}$ \\
\hline $\begin{array}{l}\text { Family intact (mother } \\
\text { \& father) }\end{array}$ & & $\begin{array}{r}-0.0757 \\
(0.0354)\end{array}$ & $\begin{array}{r}-0.0776 \\
(0.0361)\end{array}$ & $\begin{array}{r}-0.0160 \\
(0.0372)\end{array}$ & $\begin{array}{l}-0.0298 \\
(0.0682)\end{array}$ \\
\hline Highest grade achv'd & & $\begin{array}{r}0.0350 \\
(0.0132)\end{array}$ & $\begin{array}{r}-0.0036 \\
(0.0152)\end{array}$ & $\begin{array}{r}-0.0083 \\
(0.0157)\end{array}$ & $\begin{array}{r}-0.0035 \\
(0.0152)\end{array}$ \\
\hline Male & & $\begin{array}{r}0.4969 \\
(0.0315)\end{array}$ & $\begin{array}{r}0.4819 \\
(0.0317)\end{array}$ & $\begin{array}{r}0.4474 \\
(0.0326)\end{array}$ & $\begin{array}{r}0.4819 \\
(0.0317)\end{array}$ \\
\hline Black & & $\begin{array}{r}-0.2195 \\
(0.0410)\end{array}$ & $\begin{array}{r}-0.1324 \\
(0.0458)\end{array}$ & $\begin{array}{r}-0.0465 \\
(0.0471)\end{array}$ & $\begin{array}{r}-0.0683 \\
(0.0834)\end{array}$ \\
\hline Hispanic & & $\begin{array}{r}-0.1996 \\
(0.0475)\end{array}$ & $\begin{array}{r}-0.0914 \\
(0.0520)\end{array}$ & $\begin{array}{r}-0.0381 \\
(0.0537)\end{array}$ & $\begin{array}{r}-0.0967 \\
(0.0523)\end{array}$ \\
\hline $\begin{array}{l}\text { Highest grade mother } \\
\text { achv'd }\end{array}$ & & & $\begin{array}{r}0.0156 \\
(0.0061)\end{array}$ & $\begin{array}{r}0.0081 \\
(0.0063)\end{array}$ & $\begin{array}{r}0.0157 \\
(0.0061)\end{array}$ \\
\hline $\begin{array}{l}\text { Mother worked when } \\
\text { respondent was age } 14\end{array}$ & & & $\begin{array}{r}0.0249 \\
(0.0319)\end{array}$ & $\begin{array}{r}-0.0026 \\
(0.0328)\end{array}$ & $\begin{array}{r}0.0241 \\
(0.0319)\end{array}$ \\
\hline AFQT Score & & & $\begin{array}{r}0.0029 \\
(0.0007)\end{array}$ & $\begin{array}{r}0.0031 \\
(0.0008)\end{array}$ & $\begin{array}{r}0.0035 \\
(0.0012)\end{array}$ \\
\hline $\begin{array}{l}\text { Altends church >= once } \\
\text { per month }\end{array}$ & & & $\begin{array}{r}-0.1105 \\
(0.0324)\end{array}$ & $\begin{array}{r}0.0058 \\
(0.0339)\end{array}$ & $\begin{array}{r}-0.1105 \\
(0.0324)\end{array}$ \\
\hline $\begin{array}{l}\text { North (regional } \\
\text { dummy) }\end{array}$ & $\begin{array}{r}-0.0208 \\
(0.0483)\end{array}$ & $\begin{array}{r}-0.0517 \\
(0.0506)\end{array}$ & $\begin{array}{r}-0.0545 \\
(0.0510)\end{array}$ & $\begin{array}{r}-0.0305 \\
(0.0525)\end{array}$ & $\begin{array}{r}-0.0546 \\
(0.0510)\end{array}$ \\
\hline $\begin{array}{l}\text { South (regional } \\
\text { dummy) }\end{array}$ & $\begin{array}{r}-0.1747 \\
(0.0435)\end{array}$ & $\begin{array}{r}-0.1680 \\
(0.0486)\end{array}$ & $\begin{array}{r}.0 .1446 \\
(0.0491)\end{array}$ & $\begin{array}{r}-0.0743 \\
(0.0506)\end{array}$ & $\begin{array}{r}-0.1450 \\
(0.0492)\end{array}$ \\
\hline $\begin{array}{l}\text { Central (regional } \\
\text { dummy) }\end{array}$ & $\begin{array}{r}0.0160 \\
(0.0447)\end{array}$ & $\begin{array}{r}-0.0447 \\
(0.0484)\end{array}$ & $\begin{array}{r}-0.0420 \\
(0.0489)\end{array}$ & $\begin{array}{r}0.0095 \\
(0.0504)\end{array}$ & $\begin{array}{r}-0.0414 \\
(0.0490)\end{array}$ \\
\hline $\operatorname{Ln}(L)$ & -4351 & .4196 & -4172 & -3939 & -4172 \\
\hline $1-\operatorname{Ln}\left(L / L_{0}\right)$ & .01 & .04 & .05 & .10 & .05 \\
\hline $\mathbf{N}$ & 9145 & 9145 & 9145 & 9145 & 9145 \\
\hline
\end{tabular}


Table 2C:

National Longitudinal Survey of Youth Data

Probits of (Whether or Not Respondent Reports Having Shoplifted) on Individual and Family Characteristics

\begin{tabular}{|c|c|c|c|c|c|}
\hline & $\begin{array}{r}\text { (1) } \\
\text { Shoplifted } \\
\text { in past } \\
\text { year }\end{array}$ & $\begin{array}{r}(2) \\
\text { Shoplifted } \\
\text { in past } \\
\text { year }\end{array}$ & $\begin{array}{r}(3) \\
\text { Shoplifted } \\
\text { in past } \\
\text { year }\end{array}$ & $\begin{array}{r}(4) \\
\text { Shoplifted } \\
\text { in past } \\
\text { year }\end{array}$ & $\begin{array}{r}(5) \\
\text { Shoplifted } \\
\text { in past } \\
\text { year }\end{array}$ \\
\hline Intercept & $\begin{array}{r}-0.6167 \\
(0.0395)\end{array}$ & $\begin{array}{r}-5.0036 \\
(1.3796)\end{array}$ & $\begin{array}{r}-4.6366 \\
(1.4033)\end{array}$ & $\begin{array}{r}-1.7933 \\
(1.4543)\end{array}$ & $\begin{array}{r}-4.6750 \\
(1.4046)\end{array}$ \\
\hline SMSA & $\begin{array}{r}0.1576 \\
(0.0321)\end{array}$ & $\begin{array}{r}0.1599 \\
(0.0343)\end{array}$ & $\begin{array}{r}0.1913 \\
(0.0490)\end{array}$ & $\begin{array}{r}0.1072 \\
(0.0509)\end{array}$ & $\begin{array}{r}0.3768 \\
(0.0926)\end{array}$ \\
\hline $\begin{array}{l}\text { SMSA at age } 14 \text {, but } \\
\text { non-SMSA now }\end{array}$ & & & $\begin{array}{r}0.0603 \\
(0.0547)\end{array}$ & $\begin{array}{r}0.0327 \\
(0.0568)\end{array}$ & $\begin{array}{r}0.0595 \\
(0.0550)\end{array}$ \\
\hline $\begin{array}{l}\text { Changed city/town of } \\
\text { residence since birth }\end{array}$ & & & $\begin{array}{r}0.0137 \\
(0.0298)\end{array}$ & $\begin{array}{r}-0.0003 \\
(0.0309)\end{array}$ & $\begin{array}{r}0.0123 \\
(0.0298)\end{array}$ \\
\hline $\begin{array}{l}\text { Number times used } \\
\text { marijuana in past year }\end{array}$ & & & & $\begin{array}{r}0.1852 \\
(0.0066)\end{array}$ & \\
\hline Black*SMSA & & & & & $\begin{array}{r}-0.0029 \\
(0.0849)\end{array}$ \\
\hline Family intact*SMSA & & & & & $\begin{array}{r}.0 .0275 \\
(0.0725)\end{array}$ \\
\hline AFQT"SMSA & & & & & $\begin{array}{r}-0.0041 \\
(0.0012)\end{array}$ \\
\hline Age & & $\begin{array}{r}0.4966 \\
(0.1370)\end{array}$ & $\begin{array}{r}0.4482 \\
(0.1388)\end{array}$ & $\begin{array}{r}0.1652 \\
(0.1439)\end{array}$ & $\begin{array}{r}0.4417 \\
(0.1389)\end{array}$ \\
\hline Age squared & & $\begin{array}{r}-0.0132 \\
(0.0033)\end{array}$ & $\begin{array}{r}-0.0123 \\
(0.0033)\end{array}$ & $\begin{array}{r}.0 .0060 \\
(0.0035)\end{array}$ & $\begin{array}{r}-0.0121 \\
(0.0033)\end{array}$ \\
\hline $\begin{array}{l}\text { Local unemployment } \\
\text { rate }\end{array}$ & & $\begin{array}{r}-0.0248 \\
(0.0215)\end{array}$ & $\begin{array}{r}-0.0237 \\
(0.0216)\end{array}$ & $\begin{array}{r}-0.0314 \\
(0.0224)\end{array}$ & $\begin{array}{r}-0.0286 \\
(0.0217)\end{array}$ \\
\hline $\begin{array}{l}\text { Family intact (mother } \\
\text { a father) }\end{array}$ & & $\begin{array}{r}.0 .1001 \\
(0.0321)\end{array}$ & $\begin{array}{r}.0 .0703 \\
(0.0327)\end{array}$ & $\begin{array}{r}-0.0001 \\
(0.0340)\end{array}$ & $\begin{array}{l}-0.0479 \\
(0.0620)\end{array}$ \\
\hline Highest grade achv'd & & $\begin{array}{r}-0.0109 \\
(0.0119)\end{array}$ & $\begin{array}{r}0.0042 \\
(0.0138)\end{array}$ & $\begin{array}{r}-0.0026 \\
(0.0144)\end{array}$ & $\begin{array}{r}0.0039 \\
(0.0138)\end{array}$ \\
\hline Male & & $\begin{array}{r}0.1948 \\
(0.0286)\end{array}$ & $\begin{array}{r}0.1883 \\
(0.0288)\end{array}$ & $\begin{array}{r}0.1351 \\
(0.0299)\end{array}$ & $\begin{array}{r}0.1903 \\
(0.0288)\end{array}$ \\
\hline Black & & $\begin{array}{r}-0.0866 \\
(0.0370)\end{array}$ & $\begin{array}{r}-0.1098 \\
(0.0413)\end{array}$ & $\begin{array}{r}-0.0040 \\
(0.0429)\end{array}$ & $\begin{array}{r}-0.1104 \\
(0.0756)\end{array}$ \\
\hline Hispanic & & $\begin{array}{r}-0.0440 \\
(0.0423)\end{array}$ & $\begin{array}{r}-0.0074 \\
(0.0466)\end{array}$ & $\begin{array}{r}0.0722 \\
(0.0484)\end{array}$ & $\begin{array}{r}-0.0193 \\
(0.0469)\end{array}$ \\
\hline $\begin{array}{l}\text { Highest grade mother } \\
\text { achv'd }\end{array}$ & & & $\begin{array}{r}0.0122 \\
(0.0055)\end{array}$ & $\begin{array}{r}0.0021 \\
(0.0057)\end{array}$ & $\begin{array}{r}0.0114 \\
(0.0055)\end{array}$ \\
\hline $\begin{array}{l}\text { Mother worked when } \\
\text { respondent was age } 14\end{array}$ & & & $\begin{array}{r}0.0597 \\
(0.0293)\end{array}$ & $\begin{array}{r}0.0288 \\
(0.0304)\end{array}$ & $\begin{array}{r}0.0598 \\
(0.0293)\end{array}$ \\
\hline AFQT Score & & & $\begin{array}{r}-0.0022 \\
(0.0007)\end{array}$ & $\begin{array}{r}-0.0025 \\
(0.0007)\end{array}$ & $\begin{array}{r}0.0007 \\
(0.0011)\end{array}$ \\
\hline $\begin{array}{l}\text { Attends church >= once } \\
\text { per month }\end{array}$ & & & $\begin{array}{r}-0.1594 \\
(0.0297)\end{array}$ & $\begin{array}{r}-0.0233 \\
(0.0313)\end{array}$ & $\begin{array}{l}-0.1609 \\
(0.0297)\end{array}$ \\
\hline $\begin{array}{l}\text { North (regional } \\
\text { dummy) }\end{array}$ & $\begin{array}{r}-0.0641 \\
(0.0447)\end{array}$ & $\begin{array}{r}-0.0609 \\
(0.0463)\end{array}$ & $\begin{array}{r}-0.0474 \\
(0.0466)\end{array}$ & $\begin{array}{r}-0.0133 \\
(0.0483)\end{array}$ & $\begin{array}{r}-0.0512 \\
(0.0466)\end{array}$ \\
\hline $\begin{array}{l}\text { South (regional } \\
\text { dummy) }\end{array}$ & $\begin{array}{r}.0 .2504 \\
(0.0400)\end{array}$ & $\begin{array}{r}-0.2506 \\
(0.0444)\end{array}$ & $\begin{array}{r}-0.2244 \\
(0.0449)\end{array}$ & $\begin{array}{r}-0.1444 \\
(0.0466)\end{array}$ & $\begin{array}{r}-0.2225 \\
(0.0449)\end{array}$ \\
\hline $\begin{array}{l}\text { Central (regional } \\
\text { dummy) }\end{array}$ & $\begin{array}{r}-0.0817 \\
(0.0415)\end{array}$ & $\begin{array}{r}-0.0941 \\
(0.0447)\end{array}$ & $\begin{array}{r}-0.0651 \\
(0.0451)\end{array}$ & $\begin{array}{r}-0.0023 \\
(0.0469)\end{array}$ & $\begin{array}{r}-0.0739 \\
(0.0452)\end{array}$ \\
\hline $\operatorname{Ln}(L)$ & -5249 & -5175 & .5151 & -4738 & -5144 \\
\hline $1-\operatorname{Ln}\left(L / L_{0}\right)$ & .01 & .02 & .03 & 11 & .03 \\
\hline $\mathbf{N}$ & 9145 & 9145 & 9145 & 9145 & 9145 \\
\hline
\end{tabular}


Table 2D:

NLSY: Probits of Other Measures of Criminal Activity on Individual and Family Characteristics

\begin{tabular}{|c|c|c|c|c|c|c|}
\hline & $\begin{array}{l}\text { Has income } \\
\text { from crime } \\
\text { in past yr. } \\
\end{array}$ & $\begin{array}{l}\text { Has income } \\
\text { from crime } \\
\text { in past yr. }\end{array}$ & $\begin{array}{r}\text { Ever } \\
\text { stopped by } \\
\text { pollice } \\
\end{array}$ & $\begin{array}{r}(4) \\
\text { Ever } \\
\text { stopped by } \\
\text { pollce } \\
\text { cond'l on } \\
\text { committed } \\
\text { crime }\end{array}$ & $\begin{array}{r}\text { Ever } \\
\text { charged } \\
\text { with a } \\
\text { crime }\end{array}$ & $\begin{array}{r}\text { Ever } \\
\text { convicted } \\
\end{array}$ \\
\hline Intercept & $\begin{array}{r}-2.6426 \\
(2.5331)\end{array}$ & $\begin{array}{r}-4.8382 \\
(3.5381)\end{array}$ & $\begin{array}{r}-5.9269 \\
(1.6024)\end{array}$ & $\begin{array}{r}-4.9287 \\
(2.4699)\end{array}$ & $\begin{array}{r}-10.7577 \\
(2.8820)\end{array}$ & $\begin{array}{r}-5.8525 \\
(3.3381)\end{array}$ \\
\hline SMSA & $\begin{array}{r}0.2276 \\
(0.0955)\end{array}$ & $\begin{array}{r}0.0409 \\
(0.1305)\end{array}$ & $\begin{array}{r}0.2603 \\
(0.0571)\end{array}$ & $\begin{array}{r}0.2101 \\
(0.0920)\end{array}$ & $\begin{array}{r}0.1271 \\
(0.1080)\end{array}$ & $\begin{array}{r}-0.1373 \\
(0.1180)\end{array}$ \\
\hline $\begin{array}{l}\text { SMSA at age } 14 \text {, but } \\
\text { non-SMSA now }\end{array}$ & $\begin{array}{r}0.1993 \\
(0.1043)\end{array}$ & $\begin{array}{r}-0.0140 \\
(0.1480)\end{array}$ & $\begin{array}{r}0.0624 \\
(0.0643)\end{array}$ & $\begin{array}{r}0.0166 \\
(0.1047)\end{array}$ & $\begin{array}{r}0.0609 \\
(0.1218)\end{array}$ & $\begin{array}{r}0.0077 \\
(0.1323)\end{array}$ \\
\hline $\begin{array}{l}\text { Changed city/town of } \\
\text { residence since birth }\end{array}$ & $\begin{array}{r}0.0756 \\
(0.0540)\end{array}$ & $\begin{array}{r}0.0785 \\
(0.0727)\end{array}$ & $\begin{array}{r}-0.0134 \\
(0.0340)\end{array}$ & $\begin{array}{r}0.0405 \\
(0.0515)\end{array}$ & $\begin{array}{r}0.0772 \\
(0.0596)\end{array}$ & $\begin{array}{r}0.1292 \\
(0.0701)\end{array}$ \\
\hline Age & $\begin{array}{r}0.1651 \\
(0.2529)\end{array}$ & $\begin{array}{r}0.4250 \\
(0.3527)\end{array}$ & $\begin{array}{r}0.4655 \\
(0.1580)\end{array}$ & $\begin{array}{r}0.4214 \\
(0.2443)\end{array}$ & $\begin{array}{r}1.0173 \\
(0.2843)\end{array}$ & $\begin{array}{r}0.5211 \\
(0.3291)\end{array}$ \\
\hline Age squared & $\begin{array}{r}-0.0045 \\
(0.0061)\end{array}$ & $\begin{array}{r}.0 .0105 \\
(0.0085)\end{array}$ & $\begin{array}{r}-0.0103 \\
(0.0038)\end{array}$ & $\begin{array}{r}-0.0093 \\
(0.0059)\end{array}$ & $\begin{array}{r}-0.0212 \\
(0.0068)\end{array}$ & $\begin{array}{r}-0.0100 \\
(0.0079)\end{array}$ \\
\hline $\begin{array}{l}\text { Local unemployment } \\
\text { rate }\end{array}$ & $\begin{array}{r}-0.0320 \\
(0.0397)\end{array}$ & $\begin{array}{r}-0.0393 \\
(0.0522)\end{array}$ & $\begin{array}{r}0.0076 \\
(0.0245)\end{array}$ & $\begin{array}{r}-0.0343 \\
(0.0367)\end{array}$ & $\begin{array}{r}-0.1456 \\
(0.0424)\end{array}$ & $\begin{array}{r}-0.1714 \\
(0.0487)\end{array}$ \\
\hline $\begin{array}{l}\text { Family intact (mother } \\
\text { \& father) }\end{array}$ & $\begin{array}{r}-0.0901 \\
(0.0560)\end{array}$ & $\begin{array}{r}-0.1362 \\
(0.0759)\end{array}$ & $\begin{array}{r}-0.1353 \\
(0.0370)\end{array}$ & $\begin{array}{r}-0.1401 \\
(0.0564)\end{array}$ & $\begin{array}{r}-0.2778 \\
(0.0628)\end{array}$ & $\begin{array}{r}-0.2096 \\
(0.0731)\end{array}$ \\
\hline Highest grade achv'd & $\begin{array}{r}-0.0564 \\
(0.0239)\end{array}$ & $\begin{array}{r}-0.0659 \\
(0.0355)\end{array}$ & $\begin{array}{r}-0.0441 \\
(0.0152)\end{array}$ & $\begin{array}{r}-0.0444 \\
(0.0252)\end{array}$ & $\begin{array}{r}-0.1332 \\
(0.0271)\end{array}$ & $\begin{array}{r}-0.0802 \\
(0.0309)\end{array}$ \\
\hline Male & $\begin{array}{r}0.4135 \\
(0.0539)\end{array}$ & $\begin{array}{r}0.4625 \\
(0.0765)\end{array}$ & $\begin{array}{r}0.8142 \\
(0.0340)\end{array}$ & $\begin{array}{r}0.7683 \\
(0.0527)\end{array}$ & $\begin{array}{r}0.7087 \\
(0.0626)\end{array}$ & $\begin{array}{r}0.7153 \\
(0.0762)\end{array}$ \\
\hline Black & $\begin{array}{r}0.0450 \\
(0.0691)\end{array}$ & $\begin{array}{r}0.1575 \\
(0.0951)\end{array}$ & $\begin{array}{r}-0.2286 \\
(0.0476)\end{array}$ & $\begin{array}{r}-0.1997 \\
(0.0735)\end{array}$ & $\begin{array}{r}-0.2975 \\
(0.0839)\end{array}$ & $\begin{array}{r}-0.3703 \\
(0.0992)\end{array}$ \\
\hline Hispanic & $\begin{array}{r}-0.2413 \\
(0.0902)\end{array}$ & $\begin{array}{r}-0.1618 \\
(0.1194)\end{array}$ & $\begin{array}{r}-0.0833 \\
(0.0529)\end{array}$ & $\begin{array}{r}-0.0833 \\
(0.0803)\end{array}$ & $\begin{array}{r}-0.2415 \\
(0.0931)\end{array}$ & $\begin{array}{r}-0.3118 \\
(0.1100)\end{array}$ \\
\hline $\begin{array}{l}\text { Highest grade mother } \\
\text { achv'd }\end{array}$ & $\begin{array}{r}0.0071 \\
(0.0100)\end{array}$ & $\begin{array}{r}0.0094 \\
(0.0142)\end{array}$ & $\begin{array}{r}0.0208 \\
(0.0063)\end{array}$ & $\begin{array}{r}0.0105 \\
(0.0099)\end{array}$ & $\begin{array}{r}-0.0102 \\
(0.0115)\end{array}$ & $\begin{array}{r}-0.0161 \\
(0.0134)\end{array}$ \\
\hline $\begin{array}{l}\text { Mother worked when } \\
\text { respondent was age } 14\end{array}$ & $\begin{array}{r}-0.0502 \\
(0.0532)\end{array}$ & $\begin{array}{r}-0.0612 \\
(0.0723)\end{array}$ & $\begin{array}{r}0.0630 \\
(0.0335)\end{array}$ & $\begin{array}{r}0.0539 \\
(0.0513)\end{array}$ & $\begin{array}{r}0.1719 \\
(0.0595)\end{array}$ & $\begin{array}{r}0.1152 \\
(0.0693)\end{array}$ \\
\hline AFQT Score & $\begin{array}{r}-0.0090 \\
(0.0013)\end{array}$ & $\begin{array}{r}-0.0078 \\
(0.0017)\end{array}$ & $\begin{array}{r}-0.0053 \\
(0.0008)\end{array}$ & $\begin{array}{r}-0.0059 \\
(0.0012)\end{array}$ & $\begin{array}{r}-0.0059 \\
(0.0014)\end{array}$ & $\begin{array}{l}-0.0078 \\
(0.0016)\end{array}$ \\
\hline $\begin{array}{l}\text { Attends church }>=\text { once } \\
\text { per month }\end{array}$ & $\begin{array}{r}-0.1327 \\
(0.0537)\end{array}$ & $\begin{array}{r}-0.1962 \\
(0.0740)\end{array}$ & $\begin{array}{r}-0.1669 \\
(0.0338)\end{array}$ & $\begin{array}{r}-0.1733 \\
(0.0520)\end{array}$ & $\begin{array}{r}-0.2749 \\
(0.0601)\end{array}$ & $\begin{array}{r}-0.1770 \\
(0.0705)\end{array}$ \\
\hline $\begin{array}{l}\text { North (regional } \\
\text { dummy) }\end{array}$ & $\begin{array}{r}-0.0596 \\
(0.0856)\end{array}$ & $\begin{array}{r}-0.1170 \\
(0.1108)\end{array}$ & $\begin{array}{l}-0.1933 \\
(0.0524)\end{array}$ & $\begin{array}{r}-0.1127 \\
(0.0781)\end{array}$ & $\begin{array}{r}-0.1898 \\
(0.0875)\end{array}$ & $\begin{array}{l}-0.3058 \\
(0.1025)\end{array}$ \\
\hline $\begin{array}{l}\text { South (regional } \\
\text { dummy) }\end{array}$ & $\begin{array}{r}-0.1962 \\
(0.0839)\end{array}$ & $\begin{array}{r}-0.2934 \\
(0.1121)\end{array}$ & $\begin{array}{r}-0.3168 \\
(0.0508)\end{array}$ & $\begin{array}{r}-0.2773 \\
(0.0772)\end{array}$ & $\begin{array}{r}-0.4501 \\
(0.0876)\end{array}$ & $\begin{array}{r}-0.5268 \\
(0.1014)\end{array}$ \\
\hline $\begin{array}{l}\text { Central (regional } \\
\text { dummy) }\end{array}$ & $\begin{array}{r}0.0719 \\
(0.0801)\end{array}$ & $\begin{array}{r}0.0325 \\
(0.1031)\end{array}$ & $\begin{array}{r}-0.1206 \\
(0.0503)\end{array}$ & $\begin{array}{r}-0.0750 \\
(0.0749)\end{array}$ & $\begin{array}{r}-0.2946 \\
(0.0846)\end{array}$ & $\begin{array}{r}-0.3905 \\
(0.0972)\end{array}$ \\
\hline $\operatorname{Ln}(L)$ & -1329 & -765 & -3795 & -1688 & -1226 & -860 \\
\hline $1-\operatorname{Ln}\left(L / L_{0}\right)$ & .09 & .09 & .11 & .09 & .13 & .13 \\
\hline $\mathbf{N}$ & 9145 & 3166 & 9145 & 3166 & 3166 & 3166 \\
\hline
\end{tabular}


Table 2E:

National Longitudinal Survey of Youth Data

Probits of (Whether or Not Respondent Reports Having Stolen) on Individual and Family Characteristics including Various Measures of Patience

\begin{tabular}{|c|c|c|c|c|c|}
\hline & $\begin{array}{r}(1) \\
\text { Stolen } \\
\text { property } \\
<\$ 50 \\
\text { in past yr. }\end{array}$ & $\begin{array}{r}(2) \\
\text { Stolen } \\
\text { proporty } \\
<\$ 50 \\
\text { in past yr. }\end{array}$ & $\begin{array}{r}(3) \\
\text { Stolen } \\
\text { property } \\
<\$ 50 \\
\text { in past } y r .\end{array}$ & $\begin{array}{r}(4) \\
\text { Stolen } \\
\text { property } \\
<\$ 50 \\
\text { in past yr. }\end{array}$ & $\begin{array}{r}(5) \\
\text { stolen } \\
\text { property } \\
<\$ 50 \\
\end{array}$ \\
\hline Intercept & $\begin{array}{r}-2.5535 \\
(1.7061)\end{array}$ & $\begin{array}{l}-2.3076 \\
(1.5507)\end{array}$ & $\begin{array}{r}-3.0112 \\
(1.5339)\end{array}$ & $\begin{array}{r}-3.3921 \\
(1.7547)\end{array}$ & $\begin{array}{r}-2.8796 \\
(2.1390)\end{array}$ \\
\hline SMSA & $\begin{array}{r}0.1756 \\
(0.0600)\end{array}$ & $\begin{array}{r}0.1690 \\
(0.0551)\end{array}$ & $\begin{array}{r}0.1797 \\
(0.0547)\end{array}$ & $\begin{array}{r}0.1520 \\
(0.0615)\end{array}$ & $\begin{array}{r}0.1650 \\
(0.0755)\end{array}$ \\
\hline Ago & $\begin{array}{r}0.2246 \\
(0.1671)\end{array}$ & $\begin{array}{r}0.1344 \\
(0.1532)\end{array}$ & $\begin{array}{r}0.1715 \\
(0.1514)\end{array}$ & $\begin{array}{r}0.2687 \\
(0.1717)\end{array}$ & $\begin{array}{r}0.2760 \\
(0.2092)\end{array}$ \\
\hline Age squared & $\begin{array}{r}-0.0064 \\
(0.0040)\end{array}$ & $\begin{array}{r}-0.0041 \\
(0.0037)\end{array}$ & $\begin{array}{r}-0.0045 \\
(0.0036)\end{array}$ & $\begin{array}{r}-0.0071 \\
(0.0041)\end{array}$ & $\begin{array}{r}-0.0075 \\
(0.0050)\end{array}$ \\
\hline $\begin{array}{l}\text { Local unemployment } \\
\text { rate }\end{array}$ & $\begin{array}{r}-0.0163 \\
(0.0260)\end{array}$ & $\begin{array}{r}-0.0226 \\
(0.0243)\end{array}$ & $\begin{array}{r}-0.0251 \\
(0.0240)\end{array}$ & $\begin{array}{r}.0 .0207 \\
(0.0266)\end{array}$ & $\begin{array}{r}-0.0094 \\
(0.0320)\end{array}$ \\
\hline $\begin{array}{l}\text { Family intact (mother } \\
\text { \& father) }\end{array}$ & $\begin{array}{r}-0.0487 \\
(0.0391)\end{array}$ & $\begin{array}{r}-0.0721 \\
(0.0370)\end{array}$ & $\begin{array}{r}-0.0667 \\
(0.0365)\end{array}$ & $\begin{array}{r}-0.0449 \\
(0.0403)\end{array}$ & $\begin{array}{r}-0.0159 \\
(0.0493)\end{array}$ \\
\hline Highest grade achv'd & $\begin{array}{r}.0 .0001 \\
(0.0165)\end{array}$ & $\begin{array}{r}0.0027 \\
(0.0157)\end{array}$ & $\begin{array}{r}-0.0032 \\
(0.0154)\end{array}$ & $\begin{array}{r}0.0018 \\
(0.0171)\end{array}$ & $\begin{array}{r}0.0136 \\
(0.0208)\end{array}$ \\
\hline Male & $\begin{array}{r}0.4584 \\
(0.0366)\end{array}$ & $\begin{array}{r}0.4800 \\
(0.0324)\end{array}$ & $\begin{array}{r}0.3616 \\
(0.0332)\end{array}$ & $\begin{array}{r}0.3578 \\
(0.0387)\end{array}$ & $\begin{array}{r}0.3213 \\
(0.0470)\end{array}$ \\
\hline Black & $\begin{array}{r}-0.1762 \\
(0.0500)\end{array}$ & $\begin{array}{r}-0.1328 \\
(0.0472)\end{array}$ & $\begin{array}{r}-0.1421 \\
(0.0463)\end{array}$ & $\begin{array}{r}-0.1737 \\
(0.0516)\end{array}$ & $\begin{array}{r}-0.1367 \\
(0.0655)\end{array}$ \\
\hline Hispanic & $\begin{array}{r}-0.0790 \\
(0.0581)\end{array}$ & $\begin{array}{r}-0.1041 \\
(0.0533)\end{array}$ & $\begin{array}{r}-0.0829 \\
(0.0526)\end{array}$ & $\begin{array}{r}-0.0790 \\
(0.0598)\end{array}$ & $\begin{array}{r}0.0229 \\
(0.0727)\end{array}$ \\
\hline $\begin{array}{l}\text { Highest grade mother } \\
\text { achv'd }\end{array}$ & $\begin{array}{r}0.0159 \\
(0.0069)\end{array}$ & $\begin{array}{r}0.0160 \\
(0.0063)\end{array}$ & $\begin{array}{r}0.0158 \\
(0.0062)\end{array}$ & $\begin{array}{r}0.0167 \\
(0.0071)\end{array}$ & $\begin{array}{r}0.0199 \\
(0.0086)\end{array}$ \\
\hline $\begin{array}{l}\text { Mother worked when } \\
\text { respondent was age } 14\end{array}$ & $\begin{array}{r}0.0097 \\
(0.0351)\end{array}$ & $\begin{array}{r}0.0265 \\
(0.0327)\end{array}$ & $\begin{array}{r}0.0313 \\
(0.0323)\end{array}$ & $\begin{array}{r}0.0148 \\
(0.0361)\end{array}$ & $\begin{array}{r}-0.0221 \\
(0.0431)\end{array}$ \\
\hline AFQT Score & $\begin{array}{r}0.0035 \\
(0.0008)\end{array}$ & $\begin{array}{r}0.0032 \\
(0.0008)\end{array}$ & $\begin{array}{r}0.0042 \\
(0.0007)\end{array}$ & $\begin{array}{r}0.0048 \\
(0.0009)\end{array}$ & $\begin{array}{r}0.0039 \\
(0.0010)\end{array}$ \\
\hline $\begin{array}{l}\text { Attends church >= once } \\
\text { per month }\end{array}$ & $\begin{array}{r}-0.0740 \\
(0.0358)\end{array}$ & $\begin{array}{r}-0.1055 \\
(0.0332)\end{array}$ & $\begin{array}{r}-0.0998 \\
(0.0328)\end{array}$ & $\begin{array}{r}-0.0701 \\
(0.0369)\end{array}$ & $\begin{array}{r}-0.0130 \\
(0.0444)\end{array}$ \\
\hline $\begin{array}{l}\text { SMSA at age } 14 \text {, but } \\
\text { non-SMSA now }\end{array}$ & $\begin{array}{r}0.0583 \\
(0.0667)\end{array}$ & $\begin{array}{r}0.0856 \\
(0.0613)\end{array}$ & $\begin{array}{r}0.1086 \\
(0.0609)\end{array}$ & $\begin{array}{r}0.0392 \\
(0.0683)\end{array}$ & $\begin{array}{r}0.0467 \\
(0.0837)\end{array}$ \\
\hline $\begin{array}{l}\text { Changed city/town of } \\
\text { residence since birth }\end{array}$ & $\begin{array}{r}-0.0147 \\
(0.0359)\end{array}$ & $\begin{array}{r}-0.0434 \\
(0.0332)\end{array}$ & $\begin{array}{r}-0.0512 \\
(0.0328)\end{array}$ & $\begin{array}{r}-0.0198 \\
(0.0368)\end{array}$ & $\begin{array}{r}0.0040 \\
(0.0440)\end{array}$ \\
\hline $\begin{array}{l}\text { Age first had sexual } \\
\text { intercourse }\end{array}$ & $\begin{array}{r}-0.0384 \\
(0.0082)\end{array}$ & & & $\begin{array}{r}-0.0327 \\
(0.0085)\end{array}$ & $\begin{array}{r}-0.0200 \\
(0.0107)\end{array}$ \\
\hline $\begin{array}{l}\text { Has a savings account or } \\
\text { similar }\end{array}$ & & $\begin{array}{r}-0.0641 \\
(0.0373)\end{array}$ & & $\begin{array}{r}-0.0167 \\
(0.0409)\end{array}$ & $\begin{array}{r}0.0111 \\
(0.0495)\end{array}$ \\
\hline $\begin{array}{l}\text { Fought at school or } \\
\text { work in past yr. }\end{array}$ & & & $\begin{array}{r}0.4780 \\
(0.0360)\end{array}$ & $\begin{array}{r}0.4375 \\
(0.0402)\end{array}$ & $\begin{array}{r}0.3062 \\
(0.0495)\end{array}$ \\
\hline $\begin{array}{l}\text { Has sex without birth } \\
\text { contral }\end{array}$ & & & & & $\begin{array}{r}0.0238 \\
(0.0576)\end{array}$ \\
\hline $\begin{array}{l}\text { Age started drinking >= } \\
\text { once per week }\end{array}$ & & & & & $\begin{array}{r}-0.0307 \\
(0.0109)\end{array}$ \\
\hline $\begin{array}{l}\text { Age first smoked } \\
\text { cigarette }\end{array}$ & & & & & $\begin{array}{r}-0.0290 \\
(0.0069)\end{array}$ \\
\hline $\begin{array}{l}\text { Attacked someone with } \\
\text { intent to injure in past } \\
\text { yr. } \\
\text { North (regional } \\
\text { dummy) }\end{array}$ & $\begin{array}{r}-0.0605 \\
(0.0560)\end{array}$ & $\begin{array}{r}-0.0476 \\
(0.0523)\end{array}$ & $\begin{array}{r}-0.0455 \\
(0.0515)\end{array}$ & $\begin{array}{r}-0.0544 \\
(0.0577)\end{array}$ & $\begin{array}{r}0.3074 \\
(0.0615) \\
0.0287 \\
(0.0687)\end{array}$ \\
\hline $\begin{array}{l}\text { South (regional } \\
\text { dummy) }\end{array}$ & $\begin{array}{r}-0.1423 \\
(0.0540)\end{array}$ & $\begin{array}{r}-0.1644 \\
(0.0503)\end{array}$ & $\begin{array}{r}-0.1467 \\
(0.0497)\end{array}$ & $\begin{array}{r}-0.1546 \\
(0.0554)\end{array}$ & $\begin{array}{r}-0.1343 \\
(0.0674)\end{array}$ \\
\hline $\begin{array}{l}\text { Central (regional } \\
\text { dummy) }\end{array}$ & $\begin{array}{r}-0.0285 \\
(0.0536)\end{array}$ & $\begin{array}{r}-0.0576 \\
(0.0501)\end{array}$ & $\begin{array}{l}-0.0384 \\
(0.0494)\end{array}$ & $\begin{array}{r}-0.0289 \\
(0.0551)\end{array}$ & $\begin{array}{r}0.0093 \\
(0.0656)\end{array}$ \\
\hline $\operatorname{Ln}(L)$ & -3479 & -3972 & -4085 & -3293 & -2322 \\
\hline $1 \cdot \operatorname{Ln}\left(L / L_{0}\right)$ & .05 & .05 & .07 & .07 & .07 \\
\hline $\mathbf{N}$ & 7435 & 8703 & 9145 & 7143 & 4712 \\
\hline
\end{tabular}


Table 2F:

National Longitudinal Survey of Youth Data

Probits of (Whether or Not Respondent Reports Having Shoplifted) on Individual and Family Characteristics including Various Measures of Patience

\begin{tabular}{|c|c|c|c|c|c|}
\hline & $\begin{array}{r}(1) \\
\text { Shoplifted } \\
\text { in past } \\
\text { year }\end{array}$ & $\begin{array}{r}(2) \\
\text { Shoplifted } \\
\text { in past } \\
\text { year }\end{array}$ & $\begin{array}{r}\text { ( } 3) \\
\text { Shoplifted } \\
\text { in past } \\
\text { year }\end{array}$ & $\begin{array}{r}(4) \\
\text { Shopllfted } \\
\text { in past } \\
\text { year }\end{array}$ & $\begin{array}{r}(5) \\
\text { Shoplifted } \\
\text { in past } \\
\text { year }\end{array}$ \\
\hline Intercept & $\begin{array}{r}-2.6183 \\
(1.5734)\end{array}$ & $\begin{array}{r}-4.2660 \\
(1.4357)\end{array}$ & $\begin{array}{r}-5.7849 \\
(1.4324)\end{array}$ & $\begin{array}{r}-4.1416 \\
(1.6359)\end{array}$ & $\begin{array}{r}-2.9949 \\
(2.0172)\end{array}$ \\
\hline SMSA & $\begin{array}{r}0.1744 \\
(0.0544)\end{array}$ & $\begin{array}{r}0.2019 \\
(0.0503)\end{array}$ & $\begin{array}{r}0.1822 \\
(0.0500)\end{array}$ & $\begin{array}{r}0.1817 \\
(0.0567)\end{array}$ & $\begin{array}{r}0.1742 \\
(0.0704)\end{array}$ \\
\hline Age & $\begin{array}{r}0.3438 \\
(0.1543)\end{array}$ & $\begin{array}{r}0.4112 \\
(0.1421)\end{array}$ & $\begin{array}{r}0.5178 \\
(0.1416)\end{array}$ & $\begin{array}{r}0.4296 \\
(0.1603)\end{array}$ & $\begin{array}{r}0.3480 \\
(0.1974)\end{array}$ \\
\hline Age squared & $\begin{array}{r}-0.0102 \\
(0.0037)\end{array}$ & $\begin{array}{r}-0.0115 \\
(0.0034)\end{array}$ & $\begin{array}{r}-0.0135 \\
(0.0034)\end{array}$ & $\begin{array}{r}-0.0118 \\
(0.0038)\end{array}$ & $\begin{array}{r}-0.0102 \\
(0.0047)\end{array}$ \\
\hline $\begin{array}{l}\text { Local unemployment } \\
\text { rate }\end{array}$ & $\begin{array}{r}-0.0328 \\
(0.0236)\end{array}$ & $\begin{array}{r}-0.0198 \\
(0.0220)\end{array}$ & $\begin{array}{r}-0.0277 \\
(0.0220)\end{array}$ & $\begin{array}{r}-0.0285 \\
(0.0244)\end{array}$ & $\begin{array}{r}-0.0298 \\
(0.0299)\end{array}$ \\
\hline $\begin{array}{l}\text { Family intact (mother } \\
\text { \& father) }\end{array}$ & $\begin{array}{r}-0.0051 \\
(0.0356)\end{array}$ & $\begin{array}{r}-0.0678 \\
(0.0336)\end{array}$ & $\begin{array}{r}-0.0590 \\
(0.0334)\end{array}$ & $\begin{array}{r}-0.0029 \\
(0.0371)\end{array}$ & $\begin{array}{r}0.0002 \\
(0.0459)\end{array}$ \\
\hline Highest grade achv'd & $\begin{array}{r}0.0094 \\
(0.0150)\end{array}$ & $\begin{array}{r}0.0138 \\
(0.0143)\end{array}$ & $\begin{array}{r}0.0085 \\
(0.0142)\end{array}$ & $\begin{array}{r}0.0162 \\
(0.0157)\end{array}$ & $\begin{array}{r}0.0392 \\
(0.0196)\end{array}$ \\
\hline Male & $\begin{array}{r}0.1048 \\
(0.0333)\end{array}$ & $\begin{array}{r}0.1791 \\
(0.0295)\end{array}$ & $\begin{array}{r}0.0028 \\
(0.0307)\end{array}$ & $\begin{array}{r}-0.0663 \\
(0.0359)\end{array}$ & $\begin{array}{l}-0.1131 \\
(0.0438)\end{array}$ \\
\hline Black & $\begin{array}{r}-0.1379 \\
(0.0451)\end{array}$ & $\begin{array}{r}-0.1123 \\
(0.0427)\end{array}$ & $\begin{array}{r}.0 .1376 \\
(0.0422)\end{array}$ & $\begin{array}{r}-0.1456 \\
(0.0472)\end{array}$ & $\begin{array}{r}-0.1200 \\
(0.0607)\end{array}$ \\
\hline Hispanic & $\begin{array}{r}0.0533 \\
(0.0521)\end{array}$ & $\begin{array}{r}-0.0207 \\
(0.0478)\end{array}$ & $\begin{array}{r}0.0067 \\
(0.0476)\end{array}$ & $\begin{array}{r}0.0498 \\
(0.0541)\end{array}$ & $\begin{array}{r}0.1408 \\
(0.0671)\end{array}$ \\
\hline $\begin{array}{l}\text { Highest grade mother } \\
\text { achv'd }\end{array}$ & $\begin{array}{r}0.0133 \\
(0.0062)\end{array}$ & $\begin{array}{r}0.0114 \\
(0.0057)\end{array}$ & $\begin{array}{r}0.0122 \\
(0.0056)\end{array}$ & $\begin{array}{r}0.0123 \\
(0.0064)\end{array}$ & $\begin{array}{r}0.0164 \\
(0.0079)\end{array}$ \\
\hline $\begin{array}{l}\text { Mother worked when } \\
\text { respondent was age } 14\end{array}$ & $\begin{array}{r}0.0366 \\
(0.0321)\end{array}$ & $\begin{array}{r}0.0567 \\
(0.0300)\end{array}$ & $\begin{array}{r}0.0686 \\
(0.0298)\end{array}$ & $\begin{array}{r}0.0399 \\
(0.0334)\end{array}$ & $\begin{array}{l}-0.0143 \\
(0.0405)\end{array}$ \\
\hline AFQT Score & $\begin{array}{r}-0.0009 \\
(0.0008)\end{array}$ & $\begin{array}{r}-0.0021 \\
(0.0007)\end{array}$ & $\begin{array}{r}-0.0005 \\
(0.0007)\end{array}$ & $\begin{array}{r}0.0004 \\
(0.0008)\end{array}$ & $\begin{array}{r}-0.0007 \\
(0.0010)\end{array}$ \\
\hline $\begin{array}{l}\text { Attends church }>=\text { once } \\
\text { per month }\end{array}$ & $\begin{array}{r}-0.1191 \\
(0.0328)\end{array}$ & $\begin{array}{r}-0.1607 \\
(0.0305)\end{array}$ & $\begin{array}{r}-0.1468 \\
(0.0303)\end{array}$ & $\begin{array}{r}-0.1196 \\
(0.0341)\end{array}$ & $\begin{array}{r}-0.1079 \\
(0.0415)\end{array}$ \\
\hline $\begin{array}{l}\text { SMSA at age } 14 \text {, but } \\
\text { non-SMSA now }\end{array}$ & $\begin{array}{r}0.0463 \\
(0.0604)\end{array}$ & $\begin{array}{r}0.0682 \\
(0.0560)\end{array}$ & $\begin{array}{r}0.0514 \\
(0.0558)\end{array}$ & $\begin{array}{r}0.0577 \\
(0.0628)\end{array}$ & $\begin{array}{r}0.1153 \\
(0.0774)\end{array}$ \\
\hline $\begin{array}{l}\text { Changed city/town of } \\
\text { residence since birth }\end{array}$ & $\begin{array}{r}0.0294 \\
(0.0328)\end{array}$ & $\begin{array}{r}0.0070 \\
(0.0305)\end{array}$ & $\begin{array}{r}0.0047 \\
(0.0304)\end{array}$ & $\begin{array}{r}0.0209 \\
(0.0340)\end{array}$ & $\begin{array}{r}0.0253 \\
(0.0411)\end{array}$ \\
\hline $\begin{array}{l}\text { Age first had sexual } \\
\text { intercourse }\end{array}$ & $\begin{array}{r}-0.0481 \\
(0.0076)\end{array}$ & & & $\begin{array}{r}-0.0376 \\
(0.0080)\end{array}$ & $\begin{array}{l}-0.0203 \\
(0.0102)\end{array}$ \\
\hline $\begin{array}{l}\text { Has a savings account or } \\
\text { similar }\end{array}$ & & $\begin{array}{r}-0.0444 \\
(0.0338)\end{array}$ & & $\begin{array}{r}0.0138 \\
(0.0375)\end{array}$ & $\begin{array}{r}0.0080 \\
(0.0460)\end{array}$ \\
\hline $\begin{array}{l}\text { Fought at school or } \\
\text { work in past yr. }\end{array}$ & & & $\begin{array}{r}0.7211 \\
(0.0335)\end{array}$ & $\begin{array}{r}0.6865 \\
(0.0374)\end{array}$ & $\begin{array}{r}0.6172 \\
(0.0464)\end{array}$ \\
\hline $\begin{array}{l}\text { Has sex without birth } \\
\text { control }\end{array}$ & & & & & $\begin{array}{l}-0.0089 \\
(0.0549)\end{array}$ \\
\hline $\begin{array}{l}\text { Age started drinking >= } \\
\text { once per week }\end{array}$ & & & & & $\begin{array}{r}-0.0251 \\
(0.0104)\end{array}$ \\
\hline $\begin{array}{l}\text { Age first smoked } \\
\text { cigarette }\end{array}$ & & & & & $\begin{array}{r}-0.0178 \\
(0.0065)\end{array}$ \\
\hline $\begin{array}{l}\text { Attacked someone with } \\
\text { intent to injure in past } \\
\text { yr. } \\
\text { North (regional } \\
\text { dummy) }\end{array}$ & $\begin{array}{r}-0.0473 \\
(0.0511)\end{array}$ & $\begin{array}{r}-0.0570 \\
(0.0479)\end{array}$ & $\begin{array}{r}-0.0268 \\
(0.0475)\end{array}$ & $\begin{array}{r}-0.0407 \\
(0.0533)\end{array}$ & $\begin{array}{r}0.3767 \\
(0.0593) \\
-0.0039 \\
(0.0646)\end{array}$ \\
\hline $\begin{array}{l}\text { South (regional } \\
\text { dummy) }\end{array}$ & $\begin{array}{r}-0.2560 \\
(0.0494)\end{array}$ & $\begin{array}{r}-0.2469 \\
(0.0460)\end{array}$ & $\begin{array}{r}-0.2252 \\
(0.0459)\end{array}$ & $\begin{array}{r}-0.2635 \\
(0.0514)\end{array}$ & $\begin{array}{r}-0.2172 \\
(0.0631)\end{array}$ \\
\hline $\begin{array}{l}\text { Central (regional } \\
\text { dummy) }\end{array}$ & $\begin{array}{r}-0.0713 \\
(0.0494)\end{array}$ & $\begin{array}{r}-0.0824 \\
(0.0462)\end{array}$ & $\begin{array}{r}-0.0551 \\
(0.0460)\end{array}$ & $\begin{array}{r}-0.0649 \\
(0.0514)\end{array}$ & $\begin{array}{r}0.0103 \\
(0.0617)\end{array}$ \\
\hline $\operatorname{Ln}(L)$ & -4292 & -4908 & -4917 & .3954 & -2707 \\
\hline $1-\operatorname{Ln}\left(L / L_{0}\right)$ & .04 & .03 & .07 & .08 & .08 \\
\hline $\mathbf{N}$ & 7435 & 8703 & 9145 & 7143 & 4712 \\
\hline
\end{tabular}


Table 2G:

National Longitudinal Survey of Youth Data

Probits and OLS of Patience Measures

on Individual and Family Characteristics

\begin{tabular}{|c|c|c|c|c|c|}
\hline & $\begin{array}{r}(1) \\
\text { Has a } \\
\text { savings } \\
\text { account or } \\
\text { similar }\end{array}$ & $\begin{array}{r}\text { (2) } \\
\text { Age first } \\
\text { had sexual } \\
\text { ntercourse }\end{array}$ & $\begin{array}{r}\text { ( } 3) \\
\text { Has sox } \\
\text { without } \\
\text { birth } \\
\text { control }\end{array}$ & $\begin{array}{r}(4) \\
\text { Age started } \\
\text { drinklng >= } \\
\text { once per } \\
\text { wook }\end{array}$ & $\begin{array}{l}\text { ( 5) } \\
\text { Fought at } \\
\text { school or } \\
\text { work in } \\
\text { past yr. }\end{array}$ \\
\hline Intercept & $\begin{array}{r}2.7778 \\
(1.4748)\end{array}$ & $\begin{array}{r}17.2330 \\
(2 . \subseteq 896)\end{array}$ & $\begin{array}{r}-7.2060 \\
(1.7140)\end{array}$ & $\begin{array}{r}6.6822 \\
(2.3517)\end{array}$ & $\begin{array}{r}0.9877 \\
(1.4627)\end{array}$ \\
\hline SMSA & $\begin{array}{r}-0.0544 \\
(0.0495)\end{array}$ & $\begin{array}{r}-0.2369 \\
(0.0805)\end{array}$ & $\begin{array}{r}0.1333 \\
(0.0591)\end{array}$ & $\begin{array}{r}-0.0352 \\
(0.0802)\end{array}$ & $\begin{array}{r}0.0686 \\
(0.0493)\end{array}$ \\
\hline $\begin{array}{l}\text { SMSA at age } 14 \text {, but } \\
\text { non-SMSA now }\end{array}$ & $\begin{array}{r}-0.0990 \\
(0.0545)\end{array}$ & $\begin{array}{r}-0.1727 \\
(0.0891)\end{array}$ & $\begin{array}{r}0.0324 \\
(0.0658)\end{array}$ & $\begin{array}{r}-0.1607 \\
(0.0893)\end{array}$ & $\begin{array}{r}0.0558 \\
(0.0547)\end{array}$ \\
\hline $\begin{array}{l}\text { Changed city/town of } \\
\text { residence since birth }\end{array}$ & $\begin{array}{r}-0.0276 \\
(0.0311)\end{array}$ & $\begin{array}{r}-0.1386 \\
(0.0504)\end{array}$ & $\begin{array}{r}0.0112 \\
(0.0365)\end{array}$ & $\begin{array}{r}-0.1372 \\
(0.0494)\end{array}$ & $\begin{array}{r}0.0292 \\
(0.0310)\end{array}$ \\
\hline Age & $\begin{array}{r}-0.4139 \\
(0.1464)\end{array}$ & $\begin{array}{r}-0.3361 \\
(0.2344)\end{array}$ & $\begin{array}{r}0.5774 \\
(0.1688)\end{array}$ & $\begin{array}{r}0.7918 \\
(0.2313)\end{array}$ & $\begin{array}{r}-0.0529 \\
(0.1453)\end{array}$ \\
\hline Age squared & $\begin{array}{r}0.0088 \\
(0.0035)\end{array}$ & $\begin{array}{r}0.0078 \\
(0.0056)\end{array}$ & $\begin{array}{r}-0.0126 \\
(0.0040)\end{array}$ & $\begin{array}{r}-0.0162 \\
(0.0055)\end{array}$ & $\begin{array}{r}-0.0010 \\
(0.0035)\end{array}$ \\
\hline $\begin{array}{l}\text { Local unemployment } \\
\text { rate }\end{array}$ & $\begin{array}{r}-0.0602 \\
(0.0224)\end{array}$ & $\begin{array}{r}-0.0005 \\
(0.0364)\end{array}$ & $\begin{array}{r}0.0530 \\
(0.0264)\end{array}$ & $\begin{array}{r}-0.0109 \\
(0.0359)\end{array}$ & $\begin{array}{r}0.0164 \\
(0.0225)\end{array}$ \\
\hline $\begin{array}{l}\text { Family intact (mother } \\
\& \text { father) }\end{array}$ & $\begin{array}{r}0.2259 \\
(0.0332)\end{array}$ & $\begin{array}{r}0.4913 \\
(0.0545)\end{array}$ & $\begin{array}{r}-0.0696 \\
(0.0396)\end{array}$ & $\begin{array}{r}0.0620 \\
(0.0552)\end{array}$ & $\begin{array}{r}-0.0682 \\
(0.0336)\end{array}$ \\
\hline Highest grade achv'd & $\begin{array}{r}0.1428 \\
(0.0144)\end{array}$ & $\begin{array}{r}0.2862 \\
(0.0220)\end{array}$ & $\begin{array}{r}-0.0441 \\
(0.0157)\end{array}$ & $\begin{array}{r}0.1189 \\
(0.0231)\end{array}$ & $\begin{array}{r}.0 .0220 \\
(0.0143)\end{array}$ \\
\hline Male & $\begin{array}{r}-0.0636 \\
(0.0301)\end{array}$ & $\begin{array}{r}-1.3880 \\
(0.0485)\end{array}$ & $\begin{array}{r}0.4016 \\
(0.0355)\end{array}$ & $\begin{array}{r}-0.7056 \\
(0.0478)\end{array}$ & $\begin{array}{r}0.7946 \\
(0.0304)\end{array}$ \\
\hline Black & $\begin{array}{r}-0.4009 \\
(0.0415)\end{array}$ & $\begin{array}{r}-0.8923 \\
(0.0680)\end{array}$ & $\begin{array}{r}-0.0672 \\
(0.0498)\end{array}$ & $\begin{array}{r}0.4469 \\
(0.0701)\end{array}$ & $\begin{array}{r}0.1036 \\
(0.0417)\end{array}$ \\
\hline Hispanic & $\begin{array}{r}-0.0903 \\
(0.0482)\end{array}$ & $\begin{array}{r}0.4011 \\
(0.0810)\end{array}$ & $\begin{array}{r}-0.0142 \\
(0.0571)\end{array}$ & $\begin{array}{r}0.1887 \\
(0.0792)\end{array}$ & $\begin{array}{r}-0.0532 \\
(0.0490)\end{array}$ \\
\hline $\begin{array}{l}\text { Highest grade mother } \\
\text { achv'd }\end{array}$ & $\begin{array}{r}0.0358 \\
(0.0057)\end{array}$ & $\begin{array}{r}-0.0021 \\
(0.0094)\end{array}$ & $\begin{array}{r}-0.0096 \\
(0.0067)\end{array}$ & $\begin{array}{r}-0.0134 \\
(0.0093)\end{array}$ & $\begin{array}{r}0.0014 \\
(0.0057)\end{array}$ \\
\hline $\begin{array}{l}\text { Mother worked when } \\
\text { respondent was age } 14\end{array}$ & $\begin{array}{r}0.0782 \\
(0.0307)\end{array}$ & $\begin{array}{r}-0.0893 \\
(0.0492)\end{array}$ & $\begin{array}{r}0.0273 \\
(0.0358)\end{array}$ & $\begin{array}{r}-0.0264 \\
(0.0485)\end{array}$ & $\begin{array}{r}.0 .0244 \\
(0.0306)\end{array}$ \\
\hline AFQT Score & $\begin{array}{r}0.0137 \\
(0.0007)\end{array}$ & $\begin{array}{r}0.0089 \\
(0.0012)\end{array}$ & $\begin{array}{r}-0.0053 \\
(0.0008)\end{array}$ & $\begin{array}{r}0.0016 \\
(0.0011)\end{array}$ & $\begin{array}{r}-0.0075 \\
(0.0007)\end{array}$ \\
\hline $\begin{array}{l}\text { Altends church }>=\text { once } \\
\text { per month }\end{array}$ & $\begin{array}{r}0.1945 \\
(0.0313)\end{array}$ & $\begin{array}{r}0.6079 \\
(0.0498)\end{array}$ & $\begin{array}{r}-0.0473 \\
(0.0362)\end{array}$ & $\begin{array}{r}0.4432 \\
(0.0493)\end{array}$ & $\begin{array}{r}-0.0841 \\
(0.0311)\end{array}$ \\
\hline $\begin{array}{l}\text { North (regional } \\
\text { dummy) }\end{array}$ & $\begin{array}{r}0.0979 \\
(0.0505)\end{array}$ & $\begin{array}{r}0.1174 \\
(0.0802)\end{array}$ & $\begin{array}{r}0.0285 \\
(0.0581)\end{array}$ & $\begin{array}{r}-0.1714 \\
(0.0783)\end{array}$ & $\begin{array}{r}-0.1005 \\
(0.0499)\end{array}$ \\
\hline $\begin{array}{l}\text { South (regional } \\
\text { dummy) }\end{array}$ & $\begin{array}{r}-0.0155 \\
(0.0471)\end{array}$ & $\begin{array}{r}0.0194 \\
(0.0765)\end{array}$ & $\begin{array}{r}0.0029 \\
(0.0559)\end{array}$ & $\begin{array}{r}-0.0491 \\
(0.0757)\end{array}$ & $\begin{array}{r}-0.0476 \\
(0.0473)\end{array}$ \\
\hline $\begin{array}{l}\text { Central (regional } \\
\text { dummy) }\end{array}$ & $\begin{array}{r}-0.0140 \\
(0.0484)\end{array}$ & $\begin{array}{r}0.1486 \\
(0.0773)\end{array}$ & $\begin{array}{r}0.0748 \\
(0.0564)\end{array}$ & $\begin{array}{r}-0.0164 \\
(0.0756)\end{array}$ & $\begin{array}{r}-0.0535 \\
(0.0483)\end{array}$ \\
\hline $\operatorname{Ln}$ (L) & -4707 & & -3236 & & -4700 \\
\hline $\begin{array}{l}1-\operatorname{Ln}\left(L / L_{0}\right) \\
\text { or } R^{2}\end{array}$ & .18 & .27 & .04 & .11 & .13 \\
\hline $\mathbf{N}$ & 8703 & 7435 & 8484 & 7019 & 9145 \\
\hline
\end{tabular}


Table 3A:

Cross City Data

Uniform Crime Reports and Count and City Databook Means and Standard Deviations

\begin{tabular}{|c|c|}
\hline$\overline{\mathrm{N}}=633$ & Mean and S.D. \\
\hline Serious Crimes per Capita (unadjusted) & $\begin{array}{r}.0776 \\
(.0289)\end{array}$ \\
\hline $\begin{array}{l}\text { Serious Crimes per Capita (adjusted for } \\
\text { reporting bias) }\end{array}$ & $\begin{array}{r}.1651 \\
(.0672)\end{array}$ \\
\hline Value taken per crime & $\begin{array}{r}\$ 543 \\
(\$ 304)\end{array}$ \\
\hline Arrests per crime & $\begin{array}{r}.2413 \\
(.0845)\end{array}$ \\
\hline North (regional dummy) & $\begin{array}{r}.2003 \\
(.4006)\end{array}$ \\
\hline South (regional dummy) & $\begin{array}{r}.2760 \\
(.4474)\end{array}$ \\
\hline Central (regional dummy) & $\begin{array}{r}.2729 \\
(.4458)\end{array}$ \\
\hline Population 1982 & $\begin{array}{r}116,852 \\
(334,666)\end{array}$ \\
\hline Percent pop. below poverty 1979 & $\begin{array}{l}.1226 \\
(.0596)\end{array}$ \\
\hline Percent housing owner occupied & $\begin{array}{l}.5744 \\
(.1241)\end{array}$ \\
\hline Percent non-white & $\begin{array}{l}.1831 \\
(.1659)\end{array}$ \\
\hline Percent with 4 yrs high school & $\begin{array}{r}.6860 \\
(.1126)\end{array}$ \\
\hline Percent with 4 yrs college & $\begin{array}{r}.1799 \\
(.0953)\end{array}$ \\
\hline Unemployment rate & $\begin{array}{r}.0697 \\
(.0308)\end{array}$ \\
\hline Percent female head of household & $\begin{array}{l}.1723 \\
(.0587)\end{array}$ \\
\hline Police per capita & $\begin{array}{r}.0018 \\
(.0006)\end{array}$ \\
\hline
\end{tabular}

source: County and City Databook, FBI Uniform Crime Reports 
Table 3B:

Cross City Data.- Regressions of Crime Rate on City Size and Other City Characteristics

\begin{tabular}{|c|c|c|c|c|c|c|c|}
\hline dependent variable & $\begin{array}{r}(1) \\
\text { log ser. } \\
\text { crimes } \\
\text { capita } \\
-4.409 \\
(.1981)\end{array}$ & $\begin{array}{r}(2) \\
\text { log ser. } \\
\text { crimes } \\
\text { capita } \\
-3.738 \\
(.2824)\end{array}$ & $\begin{array}{r}(3) \\
\text { log ser. } \\
\text { crimes } \\
\text { capita } \\
-4.223 \\
(.2853)\end{array}$ & $\begin{array}{r}\text { (4) } \\
\text { log ser. } \\
\text { crimes } \\
\text { adjustd } \\
-4.389 \\
(.2924)\end{array}$ & $\begin{array}{r}\text { (5) } \\
\text { log } \\
\text { assaults } \\
\text { capita } \\
-6.973 \\
(.5639)\end{array}$ & $\begin{array}{r}(6) \\
\text { log } \\
\text { rapes } \\
\text { capita } \\
-12.48 \\
(.5448)\end{array}$ & $\begin{array}{r}(7) \\
\text { log ser. } \\
\text { crimes } \\
\text { adjustd } \\
-4.5000 \\
(.2019)\end{array}$ \\
\hline $\begin{array}{l}\text { Log (City Population } \\
1982 \text { ) }\end{array}$ & $\begin{array}{r}.1635 \\
(.0173)\end{array}$ & $\begin{array}{l}.1016 \\
(.0163)\end{array}$ & $\begin{array}{r}.0933 \\
(.0159)\end{array}$ & $\begin{array}{l}.1689 \\
(.0164)\end{array}$ & $\begin{array}{r}.0947 \\
(.0315)\end{array}$ & $\begin{array}{r}.2051 \\
(.0304)\end{array}$ & $\begin{array}{r}.2382 \\
(.0177)\end{array}$ \\
\hline $\begin{array}{l}\text { Percent pop. below } \\
\text { poverty } 1979\end{array}$ & & $\begin{array}{r}1.863 \\
(.4224)\end{array}$ & $\begin{array}{r}.6145 \\
(.4574)\end{array}$ & $\begin{array}{r}.5246 \\
(.4701)\end{array}$ & $\begin{array}{r}.3487 \\
(.9039)\end{array}$ & $\begin{array}{r}1.551 \\
(.8726)\end{array}$ & \\
\hline $\begin{array}{l}\text { Percent housing owner } \\
\text { occupied }\end{array}$ & & $\begin{array}{r}-.4139 \\
(.1492)\end{array}$ & $\begin{array}{r}-.1241 \\
(.1524)\end{array}$ & $\begin{array}{l}-.1164 \\
(.1566)\end{array}$ & $\begin{array}{r}-.0352 \\
(.3011)\end{array}$ & $\begin{array}{r}-.2643 \\
(.3067)\end{array}$ & \\
\hline Percent non-white & & $\begin{array}{r}.3224 \\
(.1102)\end{array}$ & $\begin{array}{r}-.2903 \\
(.1460)\end{array}$ & $\begin{array}{l}-.3072 \\
(.1501)\end{array}$ & $\begin{array}{r}-.1625 \\
(.2884)\end{array}$ & $\begin{array}{r}-.2356 \\
(.2797)\end{array}$ & \\
\hline $\begin{array}{l}\text { Percent with } 4 \text { yrs high } \\
\text { school }\end{array}$ & & $\begin{array}{r}.1523 \\
(.2737)\end{array}$ & $\begin{array}{r}.2288 \\
(.2661)\end{array}$ & $\begin{array}{r}.3006 \\
(.2744)\end{array}$ & $\begin{array}{l}.1232 \\
(.5260)\end{array}$ & $\begin{array}{r}2.072 \\
(.5198)\end{array}$ & \\
\hline $\begin{array}{l}\text { Percent with } 4 \text { yrs } \\
\text { college }\end{array}$ & & $\begin{array}{r}-.6324 \\
(.2564)\end{array}$ & $\begin{array}{r}-.4055 \\
(.2518)\end{array}$ & $\begin{array}{r}-.4343 \\
(.2592)\end{array}$ & $\begin{array}{r}-.5068 \\
(.4975)\end{array}$ & $\begin{array}{r}-2.192 \\
(.5125)\end{array}$ & \\
\hline Unemployment rate & & $\begin{array}{l}.2710 \\
(.5937)\end{array}$ & $\begin{array}{r}.9305 \\
(.5865)\end{array}$ & $\begin{array}{r}1.016 \\
(.6032)\end{array}$ & $\begin{array}{r}3.271 \\
(1.159)\end{array}$ & $\begin{array}{r}1.283 \\
(1.115)\end{array}$ & \\
\hline $\begin{array}{l}\text { Percent female head of } \\
\text { household }\end{array}$ & & & $\begin{array}{r}3.367 \\
(.5451)\end{array}$ & $\begin{array}{r}3.491 \\
(.5608)\end{array}$ & $\begin{array}{r}4.925 \\
(1.077)\end{array}$ & $\begin{array}{r}6.96 \\
(1.035)\end{array}$ & \\
\hline $\begin{array}{l}\text { North (regional } \\
\text { dummy) }\end{array}$ & $\begin{array}{l}-.1814 \\
(.0438)\end{array}$ & $\begin{array}{l}-.2602 \\
(.0473)\end{array}$ & $\begin{array}{l}-.3696 \\
(.0493)\end{array}$ & $\begin{array}{l}-.3696 \\
(.0507)\end{array}$ & $\begin{array}{r}-.2249 \\
(.0974)\end{array}$ & $\begin{array}{r}-.4476 \\
(.0965)\end{array}$ & $\begin{array}{r}-.1863 \\
(.0446)\end{array}$ \\
\hline $\begin{array}{l}\text { South (regional } \\
\text { dummy) }\end{array}$ & $\begin{array}{r}.0877 \\
(.0399)\end{array}$ & $\begin{array}{r}-.0374 \\
(.0434)\end{array}$ & $\begin{array}{r}-.0359 \\
(.0421)\end{array}$ & $\begin{array}{r}-.0195 \\
(.0433)\end{array}$ & $\begin{array}{r}.0489 \\
(.0832)\end{array}$ & $\begin{array}{r}.1124 \\
(.0808)\end{array}$ & $\begin{array}{r}.0957 \\
(.0407)\end{array}$ \\
\hline $\begin{array}{l}\text { Central (regional } \\
\text { dummy) }\end{array}$ & $\begin{array}{l}-.1091 \\
(.0405)\end{array}$ & $\begin{array}{r}-.0761 \\
(.0397)\end{array}$ & $\begin{array}{r}-.1566 \\
(.0407)\end{array}$ & $\begin{array}{l}-.1586 \\
(.0419)\end{array}$ & $\begin{array}{r}-.0381 \\
(.0804)\end{array}$ & $\begin{array}{r}-.0709 \\
(.0777)\end{array}$ & $\begin{array}{r}-.1105 \\
(.0413)\end{array}$ \\
\hline $\mathbf{N}$ & 633 & 633 & 633 & 633 & 633 & 633 & 633 \\
\hline $\mathbf{R}^{2}$ & .20 & .38 & .42 & .48 & 28 & .44 & .29 \\
\hline
\end{tabular}

Standard deviations shown in parentheses.

Adjusted crime numbers are adjusted by city size for under-reporting of crimes. Adjustment methodology uses crime and reporting data from National Survey of Crime Victimization. 
Table 3C:

Cross City Data-- Regressions of Value Taken, Arrest Rate, Crime Rate on City Size and Other City Characteristics

\begin{tabular}{|c|c|c|c|c|c|}
\hline dependent variable & $\begin{array}{r}\text { (1) } \\
\text { log } \\
\text { Value } \\
\text { per } \\
\text { Crime } \\
4.985 \\
(.5566)\end{array}$ & $\begin{array}{r}\text { (2) } \\
\text { log } \\
\text { Arrests } \\
\text { per } \\
\text { Crime } \\
-1.181 \\
(.3875)\end{array}$ & $\begin{array}{r}\text { log } \\
\text { log } \\
\text { Adjustd } \\
\text { Arrests } \\
\text { per } \\
\text { Crime } \\
-1.000 \\
(.3902)\end{array}$ & $\begin{array}{r}(4) \\
\text { log } \\
\text { Police } \\
\text { Officers } \\
\text { Capita } \\
-7.102 \\
(.1907)\end{array}$ & $\begin{array}{r}\text { (5) } \\
\text { log } \\
\text { Ser. } \\
\text { Crimes } \\
\text { Capita } \\
-3.371 \\
(.3179)\end{array}$ \\
\hline $\begin{array}{l}\text { Serious Crimes per } \\
\text { Capita }\end{array}$ & $\begin{array}{r}-.3693 \\
(.0672)\end{array}$ & - & - & - & \\
\hline $\begin{array}{l}\text { Log (City Population } \\
1982 \text { ) }\end{array}$ & $\begin{array}{r}.1471 \\
(.0275)\end{array}$ & $\begin{array}{r}-.0221 \\
(.0216)\end{array}$ & $\begin{array}{r}-.0981 \\
(.0217)\end{array}$ & $\begin{array}{r}.0468 \\
(.0106)\end{array}$ & $\begin{array}{l}.1081 \\
(.0158)\end{array}$ \\
\hline $\begin{array}{l}\text { Percent pop. below } \\
\text { poverty } 1979\end{array}$ & $\begin{array}{r}-3.392 \\
(.7684)\end{array}$ & $\begin{array}{r}1.018 \\
(.6211)\end{array}$ & $\begin{array}{r}1.107 \\
(.6236)\end{array}$ & $\begin{array}{r}-1.820 \\
(.3056)\end{array}$ & $\begin{array}{r}.1323 \\
(.4554)\end{array}$ \\
\hline $\begin{array}{l}\text { Percent housing owner } \\
\text { occupied }\end{array}$ & $\begin{array}{r}-.7047 \\
(.2558)\end{array}$ & $\begin{array}{l}.1014 \\
(.2069)\end{array}$ & $\begin{array}{r}.0952 \\
(.2078)\end{array}$ & $\begin{array}{r}-.0767 \\
(.1018)\end{array}$ & $\begin{aligned}-.2094 \\
(.1497)\end{aligned}$ \\
\hline Percent non-white & $\begin{array}{r}.8068 \\
(.2456)\end{array}$ & $\begin{array}{l}.0102 \\
(.1982)\end{array}$ & $\begin{array}{r}.0307 \\
(.1991)\end{array}$ & $\begin{array}{r}-.2592 \\
(.0975)\end{array}$ & $\begin{array}{r}-.1766 \\
(.1441)\end{array}$ \\
\hline $\begin{array}{l}\text { Percent with } 4 \text { yrs high } \\
\text { school }\end{array}$ & $\begin{array}{r}-.3918 \\
(.4468)\end{array}$ & $\begin{array}{l}.1515 \\
(.3615)\end{array}$ & $\begin{array}{l}.0656 \\
(.3640)\end{array}$ & $\begin{array}{r}-.7107 \\
(.1778)\end{array}$ & $\begin{array}{l}.1648 \\
(.2603)\end{array}$ \\
\hline $\begin{array}{l}\text { Percent with } 4 \text { yrs } \\
\text { college }\end{array}$ & $\begin{array}{r}-.3170 \\
(.4232)\end{array}$ & $\begin{array}{r}-.3873 \\
(.3419)\end{array}$ & $\begin{array}{r}-.3493 \\
(.3437)\end{array}$ & $\begin{array}{r}.8100 \\
(.1682)\end{array}$ & $\begin{array}{r}-.4147 \\
(.2463)\end{array}$ \\
\hline Unemployment rate & $\begin{array}{r}-1.659 \\
(.9859)\end{array}$ & $\begin{array}{r}-1.142 \\
(.7965)\end{array}$ & $\begin{array}{r}-1.239 \\
(.8000)\end{array}$ & $\begin{array}{r}.3383 \\
(.3920)\end{array}$ & $\begin{array}{r}.7148 \\
(.5760)\end{array}$ \\
\hline $\begin{array}{l}\text { Percent female head of } \\
\text { household }\end{array}$ & $\begin{array}{r}-1.006 \\
(.9420)\end{array}$ & $\begin{array}{r}-1.011 \\
(.7402)\end{array}$ & $\begin{array}{r}-1.151 \\
(.7438)\end{array}$ & $\begin{array}{r}4.102 \\
(.3642)\end{array}$ & $\begin{array}{r}3.117 \\
(.5360)\end{array}$ \\
\hline Log (Value/ Crime) & & & & & $\begin{array}{l}-.1248 \\
(.0228)\end{array}$ \\
\hline Log (Arrests/ Crime) & & & & & $\begin{array}{r}.0300 \\
(.0289)\end{array}$ \\
\hline $\begin{array}{l}\text { North (regional } \\
\text { dummy) }\end{array}$ & $\begin{array}{r}-.0975 \\
(.0863)\end{array}$ & $\begin{array}{l}-.0862 \\
(.0669)\end{array}$ & $\begin{array}{r}-.0867 \\
(.0672)\end{array}$ & $\begin{array}{r}.2727 \\
(.0329)\end{array}$ & $\begin{array}{r}-.3621 \\
(.0482)\end{array}$ \\
\hline $\begin{array}{l}\text { South (regional } \\
\text { dummy) }\end{array}$ & $\begin{array}{l}.0129 \\
(.0707)\end{array}$ & $\begin{array}{r}.0470 \\
(.0572)\end{array}$ & $\begin{array}{r}.0295 \\
(.0575)\end{array}$ & $\begin{array}{l}.2099 \\
(.0282)\end{array}$ & $\begin{array}{l}-.0341 \\
(.0412)\end{array}$ \\
\hline $\begin{array}{l}\text { Central (regional } \\
\text { dummy) }\end{array}$ & $\begin{array}{r}-.5857 \\
(.0691)\end{array}$ & $\begin{array}{r}-.0960 \\
(.0553)\end{array}$ & $\begin{array}{l}-.0932 \\
(.0555)\end{array}$ & $\begin{array}{l}.1031 \\
(.0272)\end{array}$ & $\begin{array}{l}-.2196 \\
(.0417)\end{array}$ \\
\hline $\mathbf{N}$ & 633 & 633 & 633 & 633 & 633 \\
\hline $\mathbf{R}^{2}$ & .31 & .04 & .07 & .58 & .45 \\
\hline
\end{tabular}

Standard deviations shown in parentheses. Adjusted crime numbers are adjusted by city size for under-reporting of crimes. 
Table 3D:

Cross City Data-- Regressions of Crime Rate on City Size and Other City Characteristics with Elasticities of Crime with Respect to Arrest Rate and Value Per Crime Fixed

\begin{tabular}{|c|c|c|c|c|c|}
\hline dependent variable & $\begin{array}{r}(1) \\
\text { Log } \\
\text { Serious } \\
\text { Crimes } \\
\text { Capita } \\
-5.7689 \\
(0.3338)\end{array}$ & $\begin{array}{r}(2) \\
\text { Log } \\
\text { Serious } \\
\text { Crimes } \\
\text { Capita } \\
-6.4233 \\
(0.3600)\end{array}$ & $\begin{array}{r}(3) \\
\text { Log } \\
\text { Serious } \\
\text { Crimes } \\
\text { Capita } \\
-8.6231 \\
(0.4838)\end{array}$ & $\begin{array}{r}(4) \\
\text { Log } \\
\text { Serious } \\
\text { Crimes } \\
\text { Adj'd } \\
-5.9258 \\
(0.3409)\end{array}$ & $\begin{array}{r}(5) \\
\text { Log } \\
\text { Serious } \\
\text { Crimes } \\
\text { Adj'd } \\
-6.5940 \\
(0.3670)\end{array}$ \\
\hline $\begin{array}{l}\text { Log (City Population } \\
1982 \text { ) }\end{array}$ & $\begin{array}{r}0.0664 \\
(0.0186)\end{array}$ & $\begin{array}{r}0.0551 \\
(0.0201)\end{array}$ & $\begin{array}{r}0.0169 \\
(0.0270)\end{array}$ & $\begin{array}{r}0.1275 \\
(0.0190)\end{array}$ & $\begin{array}{r}0.1166 \\
(0.0204)\end{array}$ \\
\hline $\begin{array}{l}\text { Percent pop. below } \\
\text { poverty } 1979\end{array}$ & $\begin{array}{r}1.5420 \\
(0.5351)\end{array}$ & $\begin{array}{r}1.9039 \\
(0.5771)\end{array}$ & $\begin{array}{r}3.1933 \\
(0.7755)\end{array}$ & $\begin{array}{r}1.4713 \\
(0.5449)\end{array}$ & $\begin{array}{r}1.8340 \\
(0.5865)\end{array}$ \\
\hline $\begin{array}{l}\text { Percent housing owner } \\
\text { occupied }\end{array}$ & $\begin{array}{r}0.0279 \\
(0.1783)\end{array}$ & $\begin{array}{r}0.0938 \\
(0.1922)\end{array}$ & $\begin{array}{r}0.3117 \\
(0.2583)\end{array}$ & $\begin{array}{r}0.0317 \\
(0.1815)\end{array}$ & $\begin{array}{r}0.0962 \\
(0.1954)\end{array}$ \\
\hline Percent non-white & $\begin{array}{r}-0.4711 \\
(0.1707)\end{array}$ & $\begin{array}{r}-0.5625 \\
(0.1842)\end{array}$ & $\begin{array}{r}-0.8347 \\
(0.2475)\end{array}$ & $\begin{array}{r}-0.4904 \\
(0.1740)\end{array}$ & $\begin{array}{r}-0.5850 \\
(0.1873)\end{array}$ \\
\hline $\begin{array}{l}\text { Percent with } 4 \text { yrs high } \\
\text { school }\end{array}$ & $\begin{array}{r}0.3544 \\
(0.3114)\end{array}$ & $\begin{array}{r}0.4020 \\
(0.3358)\end{array}$ & $\begin{array}{r}0.5752 \\
(0.4513)\end{array}$ & $\begin{array}{r}0.4342 \\
(0.3180)\end{array}$ & $\begin{array}{r}0.4944 \\
(0.3423)\end{array}$ \\
\hline $\begin{array}{l}\text { Percent with } 4 \text { yrs } \\
\text { college }\end{array}$ & $\begin{array}{r}-0.4495 \\
(0.2945)\end{array}$ & $\begin{array}{r}-0.4328 \\
(0.3177)\end{array}$ & $\begin{array}{r}-0.4600 \\
(0.4269)\end{array}$ & $\begin{array}{r}-0.4870 \\
(0.3003)\end{array}$ & $\begin{array}{r}-0.4785 \\
(0.3233)\end{array}$ \\
\hline Unemployment rate & $\begin{array}{r}1.1028 \\
(0.6861)\end{array}$ & $\begin{array}{r}1.3031 \\
(0.7400)\end{array}$ & $\begin{array}{r}1.6757 \\
(0.9944)\end{array}$ & $\begin{array}{r}1.1899 \\
(0.6990)\end{array}$ & $\begin{array}{r}1.4008 \\
(0.7523)\end{array}$ \\
\hline $\begin{array}{l}\text { Percent female head of } \\
\text { household }\end{array}$ & $\begin{array}{r}3.6150 \\
(0.6376)\end{array}$ & $\begin{array}{r}3.8399 \\
(0.6877)\end{array}$ & $\begin{array}{r}4.3125 \\
(0.9241)\end{array}$ & $\begin{array}{r}3.7390 \\
(0.6499)\end{array}$ & $\begin{array}{r}3.9781 \\
(0.6995)\end{array}$ \\
\hline Log (Value/ Crime) & $\begin{array}{l}0.2000 \\
\text { (fixed) }\end{array}$ & $\begin{array}{l}0.3000 \\
\text { (fixed) }\end{array}$ & $\begin{array}{l}0.6000 \\
\text { (fixed) }\end{array}$ & $\begin{array}{r}0.2000 \\
\text { (fixed) }\end{array}$ & $\begin{array}{r}0.3000 \\
\text { (fixed) }\end{array}$ \\
\hline Log (Arrests/ Crime) & $\begin{array}{r}-0.2000 \\
\text { (fixed) }\end{array}$ & $\begin{array}{r}-0.2000 \\
\text { (fixed) }\end{array}$ & $\begin{array}{r}-0.4000 \\
(\text { fixed) }\end{array}$ & $\begin{array}{r}-0.2000 \\
(\text { fixed) }\end{array}$ & $\begin{array}{r}-0.2000 \\
\text { (fixed) }\end{array}$ \\
\hline $\begin{array}{l}\text { North (regional } \\
\text { dummy) }\end{array}$ & $\begin{array}{r}-0.3946 \\
(0.0576)\end{array}$ & $\begin{array}{r}-0.3985 \\
(0.0622)\end{array}$ & $\begin{array}{r}-0.4275 \\
(0.0835)\end{array}$ & $\begin{array}{r}-0.3936 \\
(0.0587)\end{array}$ & $\begin{array}{r}-0.3969 \\
(0.0632)\end{array}$ \\
\hline $\begin{array}{l}\text { South (regional } \\
\text { dummy) }\end{array}$ & $\begin{array}{r}-0.0317 \\
(0.0493)\end{array}$ & $\begin{array}{r}-0.0344 \\
(0.0532)\end{array}$ & $\begin{array}{r}-0.0328 \\
(0.0714)\end{array}$ & $\begin{array}{r}-0.0169 \\
(0.0502)\end{array}$ & $\begin{array}{r}-0.0186 \\
(0.0541)\end{array}$ \\
\hline $\begin{array}{l}\text { Central (regional } \\
\text { dummy) }\end{array}$ & $\begin{array}{r}-0.0702 \\
(0.0476)\end{array}$ & $\begin{array}{r}-0.0175 \\
(0.0514)\end{array}$ & $\begin{array}{r}0.1217 \\
(0.0690)\end{array}$ & $\begin{array}{r}-0.0731 \\
(0.0485)\end{array}$ & $\begin{array}{r}-0.0210 \\
(0.0522)\end{array}$ \\
\hline $\mathbf{N}$ & 633 & 633 & 633 & 633 & 633 \\
\hline
\end{tabular}

Standard deviations shown in parentheses. Adjusted crime numbers are adjusted by city size for under-reporting of crimes. Regressions w/ adjusted crime rate use adjusted arrest rate. 
Basic Decomposition:

$\varepsilon_{\mathrm{N}}^{\mathrm{Q}}=\varepsilon_{\mathrm{P}}^{\mathrm{Q}} \varepsilon_{\mathrm{N}}^{\mathrm{P}}+\frac{\mathrm{KS}}{\mathrm{PC}} \varepsilon_{\mathrm{P}}^{\mathrm{Q}} \varepsilon_{\mathrm{N}}^{\mathrm{K}}-\frac{\mathrm{B}}{\mathrm{PC}} \varepsilon_{\mathrm{P}}^{\mathrm{Q}} \varepsilon_{\mathrm{N}}^{\mathrm{B}}+\mathrm{NZ}^{\prime}(\mathrm{N}) \frac{\theta_{\mathrm{Z}}+\mathrm{PC}_{\mathrm{Z}}}{\mathrm{QB}_{\mathrm{Q}}}+\mathrm{N} \frac{\mathrm{dX}}{\mathrm{dN}} \frac{\theta_{\mathrm{X}}+\mathrm{PC}_{\mathrm{X}}}{\mathrm{QB}_{\mathrm{Q}}}$

Raw Elasticity (Including Regional Dummies): $\varepsilon_{N}^{Q}=0.1635$.

Controlling for Variables: $N Z^{\prime}(N) \frac{\theta_{Z}+P C_{Z}}{Q B_{Q}}+N \frac{d X}{d N} \frac{\theta_{X}+P C_{X}}{Q B_{Q}}$

Purely Exogenous Variables, with no other controls: $N \frac{d X}{d N} \frac{\theta_{X}+P C_{X}}{Q B_{Q}}>.05$.

Combined Exogenous and Endogenous Variables

Female Headed Household: .074

All Other Variables: -.0038.

The Benefits of Crime $-\frac{B}{P C} \varepsilon_{P}^{Q} \varepsilon_{N}^{B}$

The elasticity of benefits with respect to city size $\varepsilon_{N}^{B}=.1471$

Possible ratios of benefits to costs: $\frac{B}{P C}=1-2$

Possible elasticities of crime with respect to the probability of arrest: $\varepsilon_{P}^{Q}=.1-.4$

Range of the Effects of Benefits:

Best Point Estimate of Benefits Effect $-\varepsilon_{P}^{Q} \varepsilon_{N}^{B} B / P C=.0147 \rightarrow .1177$ $-\varepsilon_{P}^{Q} \varepsilon_{N}^{B} B / P C=.044$ 


\section{Table 4, Continued}

\section{The Probability of Arrest $\varepsilon_{P}^{Q} \varepsilon_{N}^{P}$}

The elasticity of arrest probability with respect to city $\operatorname{size} \varepsilon_{N}^{B}=-.0221$, using arrests per reported crime.

The elasticity of arrest probability with respect to city $\operatorname{size} \varepsilon_{N}^{B}=-.0981$, using arrests per true crime.

Possible elasticities of crime with respect to the probability of arrest: $\varepsilon_{P}^{Q}=.1-.4$

For Arrests per Reported Crime:

Range of the Effects of Arrests:

Best Point Estimate of Arrests Effect

$\varepsilon_{P}^{Q} \varepsilon_{N}^{P}=.0022 \rightarrow .0088$

$$
\varepsilon_{P}^{Q} \varepsilon_{N}^{P}=.0044
$$

For Arrests per True Crime:

Range of the Effects of Arrests: Best Point Estimate of Arrests Effect $\varepsilon_{P}^{Q} \varepsilon_{N}^{P}=.0098 \rightarrow .0392$ $\varepsilon_{P}^{Q} \varepsilon_{N}^{P}=.0196$

The Effect of Knowing One's Attacker: $\frac{K S}{P C} \varepsilon_{P}^{Q} \varepsilon_{N}^{K}$

Range of KS/PC: .25-.5.

Possible elasticities of crime with recpect to the probability of arrest: $\varepsilon_{P}^{Q}=.1-.4$ Elasticity of Knowing Your Attacker with Respect to City Size: $\varepsilon_{N}^{K}=-.107$

Range of the Effects of Knowing: Best Point Estimate of Arrests Effect $\varepsilon_{P}^{Q} \varepsilon_{N}^{P}=.0027 \rightarrow .0214 \quad \mathcal{E}_{P}^{Q} \varepsilon_{N}^{P}=.0054$

\section{Final Total}

.1635 Base Elasticity

- $\quad .074 \quad$ Female Headed Households Effect

$+\quad .004$ Other Observable Variables

- $\quad .044 \quad$ Higher Returns to Crime

- $\quad .020$ Lower Probability of Arrest

- $\quad .005$ Lower Probability of Recognition

.024 Remainng Urban Crime Effect 
Figure 1: Crime and City Population

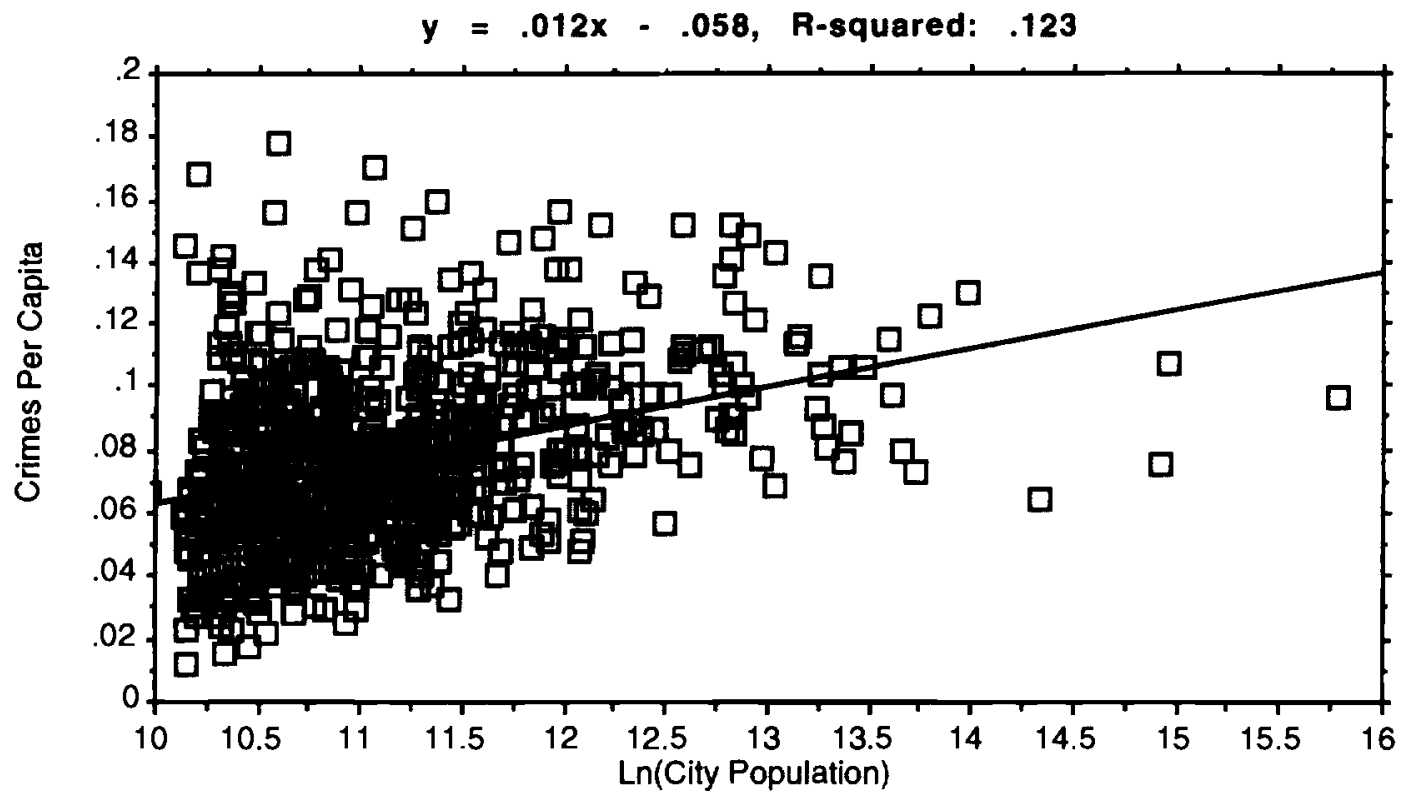

Figure 2: Murder and City Population

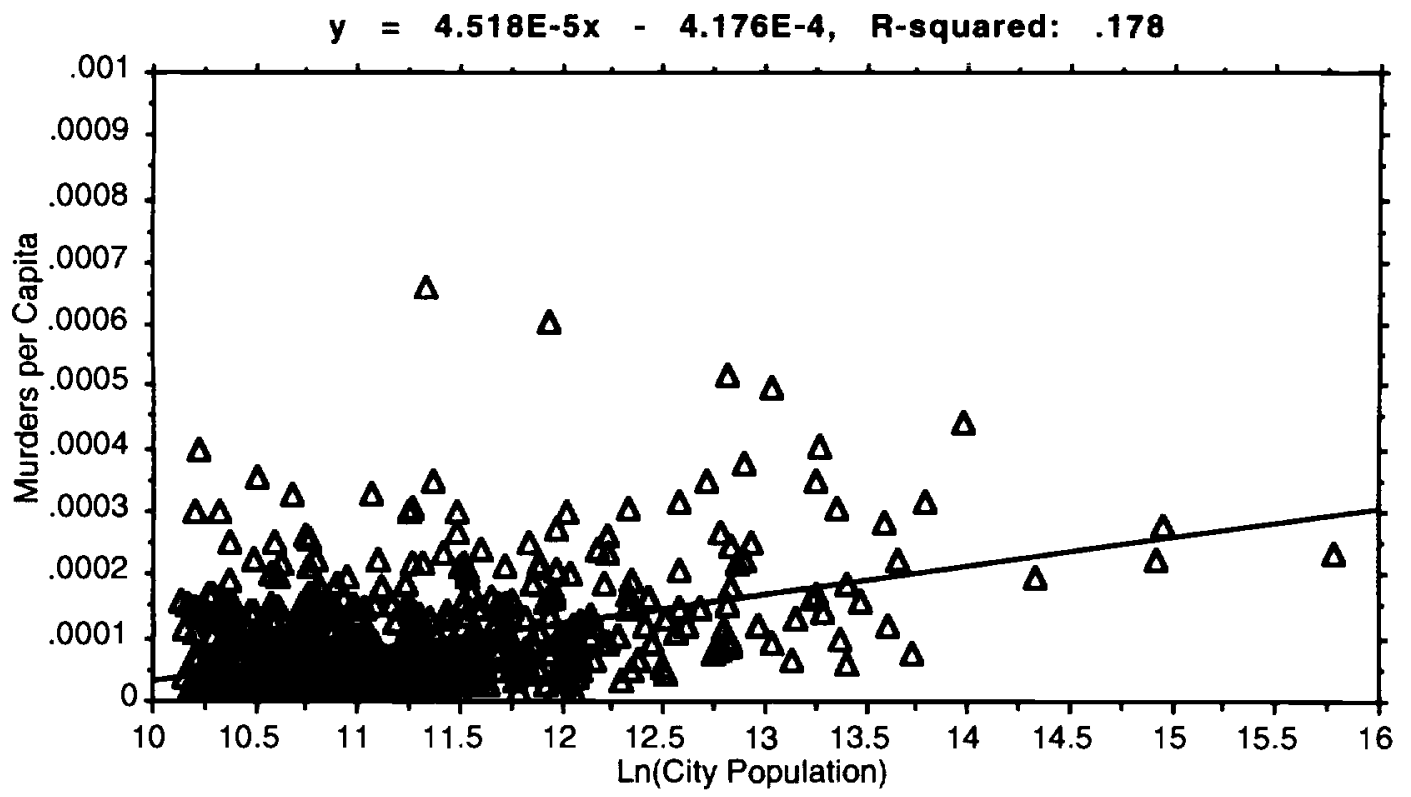

These figure shows the relationship between crime and city population taken from the 1982 Uniform Crime Reports, and the 1980 census. The t-statistic in the first regression is 9.44; the t-statistic in the second regression is 11.27 . 


\section{Figure 3}

\section{Crimes / Capita}

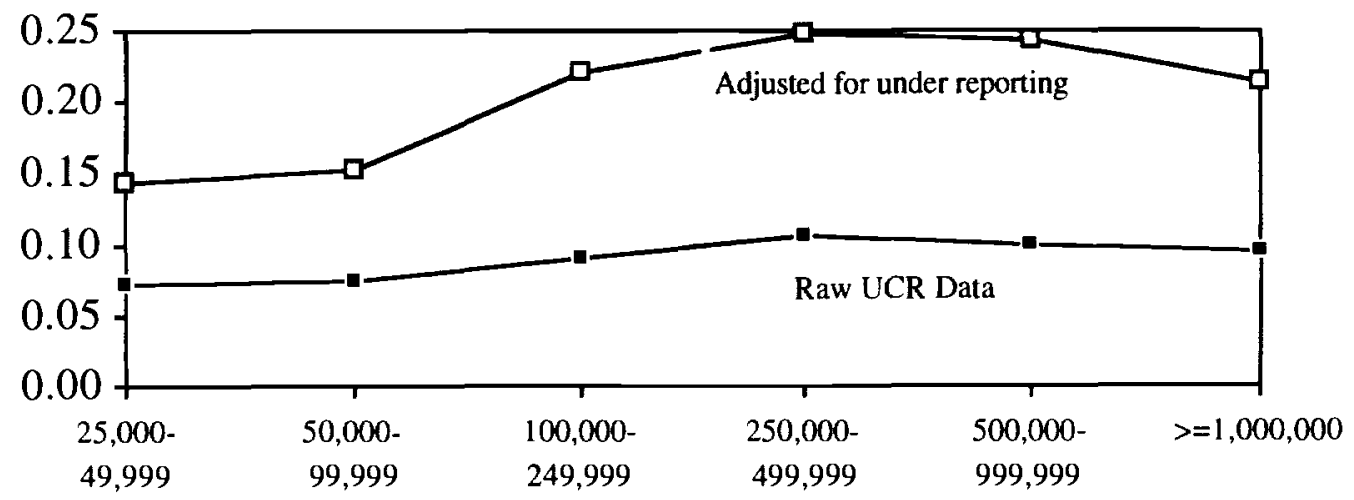

City Population

Arrests /Crime

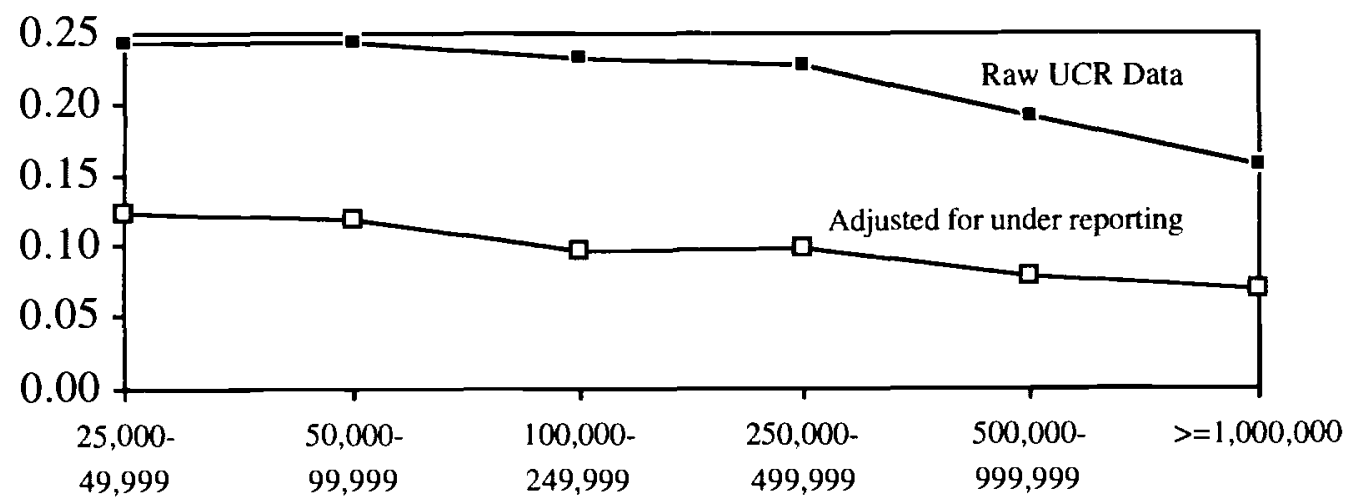

City Population

Value/ Crime (UCR)

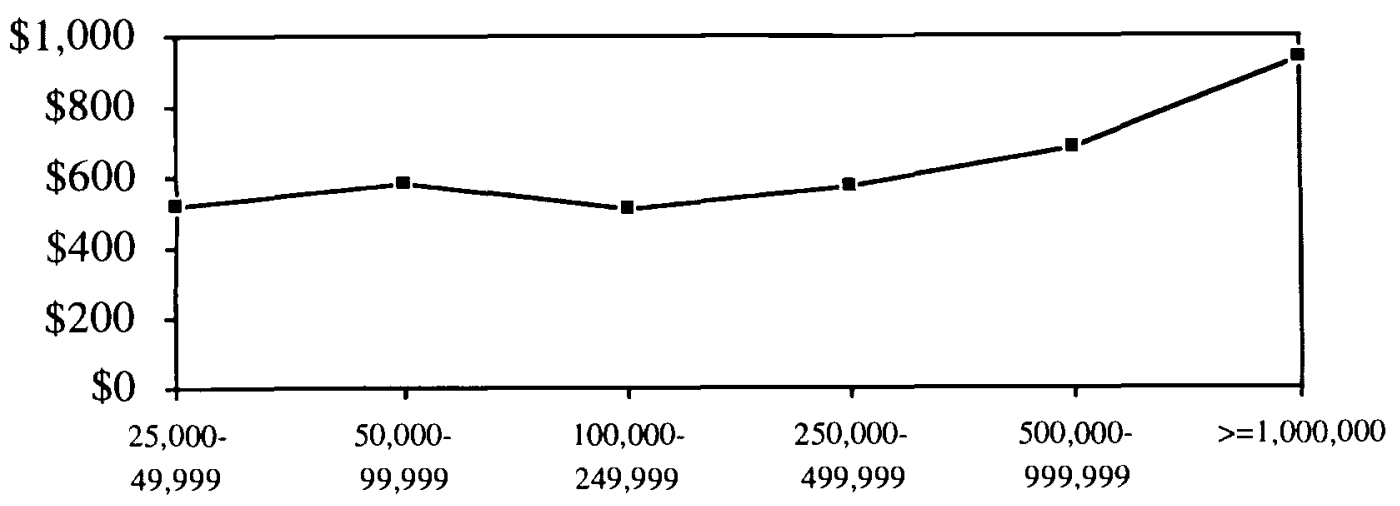

City Population 


\section{Figure 4}

\section{Crimes / Capita}

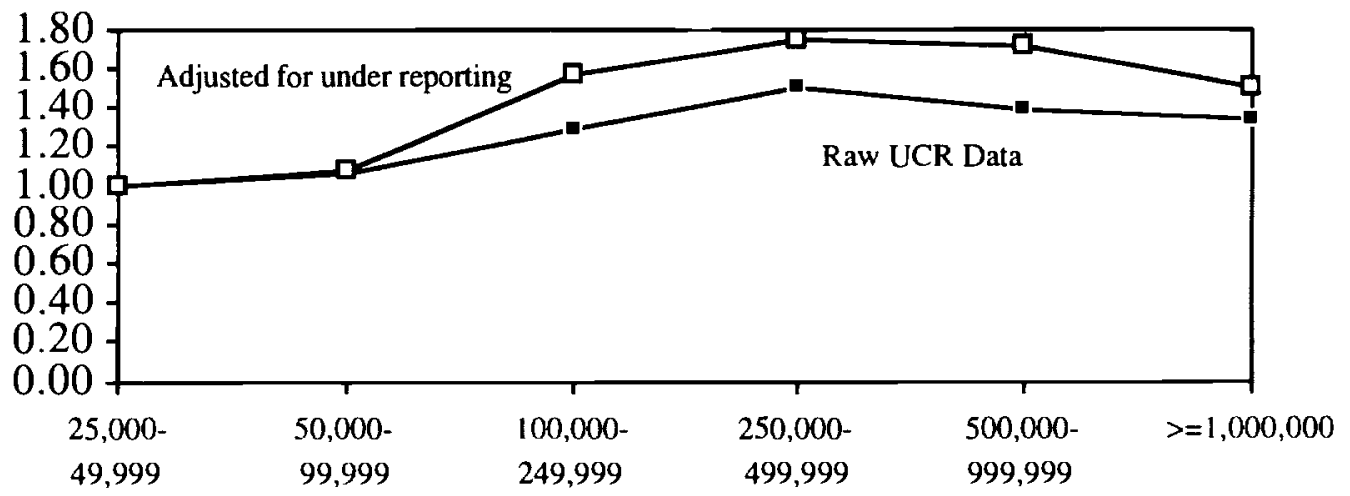

City Population

Arrests/Crime Normalized

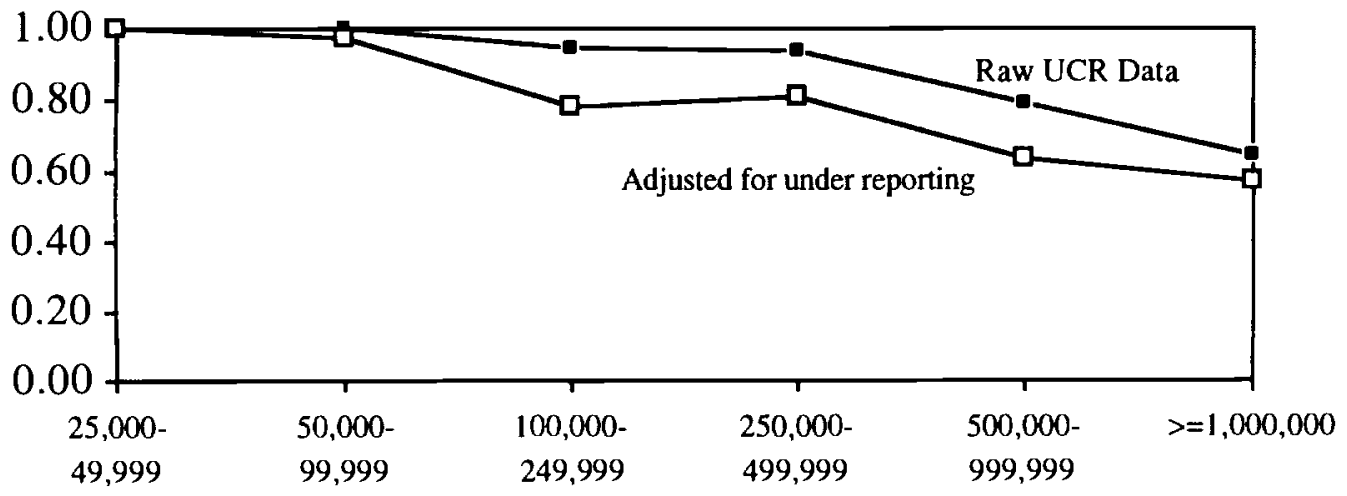

City Population 


\section{Figure 5}

\section{Crimes/ Capita}

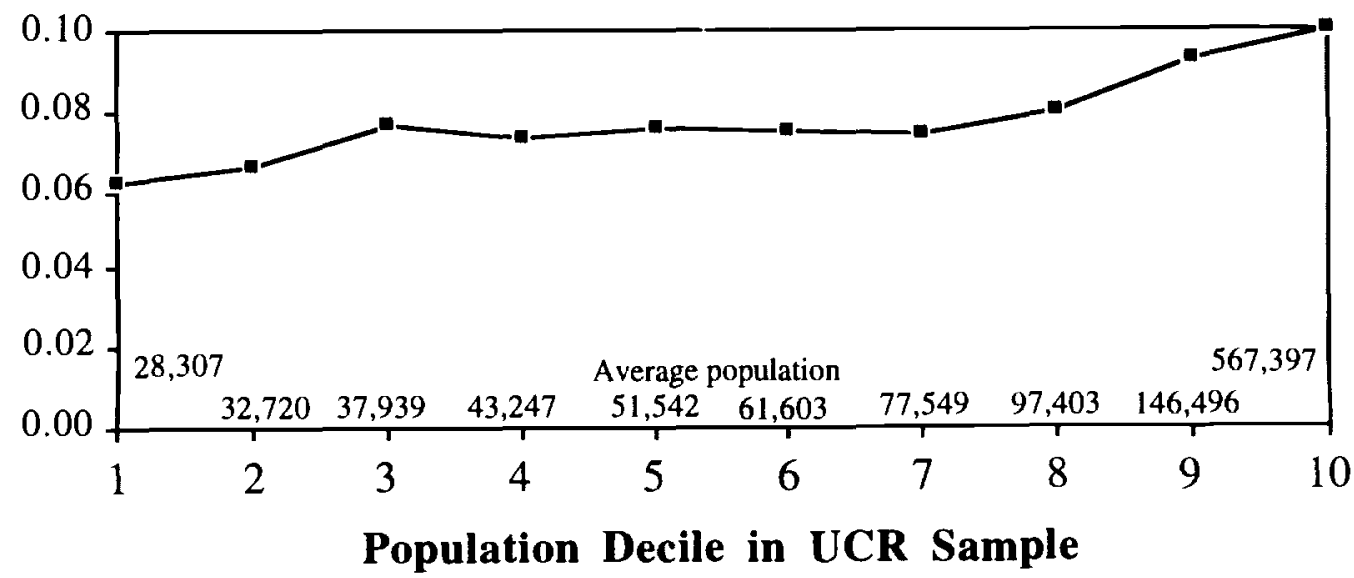

Arrests / Crime

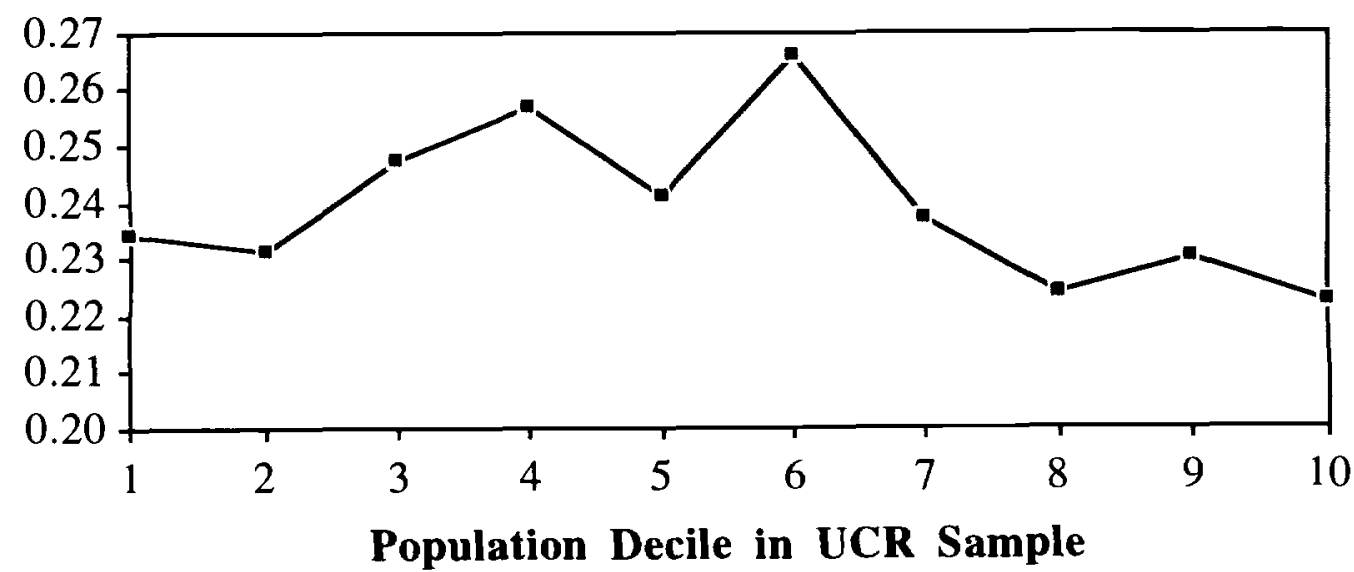

Value Per Crime

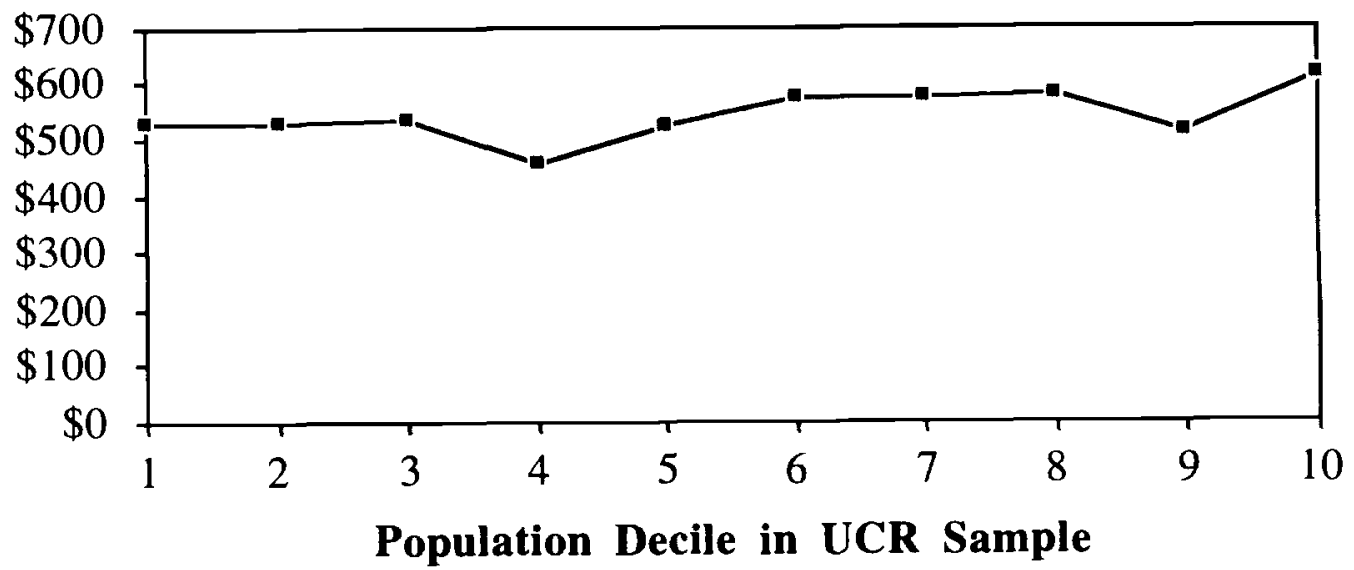

